Universidade de São Paulo - USP

Faculdade de Filosofia Ciências e Letras de Ribeirão Preto

Departamento de Física e Matemática

Programa de Pós - Graduação em Física Aplicada a Medicina e Biologia

\title{
DESENVOLVIMENTO DE UM SISTEMA AUTOMATIZADO EM LÂMPADA DE FENDA PARA MEDIDAS CERATOMÉTRICAS
}

\section{RENATO COELHO}

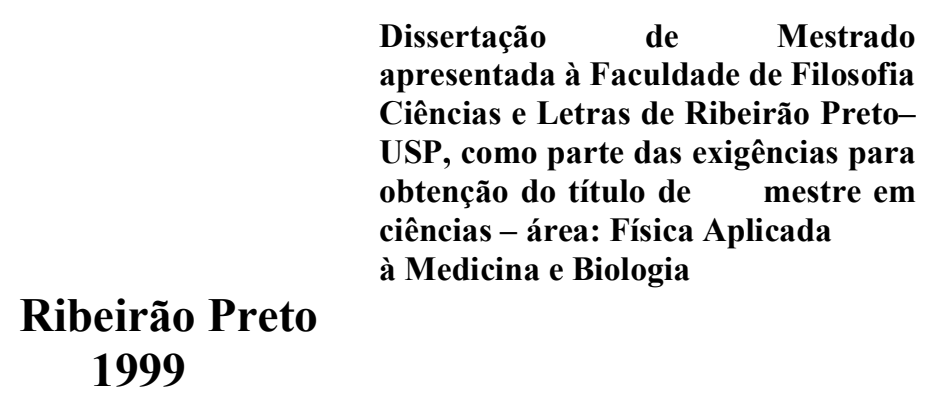


Universidade de São Paulo - USP

Faculdade de Filosofia Ciências e Letras de Ribeirão Preto

Departamento de Física e Matemática

Programa de Pós - Graduação em Física Aplicada a Medicina e Biologia

\title{
DESENVOLVIMENTO DE UM SISTEMA AUTOMATIZADO EM LÂMPADA DE FENDA PARA MEDIDAS CERATOMÉTRICAS
}

\author{
RENATO COELHO
}

Orientadora: Profa. Dra. Liliane Ventura

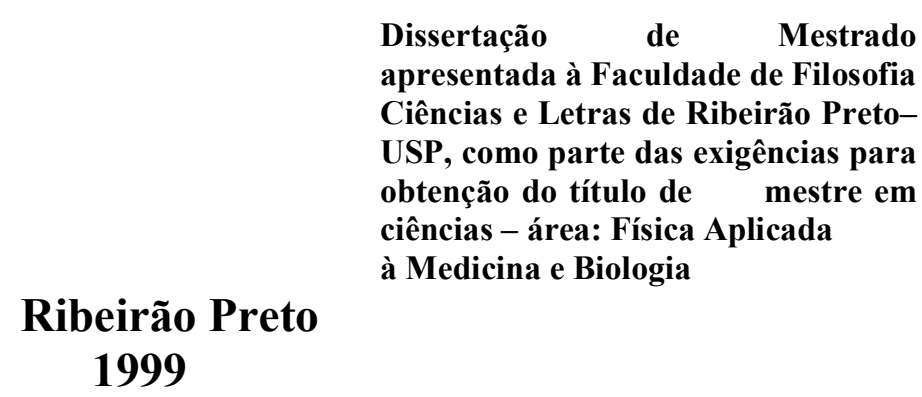




\section{Coelho, Renato}

Desenvolvimento de um sistema automatizado em lâmpada de fenda para medidas ceratométricas/Renato Coelho. - Ribeirão Preto 1999.

Dissertação (Mestrado) - Instituto de Física e Matemática de Ribeirão Preto,1999.

Orientadora: Prof. Dra. Liliane Ventura

1.Oftalmologia. 2.Engenharia Biomédica. 
"Todo aquele, pois que houve estas minhas palavras e as pratica, será comparado a um homem prudente, que edificou sua casa sobre a rocha; e caiu a chuva, transbordaram os rios, sopraram os ventos e deram com impeto contra aquela casa, que não caiu, porque fora edificada sobre a rocha.

E todo aquele que ouve estas minhas palavras e não as pratica, será comparado a um homem insensato, que edificou a sua casa sobre a areia; $e$ caiu a chuva, transbordaram os rios, sopraram os ventos e deram com ímpeto contra aquela casa, e ela desabou, sendo grande a sua ruína.

Quando Jesus acabou de proferir estas palavras, estavam as multidões maravilhadas da sua doutrina; porque ele as ensinava como quem tem autoridade, e não como os escribas. 
À Glória de Deus 


\section{Agradecimentos}

Agradeço primeiro a Deus pelas suas ricas misericórdias derramadas sobre a minha vida.

Gostaria de agradecer também de modo muito especial à minha família; a minha querida MÃEZONA pelas orações, pelos conselhos, pelo empenho, pelo estímulo e o grande amor dados a mim não somente nestes momentos, mas em toda as horas de minha vida ( Olha aí mãezona, nem a distância foi capaz de diminuir esse amor!). Valeu também Cacá, Sula e Lú, vocês que foram e são muito mais do que irmãos para mim. À minha super tia Salet e minha super vó pela força e confiança que depositaram em mim.

Jamais poderia deixar de agradecer também à minha orientadora Dra. Liliane Ventura Schiabel pela paciência, responsabilidade, perseverança e dedicação a este trabalho e à minha pessoa. Valeu Li! Se não fosse você esse trabalho seria ainda só um projeto. Obrigado por alimentar a minha esperança em continuar até o fim.

Aqui vai também um grande agradecimento ao André Messias do LFO, que muitíssimo me auxiliou neste trabalho.

Quero aproveitar também e agradecer aos meus colegas e amigos, a todos estes que de uma forma ou de outra me ajudaram e estiveram juntos comigo nesta “batalha', e que também me incentivaram e me alegraram com suas companhias. Aos da "terrinha": Roosevelt, Sauli e Ulisses ( em ordem alfabética para não magoar ninguém ) pela amizade e todas as horas em que passamos juntos. Aos amigos e camaradas do IFSC, Arilson, Mary, Dudu, Nara e Luciara, pela alegria que suas amizades despertam em mim.

Um grande abraço ao pessoal do LFO ( Lab. Física Oftálmica), ao Caio, César, Flávio, Paulo, Josemilson, a Sabrina, ao Yah, a esse grupo inesquecível meus calorosos abraços.

Ao Alexandre, ao Cláudio, a Márcia, ao Sidney, à Estela e a Renata, essa gente finíssima do Banco de Olhos do H.C. de Ribeirão um abração. 
A todo pessoal do DFM (não vai ser fácil lembrar o nome de todo mundo!): Martin, Paty, Ivan Pisa, Ivan Igarash, Dráulio, Ângela, Tigrão, Éder, Adilton, Dráulio, Marcelo Leal, Marcelo Rodrigues, André Domingos, Gilberto, Cassiana, Vanderlei, Claudinha, Murta, Renato Glauco, Pablo, Felipe, Jô, Flávia, Túlio, Roberto, Maurício...um abração a todos vocês, sempre hei de lembrar-me de cada um.

Também aos professores do DFM, Baffa, Graeff, Rodas, Drugo, Pelá e também aos demais, muitíssimo obrigado por tudo mesmo.

Aos prodigiosos técnicos do DFM que tanto me auxiliaram neste trabalho. Meus sinceros agradecimentos, ao Serginho, Élcio, Eldereis e ao Liander e em especial ao grande técnico e amigo Aziane, pela confecção de cada peça utlizada neste projeto e também pelas valiosas sugestões e idéias a este trabalho.

Também aqui vai um abraço as amáveis e eficientes secretárias do DFM, à Sônia, Rosângela e Gisele.

A todo pessoal do ambulatório da Oftalmo, médicos, enfermeiros e demais funcionários que sempre estiveram pertinho da gente durante esse trabalho, aqui vai meu reconhecimento.

Aos meus "quase irmãos" da Casa do Pós-Graduando 13 que dividiram não somente o mesmo teto que eu, mas também toda a alegria e fraternidade vividas nesse intenso e inesquecível momento de nossas vidas. Um abração bem forte ao Jordan, ao Arthur e ao Arthuzão, ao Roberto, ao Júnior, a Cris e o André, ao Chico, ao ilustre hóspede Pitágoras, ao Jesus, a Sandra a Roxana, a Kátia, a Dulce, a Val, ao Samuel, ao Pablo (de novo!) ao Sauli(de novo!).

Agradeço também ao Júlio do DFM que sempre nos auxiliou com seus serviços junto à secretaria e também pelo cuidado com as minhas correspondências.

Ao pessoal da limpeza do DFM, que sempre deixou tudo bem limpinho para trabalharmos com mais gana e disposição, e também ao pessoal da vigilância, que sempre cuidaram da segurança nossa e de todos os equipamentos do prédio. Às 
cozinheiras e funcionários do Refa's que prestaram grandes e estratégicos serviços aos nossos estômagos.

A todos os funcionários da Biblioteca Central da USP de Ribeirão e também aos da biblioteca da Física de São Carlos pelos serviços de auxílio referente às literaturas usadas neste trabalho. E também ao pessoal da oficina de ótica da USP de São Carlos pela fabricação do filtro de I.V. e ao pessoal da Laboratório de Ensino do Departamento de Física da USP de São Carlos pelo empréstimo do retículo de calibração que foi fundamental a este trabalho. Ao pessoal da Xerox da Biblioteca pela rapidez e qualidade dos serviços.

Ao pessoal da KOM LUX, empresa de fabricação de fibras óticas de Campinas pela qualidade dos serviços prestados.

Também aos meus amados e queridos irmãos de minha igreja, que estiveram sempre comigo, me apoiaram e oraram por minha vida também. Ao meu amado Pr. Narciso do Carmo da Fé e sua amada família meus agradecimentos especiais.

Por fim agradeço `a Capes pelo apoio financeiro. 


\section{Resumo}

Com o intuito de se obter um sistema de ceratometria automático e a baixo custo, desenvolveu-se neste trabalho um sistema ótico e informatizado acoplado à Lâmpada de Fenda.

A Lâmpada de Fenda é um biomicroscópio ocular de ampla aplicação na Oftalmologia e por sua característica de possuir em parte do caminho ótico da luz, feixes paralelos, permite a introdução de componentes óticos sem alterar a imagem observada nas oculares do sistema.

O sistema consiste na projeção de um anel luminoso na córnea do paciente e a análise da deformação sofrida por esta mira para se obter os raios de maior e menor curvatura, bem como o eixo associado a estes raios. A imagem refletida do anel é captada por lentes, prismas e íris adaptados a um divisor de feixes, que está acoplado à Lâmpada de Fenda. Então, esta imagem é captada por um detector do tipo CCD e enviada a um microcomputador do tipo PC, via uma placa de captura comercial.

Um software dedicado ao sistema foi desenvolvido no Laboratório de Física Oftálmica FMRP/USP, e realiza a análise da deformação destes anéis fornecendo assim, a ceratometria da córnea submetida ao exame.

Ainda, através de uma combinação ótica, é possível projetarmos dois anéis adicionais para análise em outras regiões da córnea, em que os sistemas comerciais não permitem. Desta forma, o clínico pode comparar o comportamento dos raios de curvatura da córnea naquelas regiões, com gráficos inseridos no programa de astigmatismos regulares descritos pelos raios fornecidos.

Medidas de astigmatismos irregulares são possíveis com o sistema desenvolvido.

O sistema é de fácil manuseio e a interface do software é bastante amigável com o usuário. Medidas em pacientes voluntários foram realizadas e os resultados apresentados pelo sistema para a projeção da mira padrão estão em concordância com sistemas comerciais automatizados e manuais respectivamente em 1,653\% e 2,363\% para os valores dos raios e $4,159 \%$, e 7,346\% para os ângulos do astigmatismo. 


\section{Abstract}

We have developed an automatic optical system attached to the Slit Lamp in order to provide automatic keratometry at low cost.

The Slit Lamp is a biomicrocope widely used in Ophthalmology and some of them have a particular feature of providing parallel rays in part of its optical path, which allows introducing some optical components without disturbing the image observed at the eyepieces.

The system consists of projecting a light ring as a target at the patient's cornea and the analysis of the deformation of the target in order to obtain the radius of curvature as well as the axis of the associated astigmatism.

The reflected image of the target is captured by lenses, prisms and pin-holes attached to a beam-splitter that is part of the Slit Lamp. The image is then captured by a CCD detector and it's displayed in a PC monitor via a commercial frame grabber.

A dedicated software has been developed in the Laboratório de Física Oftálmica FMRP/USP and it performs the analysis of the reflected target providing the corneal keratotomy.

Also, using na optical combination, it's possible to project at the cornea, two additional targets that are not avariable in commercial systems. Hence the clinician is able to compare the behavior at the cornea curvature radio in these regions with a graphical analysis of regular astigmatism that na provided by the software.

Irregular astigmatism's measurements are possible in the developed system.

The system is easy to use and it has a friendly software interface for the user.

Measurements in volunteer patients have beem made and the results that were obtained are provided by comercial automatic $1,653 \%$ and manual $2,363 \%$ systems. 


\section{Sumário}

Prefácio 1

Introdução 3

CAPÍTULO I - O Olho Humano

1.0 O Olho Humano 5

1.1 A Córnea _ _ 8

1.2 A Topografia da Córnea___ 11

1.3 Defeitos Oculares Astigmatismo___ 12

\section{CAPÍTULO II- O Astigmatismo}

2.0- Introdução 14

2.1.Tipos de Astigmatismo 16

2.2 Sintomas 17

2.3 Codição Ótica 19

2.4 Círculo de Menor Confusão 21

2.5 Algumas Propriedades dos Cilindros 23

2.6 O Ceratocone 23

2.7 Correção Ótica das Ametropias 24

2.8 Astigmatismo-Formalismo Matemático 26

\section{CAPÍTULOIII- O Ceratômetro Convencional}

3.0 Introdução 32 
3.1 Teoria e Funcionamento

3.2 Ceratômetro de Javal-Schiotz 42

3.3 Ceratômetro de Baush e Lomb 48

\section{CAPÍTULO IV. A Lâmpada de Fenda}

4.0 Introdução 51

4.1 O Biomicroscópio 52

4.2 Princípio de Funcionamento do Biomicroscópio 54

4.3 Mudança de Aumento Galileana 55

4.4 Resolução 57

4.5 Brilho da Imagem 59

4.6 Profundidade de Campo 59

4.7 Sistema de Zoom 60

4.8 Sistema de Iluminação 60

4.9 Esquema Geral de Uma Lâmpada de Fenda com Telescópio de Galileo 62

\section{CAPÍTULO V - Materiais e Métodos}

5.0 Introdução 64

5.1 O Sistema Ótico 66

5.1.1 Anel Luminoso 66

5.1.2 O Separador de Feixes e o Adaptador Ótico para CCD 67 
5.1.3 O Acolplador de Lentes 67

5.2 Sistema de Detecção 70

5.2.1 A Câmara CCD 70

5.2.2 A Placa digitalizadora de Imagem 71

\section{CAPÍTULO VI- Fundamentos Teóricos}

6.0 Calibrando o Sistema 73

6.1 Modelo Esférico 74

CAPÍTULO VII- O "Software” Desenvolvido 77

7.0 Característica Básica 77

7.1 Acessórios 83

CAPÍTULO VIII - O Sistema de Calibração

8.0 Apresentação 84

CAPÍTULO IX-Resultados 90

CAPÍTULO X - Discussão 93

CAPÍTULO XI - Conclusão 95

Bibliografia 95

Apêndice I - Miopia e Hipermetropia I

Apêndice II - O Modelo Esférico XI 


\section{Lista de Figuras}

\section{Capitulo I}

Figura 1.0: O olho e suas partes constituintes

Figura 1.1: Divisão da superfície da córnea

Figura 1.2: A córnea em camadas

Figura 1.3: O olho reduzido

Figura 1.4: Ametropias oculares

\section{Capítulo II}

Figura 2.0: Classificação do astigmatismo regular

Figura 2.1:Formação de imagem no astigmatismo

Figura 2.2: Superfícies esféricas e tóricas

Figura 2.3: Formação de imagem em superfície cilíndrica

Figura 2.4: Círculo de menor confusão

Figura 2.5: Olho com ceratocone

Figura 2.6: Ceratocone

Figura 2.7: Correção ótica de ametropia

Figura 2.8: Representação da função seno

Figura 2.9:Representação da função astigmatismo

Figura 2.10:Representação esquemática do astigmatismo

\section{Capítulo III}

Figura 3.0: Prisma de Helmholtz

Figura 3.1: Princípio do ceratômetro: objeto constante

Figura 3.2: Princípio do ceratômetro: imagem constante

Figura 3.3: Princípio do ceratômetro

\section{Capítulo IV}

Figura 4.0:Microscópio composto

Figura 4.1: Esquema de um microscópio composto

Figura 4.2:Microscópio composto com prisma de Porro

Figura 4.3: Telescópio de Galileo

Figura 4.4: Iluminação de Vogt

Figura 4.5: Desenho esquemático de Lâmpada de Fenda

Figura 4.6: Lâmpadas de Fenda: a)Zeis, b) Haag Streit 


\section{Capitulo V}

Figura 5.0: Lâmpada de Fenda TOPCON SL-7E

Figura 5.1: Dezsenho do ceratômetro automatizado montado em LF

Figura 5.2: Foto das partes do sistema

Figura 5.3: (a) Adaptador ótico para imagem em LF no CCD ; (b) Separador de feixes

Figura 5.4: Detalhes do acoplamento dos: divisor de feixes, adaptador ótico, acoplador de lentes e câmera

Figura 5.5:Acoplador de lentes

Figura 5.6:Câmara CCD PHILCO HITACHI KPC-550

Figura 5.7: Imagem do reflexo do anel na córnea vista no monitor do PC

\section{Capitulo V}

Figura 6.0: Modelo Esférico

\section{Capitulo VII}

Figura 7.1: Esquema geral do Software

Figura 7.2: Tela pricipal do software

Figura 7.3: Tela de resultados

Figura 7.4:Tela de resultados e análise gráficva

\section{Capitulo VIII}

Figura 8.1: Esferas de calibração

Figura 8.2: Foto do sistema montado em LF 


\section{Apêndice I}

FiguraA1.1: Ametropias Oculares: (a) emetropia; (b) miopia; (c) hipermetropia.

FiguraA1.2: Representação de quatro raios de luz incidentes num olho astigmático.

Figura A1.3: Correção através de lentes para a: (a) hipermetropia; (b) miopia.

\section{Apêndice II}

Fig.A2.1 - Esquematização do caminho óptico dos raios de luz para dedução da equação com aproximação "fina" para o modelo esférico.

\section{Lista de Tabelas}

\section{Capitulo I}

Tabela 1.0 - Índices de refração das partes óticas constituintes do olho humano ${ }^{[2]}$.

\section{Capítulo IIII}

Tabela 3.0 - Tabela de Gullstrand e Listing

\section{Capitulo V}

Tabela 5.1: Características do detector CCD Hitachi KPC-550. 


\section{Capitulo VIII}

Tabela 8.1: Erros obtidos para focalização em Lâmpada de fenda para aumentos variados

\section{Capítulo VIII}

Tabela 9.1 - Valores dos Raios de Curvatura Corneanos de Pacientes Voluntários

Obtidos em Três Sistemas - Comerciais: Topcon e Baush Lomb; Nosso Sistema (NS). O raios maiores e

menores referem-se aos raios de curvatura dos eixos principais do astigmatismo corneano.

Tabela 9.2 - Valores, em porcentagem, de discrepância nas medidas entre o nosso sistema (NS) e os sistemas comerciais automático (Topcon) e manual (Baush-Lomb) 


\section{Prefácio}

“Fiat Lux ”... ${ }^{[1]}$

O interesse e a curiosidade do homem pela luz remonta desde o início da nossa civilização. Já na Grécia antiga os filósofos da época indagavam a respeito da visualização dos objetos e sobre a natureza da luz.

Platão acreditava que nossos olhos emitiam pequenas partículas, que ao atingirem os objetos, os tornavam visíveis. Já Aristóteles considerava a luz como um fluído material que se propagava entre o olho e o objeto visto.

Durante séculos vigoraram as idéias aristotélicas e também as platônicas. Entretanto estas mesmas idéias não foram capazes de explicar todos os fenômenos que iam sendo observados e a luz continuava a intrigar a humanidade.

Mas foi Sir Isaac Newton já no séc. XVIII quem criou a chamada teoria corpuscular da luz, onde conseguiu explicar a reflexão e também a refração, ao considerar a luz como formada por um conjunto de partículas corpusculares.

Logo mais tarde surge a teoria ondulatória da luz, que diferentemente da teoria newtoniana, considerava a luz como uma onda. Tal teoria foi grandemente difundida por Christian Huygens e Robert Hooke, que explicaram a reflexão e a refração da luz usando o conceito da propagação ondulatória, mas durante um bom tempo continuou sendo aceita a chamada teoria corpuscular, devido às objeções e relutâncias de Newton e seus seguidores.

Mas o grande "xeque-mate" da teoria ondulatória da luz veio em $1801 \mathrm{com}$ Thomas Young e depois com Fresnel ( 1788-1827 ) que através de experiências em difração e interferências de ondas, conseguiu construir todo o fundamento matemático para a teoria ondulatória. E foi Jean Focoult que em 1850 mediu pela primeira vez a velocidade da luz na água e mostrou que era menor que no ar, combatendo assim a teoria corpuscular de Newton, pois a teoria newtoniana supunha 
em suas demonstrações para explicar a refração, que a luz ao atravessar a água ou o vidro, possuía velocidade maior que a do ar.

Depois vieram James C. Maxwell com a teoria matemática do eletromagnetismo, que também previa a existência de ondas eletromagnéticas, que foram detectadas por Hertz pela primeira vez com a utilização de circuitos elétricos.

Mas a briga entre a teoria corpuscular de Newton e a teoria ondulatória de Young e Fresnel acabou dando em nada, pois apesar da teoria ondulatória da luz ser capaz de explicar muitos fenômenos óticos, não é capaz de explicar a todos eles, como por exemplo o efeito fotoelétrico demonstrado por Einstein, onde toda teoria se baseia no modelo corpuscular da luz. Apartir de então surge no cenário a chamada dualidade da luz, onde a natureza onda-partícula coexistem. 


\section{Introdução}

"Nós não somos simplesmente passivos às impressões que nos estimulam, mas nós as observamos" (Herman von Helmholtz)

A ceratometria da córnea consiste na medição dos raios de curvatura da mesma. A utilidade de tais medidas é bastante ampla no dia a dia de um médico oftalmologista. Um bom planejamento de um transplante corneano, por exemplo, depende essencialmente de uma ceratometria prévia. Também na adaptação de lentes de contato, na avaliação do astigmatismo da córnea e na detecção do ceratocone se constatam a relevante importância de medidas ceratométricas.

Os ceratômetros existentes hoje no Brasil são em sua maioria aparelhos importados, de alto custo e de uso exclusivo em medidas de raios de curvatura. Existe atualmente no mercado uma enorme variedade de sistemas de ceratometria automatizada porém nenhum deles acoplados à lâmpada de fenda. Vê-se assim a grande contribuição para a comunidade oftalmológica brasileira a construção de um sistema ceratométrico automático acoplado diretamente a uma lâmpada de fenda, contribuindo para uma melhor acessibilidade de dados por parte do médico, também ressalta-se aqui a grande importância aqui em se desenvolver tecnologia nacional e também uma relevante diminuição de custos, já que os ceratômetros convencionais em sua maioria são importados, com o preço variando em cerca de $\$ 12.000$.

O sistema de ceratometria automatizado consiste na projeção de uma mira circular na córnea e através de cálculos puramente geométricos, determina-se o raio de curvatura da região analisada. Neste sistema há a projeção de 3 anéis concêntricos e não-simultâneos para uma análise não somente da região central, mas também da região periférica da córnea. Sendo tais características uma grande vantagem sobre os ceratômetros convencionais, já que os mesmos utilizam tão somente a projeção de um único anel e também a não simultaneidade da projeção 
dos anéis torna o processamento e os cálculos mais simples e rápidos, além do que fornece maior precisão aos resultados obtidos. 


\section{Capítulo 1 - O Olho Humano}

\section{0 - O Olho Humano}

O olho humano (figura 1.0) é constituído por um complexo sistema ótico dividido em seis partes físicas fundamentais ${ }^{[2]}$ : a refração, que ocorre na córnea (a maior parte da refração ocorre neste componente ótico - 3/4 da refração total da luz, que entra no olho), no cristalino, no humor aquoso e no humor vítreo também; a auto-focalização, realizada pelos músculos ciliares e o cristalino; o controle da luminosidade interna realizada pela íris e pupila; a detecção, feita pela retina (cones e bastonetes); a transmissão da informação ao cérebro, feita pelo nervo e as vias ópticas; e a refrigeração da retina realizada pela coróide.

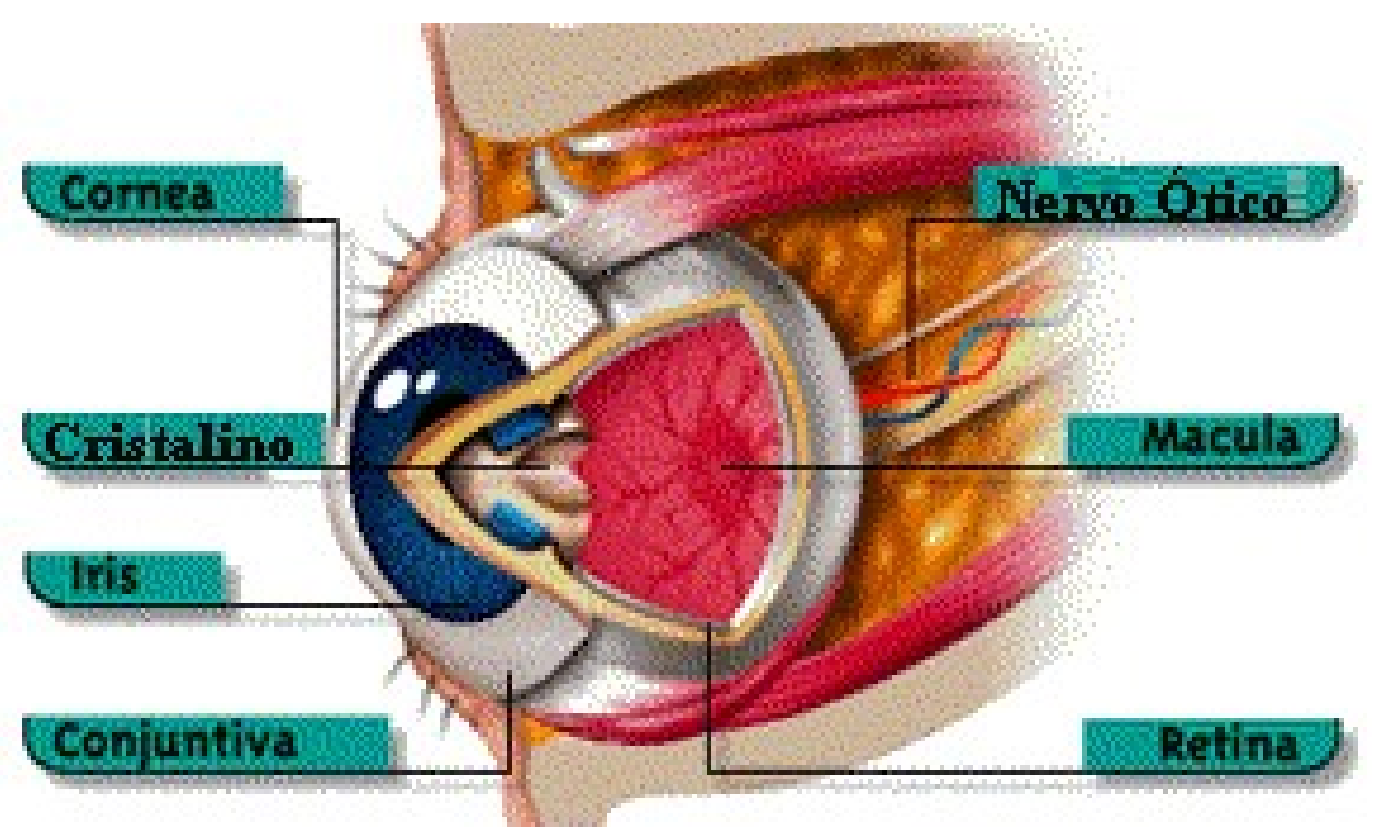

Fig. 1.0 - O olho e suas partes constituintes 
A parte mais externa do olho é a córnea, um tecido transparente e curvo que por sua vez é banhado externamente por uma fina película lacrimal. A córnea posssui um índice de refração de 1,376 e espessura de $0,480 \mathrm{~mm}$. O raio de curvatura externo é de $7,8 \mathrm{~mm}$ aproximadamente, variando de pessoa para pessoa, mas geralmente para olhos normais o mesmo varia entre 7 a $8 \mathrm{~mm}^{[3]}$.

A face posterior da córnea possui um raio de curvatura que varia entre 6,8 a $6,22 \mathrm{~mm}$. Logo a face anterior tem um raio maior que a interna, cujo valor varia entre 7 a $8 \mathrm{~mm}$, observa-se então que a córnea equivale a uma lente curva negativa.

Sendo a espessura muito pequena, podemos admitir, para efeitos de cálculo, que as faces são paralelas.[4]

Os raios que incidem na córnea sofrem um grande desvio devido basicamente à sua curvatura $(42,95$ di de poder de refração) e também à relativa diferença de seu índice de refração e o ar. A córnea, na verdade, não possui uma forma perfeitamente esférica, possui um formato elipsóide, onde somente na região central, denominada zona óptica central de aproximadamente 4,0mm (figura 1.1), é onde se pode averiguar um formato aproximadamente esférico.

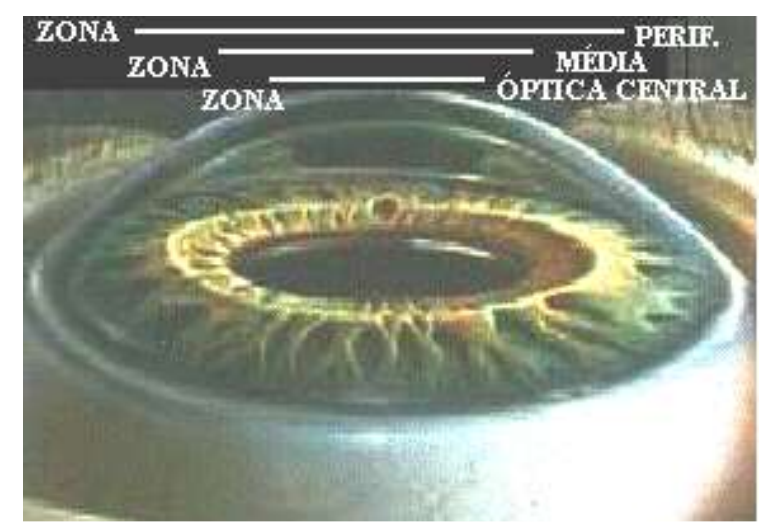

Fig. 1.1 - Divisão da superfície corneana em zonas topográficas

Atrás da córnea encontramos a região denominada humor aquoso, cujo índice de refração é aproximadamente igual ao da água.

A íris se localiza na região central do olho, possui uma forma circular. $\mathrm{O}$ diâmetro desta abertura é variável graças a ação dos músculos ciliares, onde a ação involuntária, permite regular a quantidade de luz que deve penetrar no olho. A íris 
funciona como um diafragma, sendo capaz de limitar os raios centrais emergentes no olho para produzir imagens mais perfeitas. Pupila é o nome dado a esta abertura regulável.

O cristalino é na verdade uma lente biconvexa de 9 a $10 \mathrm{~mm}$ de diâmetro e $4 \mathrm{~mm}$ de espessura, com sua face anterior de menor curvatura do que a posterior, sendo constituído por fibras cristalinas concêntricas e sobrepostas em lamelas como em uma "cebola". Com o pasar do tempo o cristalino pode perder a sua elasticidade e transparência, tornando-se opaco.

O cristalino possui um índice de refração variável da periferia ao centro, compreendido entre 1,406 e 1,455 .

O cristalino pode modificar o raio de curvatura de suas faces graças aos chamados músculos ciliares, mecanismo esse denominado acomodação.

Posteriormente ao cristalino, encontra-se uma substância transparente, com o aspecto parecido com a clara de um ovo, chamada humor vitreo.

A Tabela 1.0 abaixo traz os índices de refração de cada componente ótico ocular.

Tabela 1.0 - Índices de refração das partes óticas constituintes do olho humano ${ }^{[2]}$.

Componente Ótico Indice de Refração

\section{Córnea}

Humor Aquoso

Humor vítreo

Cristalino
1.376

1.336

1.336

1.406

A coróide é a região responsável pela irrigação sangüinea do olho, funciona como uma espécie de "radiador" do olho, mantendo a temperatura sempre estável. 
Na região mais posterior do olho encontramos a chamada retina, constituída por fibras nervosas capazes de detectar a imagem sobre ela projetada. Ela é formada por duas ramificações do nervo ótico, constituindo a parte fotossensível do olho. É composta por elementos sensíveis chamados de cones (responsáveis pela detecção de cores) e bastonetes (responsáveis pela detecção de tonalidades). A cada cone corresponde a uma única fibra, por outro lado, muitos bastonetes podem estar ligados a uma única fibra. Por isso resulta que os cones são mais sensíveis que os bastonetes.

As partes constituintes da retina, não são igualmente sensíveis. Assim sendo existem duas zonas de importância, uma delas é o chamado “ponto cego”, que é a região por onde penetra o nervo ótico. A outra região é a mácula, que possui uma depressão em seu centro: a fóvea central, ponto de sensibilidade máxima. $\mathrm{Na}$ fóvea central a retina é bastante delgada e se caracteriza por possuir exclusivamente cones.

\subsection{A córnea}

A córnea é a parte mais externa do olho. É um tecido transparente e avascular. A qualidade da visão está intimamente relacionada com as condições físicas deste tecido. Possui um índice de refração de aproximadamente 1,376, espessura média de $0,480 \mathrm{~mm}$ e uma vergência de 42,95 di. Tem um formato de elipsóide, como uma secção de uma bola de futebol americano, com raio médio de 7 a $8 \mathrm{~mm}$ para um olho adulto normal.

Ela possui 6 divisões principais (figura 1.2) ${ }^{[3]}$ : 


\section{Epitélio;}

2. Membrana de Bowmam

3. Substância própria;

4. Membrana Descement;

5. Estroma;

6. Endotélio.

O epitélio é uma camada uniforme (50 a $100 \mu \mathrm{m}$ de espessura), que por sua vez se subdivide em seis camadas formadas por células arredondadas e também poliédricas. A limitação física feita por esta camada constitui uma barreira parcial para a difusão de água e sal para o estroma, que é uma camada subjacente. Grande resistência física é efetuada pelo epitélio.

A membrana de Bowman é uma membrana uniformemente clara, funciona como uma lâmina elástica, com cerca de $10 \mu \mathrm{m}$ de espessura, é uma camada bastante condensada.

A substância própria constitui cerca de $90 \%$ da espessura da córnea e contém duas camadas elásticas, a membrana de Bowmam e a membrana de Descement.

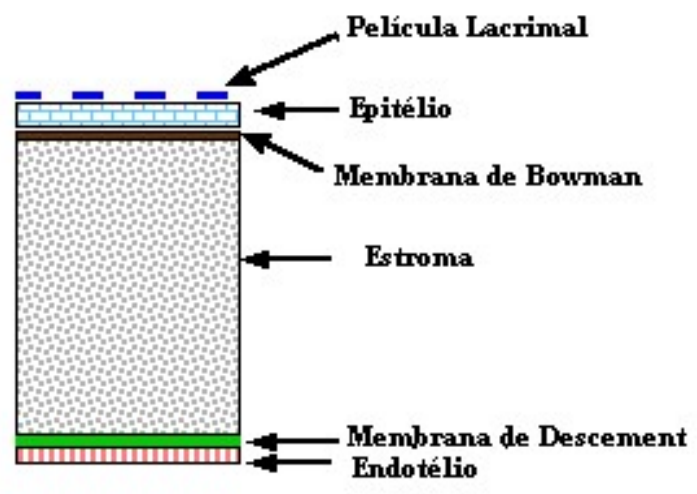


Fig. 1.2 - Córnea dividida em camadas

Já a membrana de Descement, que foi descrita pela primeira vez por Jean Descement em 1758, varia em espessura entre 5 e $7 \mu \mathrm{m}$ no centro para $10 \mu \mathrm{m}$ na periferia. Esta é a quarta camada da córnea e está colada com a substâcia própria posteriormente.

O estroma é a camada mais espessa da córnea, esta relacionada com a nutrição do olho.

Por fim o endotélio que é a camada mais interna da córnea. Ë aqui que se encontram as chamadas células endoteliais que são responsáveis pela

\section{2 - A topografia da córnea}

A córnea possui uma pequena porção central, cujos poderes variam entre $41 \mathrm{e}$ 45dioptrias. Em condições não habituais pode haver um aplainamento de até 37 dioptrias e abaulamentos de até 60 dioptrias. Precisamente, sabe-se que essa zona dita regular, praticamente nunca é esférica, sendo na verdade tórica, tornando assim, diferentes os valores dos meridianos horizontal e vertical.

Pode-se esquematizar a configuração da córnea, onde se tem uma zona chamada de zona negativa, como tendo $34 \mathrm{~mm}$ de diâmetro e sendo regular de 4 a 
$8 \mathrm{~mm}$. Ao redor da zona negativa existe uma outra zona chamada positiva de $1 \mathrm{~mm}$, sendo de 6 a 7 dioptrias mais plana que a anterior.

A medida dos valores da córnea nestas respectivas zonas citadas, é de importância relevante para adaptações adequadas de lentes de contato, que se deslocam e acabam se tornando desconfortáveis ao paciente.

Quando se trabalha com um sistema ótico complexo, o mesmo pode ser aproximado a um sistema simples correspondente, onde continuam válidas as mesmas regras de refração, desde que o sistema esteja centralizado formando um sistema homocêntrico, e o olho satisfaz estas mesmas condições. Portanto, podemos criar um modelo teórico simples representativo do olho, que é o chamado olho reduzido.

Neste modelo o olho é transformado em uma superfície de refração ideal isolada, não acrescentando nenhum erro apreciável às medidas.

Este modelo permite com maior facilidade construir as imagens formadas no olho humano.

Consideramos então uma superfície esférica cujo raio de curvatura é de $5 \mathrm{~mm}$ ( figura 1.3), cujo centro corresponda ao centro óptico ou centro nodal do olho $(\mathrm{N})$. A profundidade total do olho é de $20 \mathrm{~mm}$, que significa que a retina dista $15 \mathrm{~mm}$ do ponto nodal. As imagens se formam na retina e por isso a distância focal do olho equivale a $20 \mathrm{~mm}$ para um objeto que se encontra muito distante. $\mathrm{O}$ ar e o olho possuem índices de refração distintos, respectivamente de 1 (no vácuo) e 1,336. 


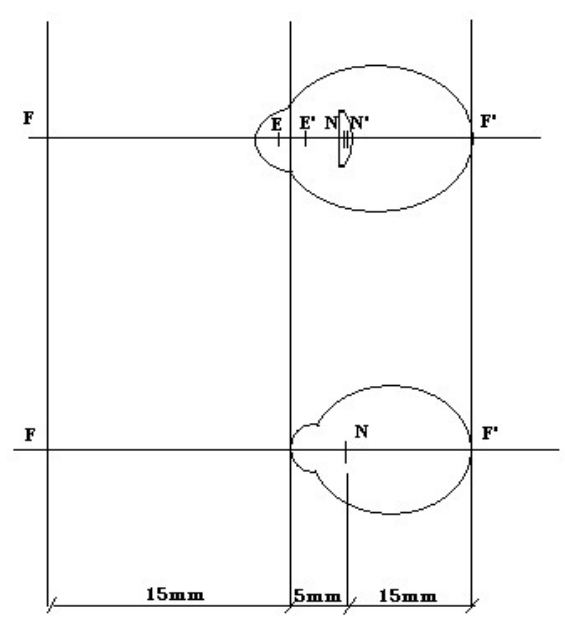

Fig. 1.3-O olho reduzido, representação esquemática

\subsection{Defeitos Oculares}

Quando os feixes de raios paralelos incidem sobre um olho, que encontra-se em estado de repouso (livre da acomodação visual) ${ }^{[2]}$ e são, diz-se que o olho é emétrope.

Devido a desarmonias entre o comprimento axial e o sistema ótico oculares, são gerados os vícios de refração. Quando os feixes se focalizam antes da retina ("olho longo") ou após a retina ("olho curto"), configuram-se miopia e a hipermetropia, respectivamente (figura 1.4). Maiores detalhes sobre estes vícios de refração podem ser encontrados no Apêndice I. 


\section{H E M}

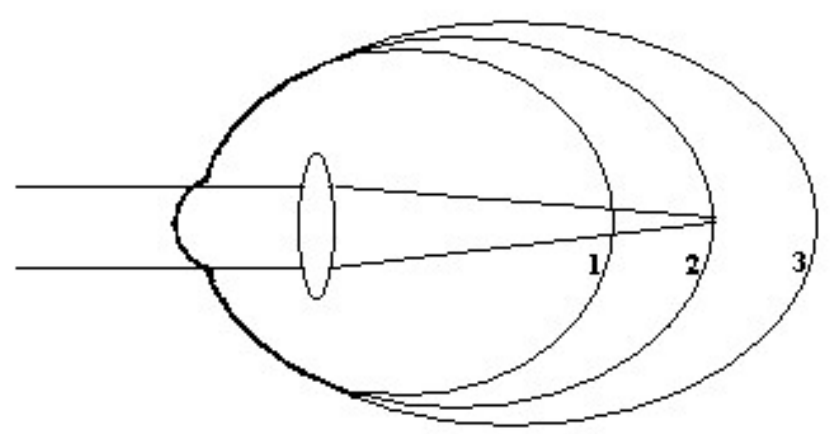

Fig. 1.4-Ametropias oculares: 1- Hipermetropia; 2- Normal (emétrope ); 3 - Miopia

Existe ainda um outro defeito da visão denominado astigmatismo. Devido à sua relevância neste trabalho será tratado detalhadamente no capítulo a seguir. 


\section{Capítulo 2 - O ASTIGMATISMO ${ }^{[5]}$}

\section{0 - Introdução ${ }^{[6]}$}

O astigmatismo ocular vem sendo alvo de estudos há alguns séculos. Em 1727 Sir Isaac Newton fez algumas investigações sobre esta ametropia ocular, sendo ele próprio um astigmático. Já em 1801, Thomas Young foi quem pela primeira vez descreveu e mediu o astigmatismo em seu artigo: 'On the Mechanism of the Eye'. Ele incluiu em sua medidas constantes óticas de seu próprio astigmatismo (astigmata de 1,70di). Ele imergia toda cabeça em água para tentar eliminar a influência da refração da córnea, então ele atribuiu este defeito ao cristalino.

Geoge Biddell Airy (1801-1892 ${ }^{[6]}$ descobriu também, independentemente, o astigmatismo em seu próprio olho em 1827. Airy foi professor de matemática em Cambridge e depois professor de astronomia, continuando seus estudos sobre astigmatismo durante 60 anos. ${ }^{[6]}$

Mas foi Airy (1827), quem pela primeira vez corrigiu este defeito utilizando lentes cilíndricas.

A palavra astigmatismo, terminologia comumente utilizada na oftalmologia, é de origem grega (Alpha=primitivo; Estigma $a$ ponto). Denomina-se astigmatismo corneano a não esfericidade da superfície da córnea, ou seja, a ocorrência de diferentes raios de curvatura entre os diferentes meridianos, o que resulta em diferente poder de refração para cada meridiano analisado. Sendo assim, o olho astigmático refrata a luz em diferentes linhas focais, separadas por uma distância denominada conóide de Sturm. O comprimento deste intervalo compreende o grau do astigmatismo.

O astigmatismo pode ser um erro de curvatura, de centralização ou do índice de refração ${ }^{[5]}$. 


\section{O Astigmatismo}

$\mathrm{O}$ astigmatismo de curvatura, se de um grau mais intenso, tem sua origem mais freqüente na córnea. A anomalia é em geral congênita e as medidas oftalmométricas mostram que a sua ocorrência em pequenos graus é comum. $\mathrm{O}$ erro mais freqüente é aquele em que a curva vertical é maior que a horizontal (aproximadamente 0,25di). Este é conhecido como astigmatismo direto ("a favor da regra"), e é aceito como fisiológico; presumivelmente se deve a uma pressão constante da pálpebra superior sobre o olho. Marin Amat ${ }^{[5]}$ descobriu que, enquanto no nascimento a córnea é normalmente quase esférica, este tipo de astigmatismo está presente em $68 \%$ das crianças aos 4 anos de idade, e em $95 \%$ aos 7 anos. Há evidência de que tende a aumentar em grau muito discreto nos anos seguintes; porém, com a idade, tende a desaparecer ou mesmo tornar-se em astigmatismo inverso ("contra a regra"), com a curvatura vertical menor do que a horizontal.

$\mathrm{O}$ astigmatismo adquirido também se observa com freqüência. Patologia da córnea resulta em sua deformidade; um exemplo extremo disso é observado na córnea cônica, embora as inflamações e as ulcerações tenham o mesmo efeito.

O astigmatismo de curvatura do cristalino também ocorre com grande freqüência. Na grande maioria dos casos, anomalias dessa natureza são pequenas; porém, às vezes, como no lenticone, podem ser acentuadas. Com freqüência, o cristalino é colocado em ligeira obliqüidade ou fora dos planos normais do sistema ótico, e isso, provocando um certo grau de descentralização, produz um astigmatismo correspondente; uma subluxação traumática do cristalino possui resultados semelhantes. Finalmente, um pequeno grau de astigmatismo de índice ocorre na fisiologia do cristalino. Este é, em geral, discreto, e se deve a pequenas desigualdades do índice de refração dos diferentes setores, porém pode ser acentuado, produzindo distorção considerável. 


\section{O Astigmatismo}

\section{1 - TIPOS DE ASTIGMATISMO}

$\mathrm{O}$ astigmatismo em que os dois meridianos principais encontram-se em ângulos retos e que é, portanto, passível de correção, é denominado de regular. Na grande maioria desses casos, os meridianos de maior e menor curvatura estão próximos ou realmente verticais e horizontais ou vice-versa. Caso isso não ocorra desse modo e uma vez que o meridiano maior e o menor estejam em ângulos retos, teremos então um astigmatismo regular que denominamos astigmatismo oblíquo. Quando os eixos não se encontram em ângulos retos, mas são cruzados obliquamente, o sistema ótico é ainda passível de resolução numa combinação esferocilíndrica, e a condição pode ser denominada de astigmatismo bioblíquo; não é de ocorrência muito comum.

Quando existem irregularidades na curvatura dos meridianos de forma que nenhuma figura geométrica adere aos mesmos, a condição é denominada astigmatismo irregular; não permite sua correção adequada por óculos.

\section{ASTIGMATISMO REGULAR}

O astigmatismo regular pode ser classificado da seguinte maneira (figura 2.0):

1. astigmatismo simples, onde um dos focos incide sobre a retina. $\mathrm{O}$ outro foco pode incidir na frente ou atrás da retina, de forma que enquanto um meridiano é emétrope, o outro é hipermétrope ou míope. Estes são, respectivamente, designados de astigmatismo hipermétrope simples e miope simples.

2. astigmatismo composto, onde nenhum dos dois focos localiza-se sobre a retina, porém ambos localizam-se na frente ou atrás dela. O estado da refração é inteiramente hipermétrope ou inteiramente míope. O primeiro é conhecido como astigmatismo hipermétrope composto, e o último como astigmatismo míope composto.

3. astigmatismo misto, onde um foco localiza-se na frente e outro atrás da retina, de forma que a refração é hipermétrope em uma direção e míope na outra.

O tipo habitual fisiológico de astigmatismo, onde a curva vertical é maior do que a horizontal, é denominado de astigmatismo direto ou astigmatismo "com a 


\section{O Astigmatismo}

regra"; em caso inverso, trata-se de um astigmatismo indireto ou astigmatismo "contra a regra".

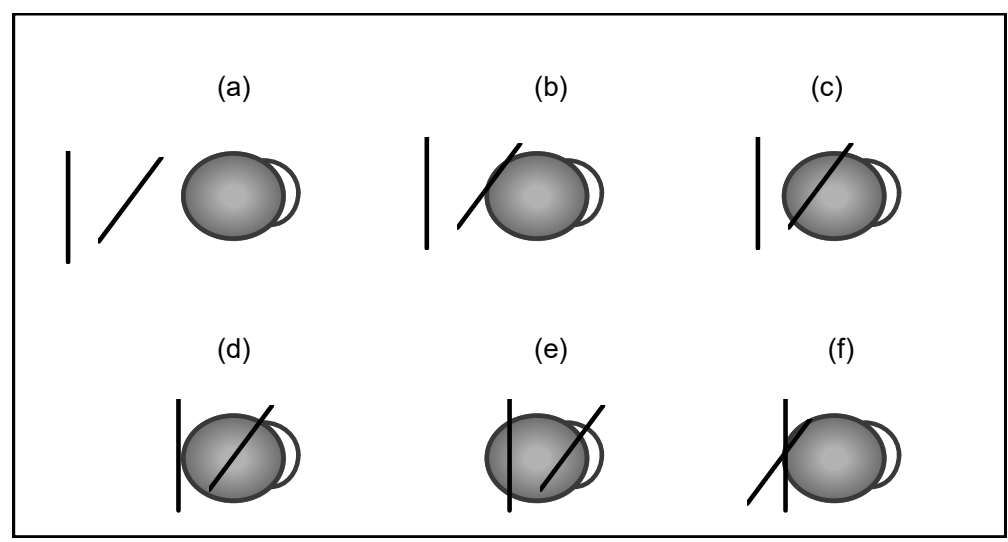

Figura 2.0: Classificação do astigmatismo regular: (a) hipermétrope composto; (b) hipermétrope simples; (c) misto; (d) míope simples; (e) míope composto; (f) sem astigmatismo.

\section{2 - SINTOMAS}

Quando o grau de astigmatismo é apreciável, visto que em nenhuma circunstância o olho é capaz de formar uma imagem nitidamente definida sobre a retina, a diminuição da acuidade visual pode ser bastante considerável. Na tentativa de ver claramente, o paciente tenta focalizar o círculo central de menor confusão (vide item 2.4 - "Círculo de Menor Confusão"). A visão do astigmata mostra peculiaridades outras que a indistinção, a despeito da forma alongada dos círculos de difusão que tem de interpretar. Os círculos tornam-se alongados, acurvados; um ponto de luz aparece borrado; e uma linha, que consiste numa série de pontos, aparece como uma sucessão de linhas fundidas numa imagem borrada.

Imaginemos um indivíduo astigmático focalizando sobre uma linha focal vertical e olhando em duas linhas retas que ficam uma perpendicular à outra (figura 2.1). Podemos imaginar as linhas compostas de um número infinito de pontos, cada um dos quais aparecendo na sua retina como uma linha vertical curta (ou, mais corretamente, uma elipse). A linha horizontal, portanto, aparece como uma série de 


\section{O Astigmatismo}

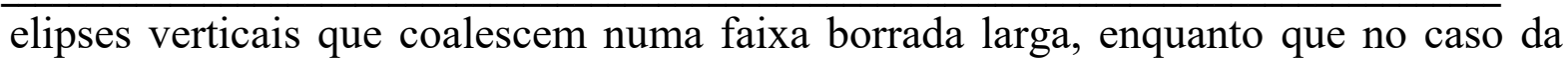
linha vertical, as elipses verticais se sobrepõem, de modo que toda a linha aparece nitidamente definida, somente com a parte mais superior e a mais inferior das elipses constituintes se estendendo além dela, determinando um aspecto borrado e fazendo-a parecer mais longa do que normalmente é. Inversamente, se a linha focal horizontal for focalizada, as linhas verticais tornam-se borradas.

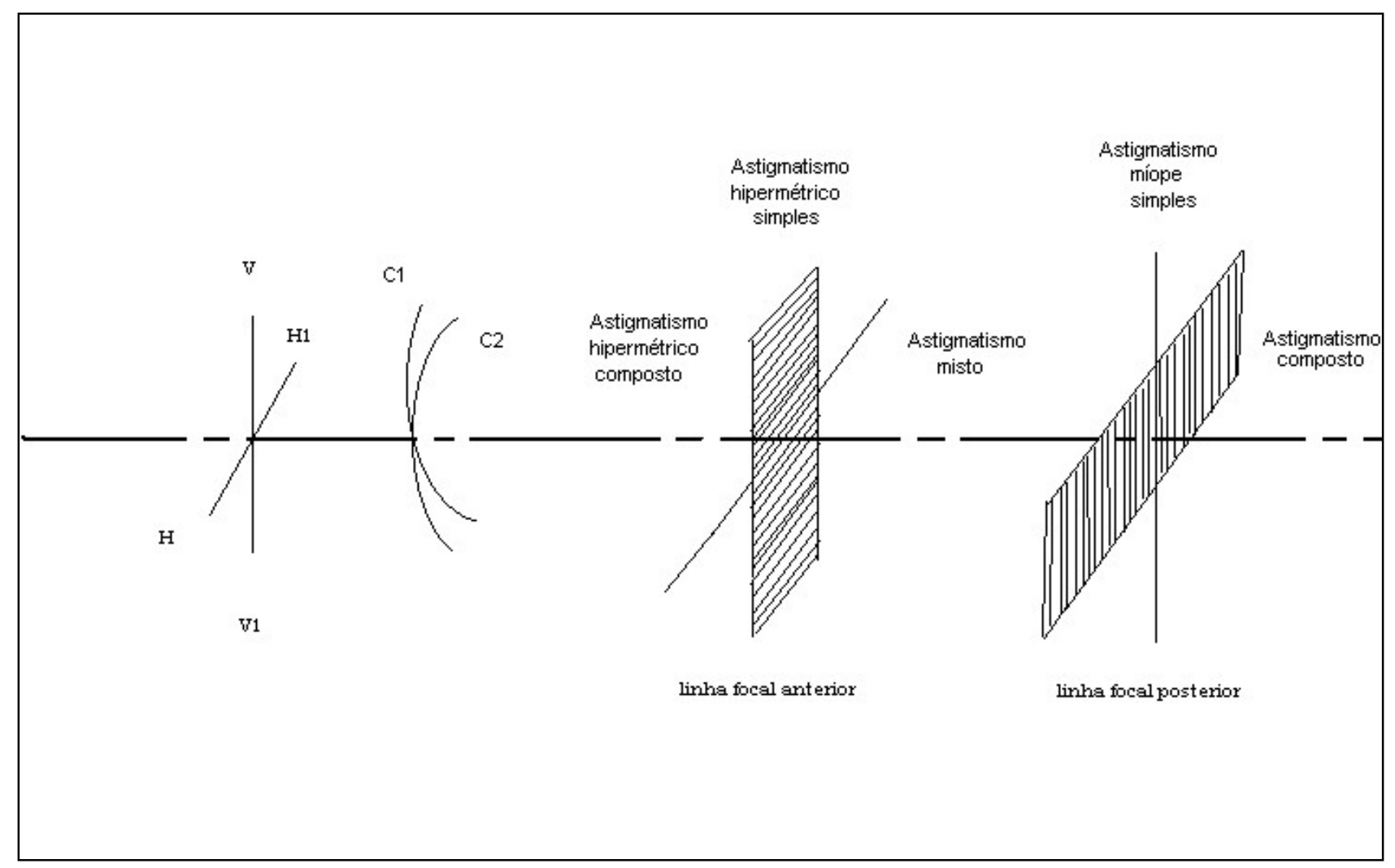

Figura 2.1: Formação da imagem de uma figura em forma de cruz para os vários tipos de astigmatismo regular.

Assim, em todo caso de astigmatismo regular, há uma direção na qual as linhas parecem mais distintas e uma na qual parecem mais confusas. Toma-se vantagem 


\section{O Astigmatismo}

$\overline{\text { disso na detecção do astigmatismo por uma figura em forma de ventilador. Se o eixo }}$ do cilindro for oblíquo, a cabeça é virada para um lado de modo a reduzir a distorção.

\section{3 - CONDIÇÃO ÓTICA}

Uma esfera é uma superfície em que todos os seus meridianos possuem a mesma curvatura (figura 2.2a)

No entanto, nem todas as superfícies são esféricas (astigmáticas, figura 2.2b); aquelas que não são geralmente não formam imagens estigmáticas. Tais superfícies são denominadas tóricas - tipo particular de superfície não esférica (figura 2.2.c).

Um cilindro também pode ser considerado uma superfície tórica, porém com $\mathbf{r}_{2}$ infinitamente longo (figura 2.3a).

Uma das características do cilindro é que o feixe de luz que nele incide, proveniente de um ponto, é refratado de modo a formar uma linha correspondente, ou seja, a cada ponto incidente, há uma linha refratada correspondente. A figura $2.3 \mathrm{~b}$ pode melhor ilustrar este fato.

Podemos observar que a luz, quando incide paralela ao eixo de revolução do cilindro, não sofre desvio. 


\section{O Astigmatismo}

a)

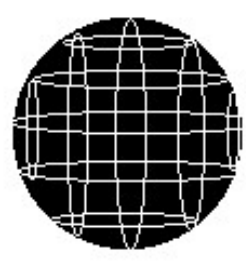

b)

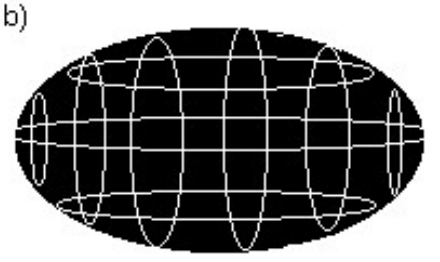

c)

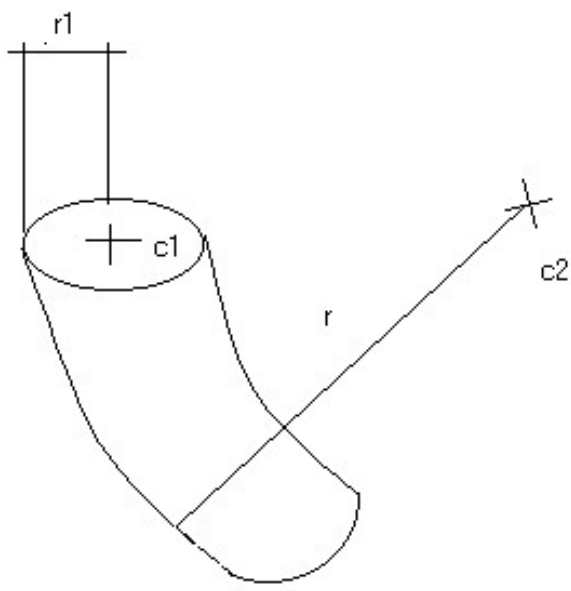

Figura 2.2: Representação de superfícies: (a) esférica; (b) elipsoidal; (c) tórica. 


\section{O Astigmatismo}

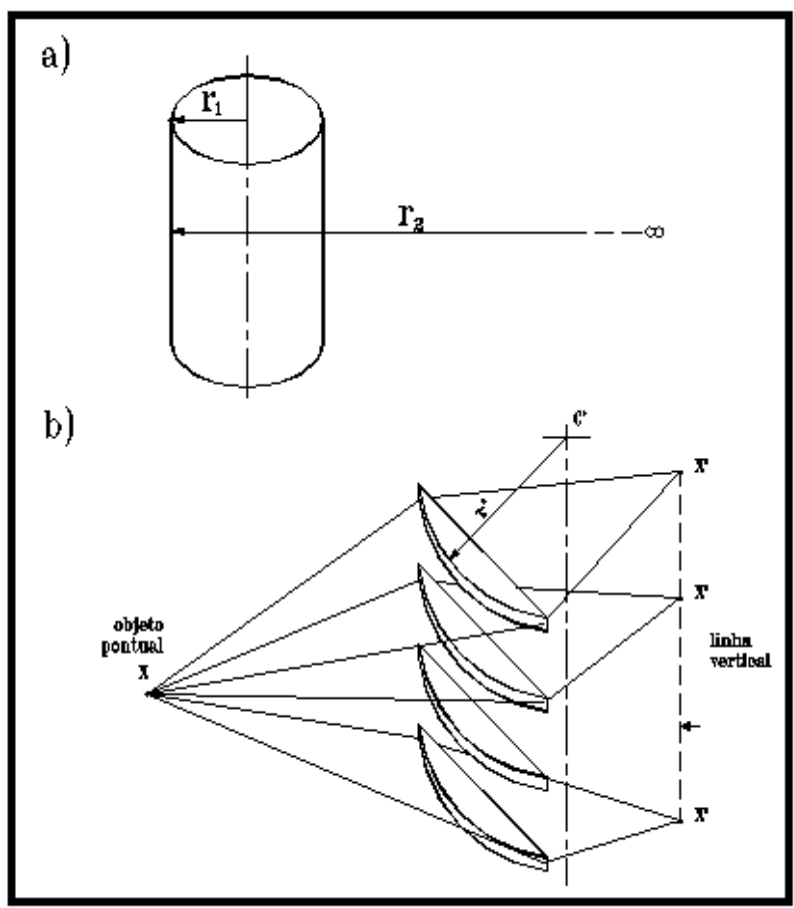

Figura 2.3: (a) Representação de um cilindro; (b) Representação da formação da imagem a partir de um feixe paralelo de luz, proveniente de uma fonte puntual, incidente numa lente cilíndrica.

\section{4 - Círculo de Menor Confusão ${ }^{[2,5]}$}

Observemos a figura 2.4. Um objeto puntual luminoso incide numa lente astigmática formando uma imagem num anteparo. Colocando-se o anteparo paralelo ao plano da lente, na posição $\mathbf{x v}^{\prime}$, observar-se-á uma linha vertical como imagem. Se agora movermo-lo para a posição $\mathbf{x}_{\mathbf{H}}$, formar-se-á uma linha horizontal. 


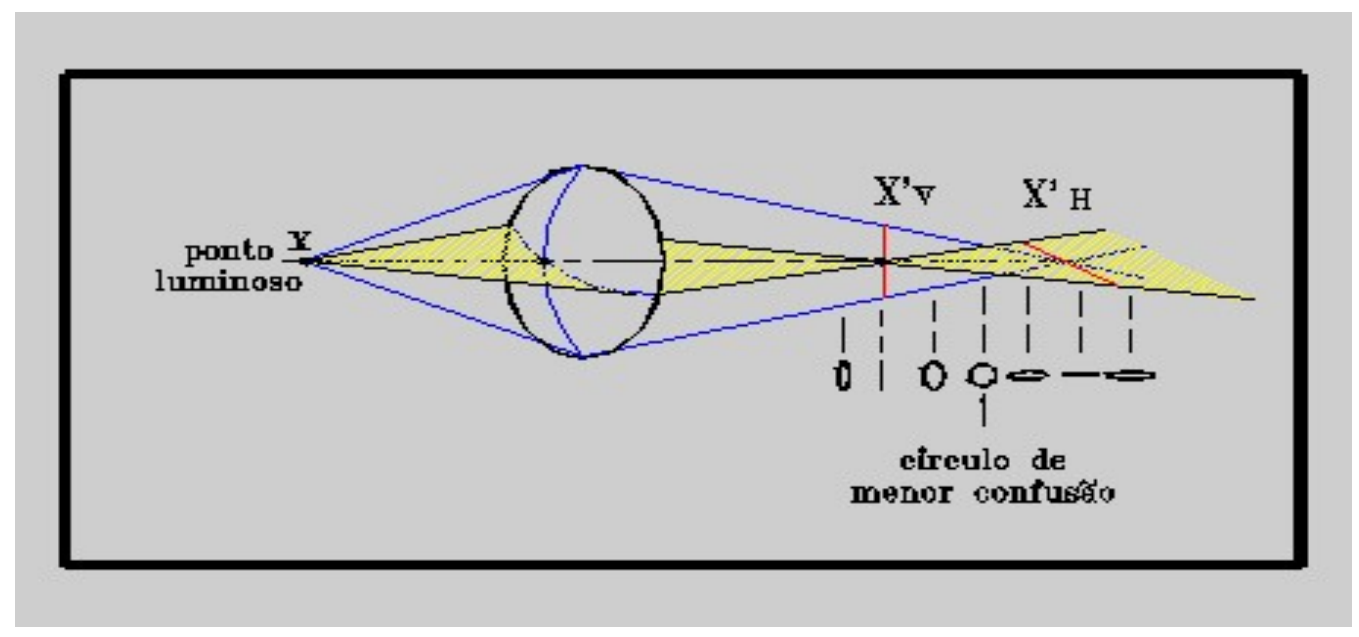

Figura 2.4: Representação do círculo de menor confusão.

Entre essas duas posições, várias imagens formar-se-ão, como ilustrado. Porém, existe um certa posição onde teremos a imagem de um círculo, denominada círculo de menor confusão, e que está exatamente a meio caminho, dioptricamente falando, dos dois focos $\left(\mathbf{x}_{\mathbf{v}^{\prime}}\right.$ e $\left.\mathbf{x}_{\mathbf{H}^{\prime}}\right)$. Clinicamente, esta é a vergência mais importante.

O círculo de menor confusão (ou interfocal) é a imagem borrada (um ponto corresponde a um círculo), porém não distorcida. 


\section{O Astigmatismo}

\section{5 - Algumas Propriedades dos Cilindros}

Há dois tipos de cilindros utilizados na oftalmologia: os cilindros positivo e negativo. Ambos podem ser utilizados para a correção do astigmatismo.

A função ${ }^{[7]}$ que descreve o efeito das lentes cilindricas nos vários meridianos é dada pela função seno ou cosseno, porém de período $\pi$.

\section{6 - O CERATOCONE ${ }^{[8]}$}

Um tipo de astigmatismo acentuado corneano é o denominado "ceratocone". Ceratocone ou cone de córnea, é uma distrofia bilateral incomum no diâmetro da córnea que se torna fina e protuberante, sendo considerado na realidade uma anomalia ou a combinação do desenvolvimento de uma aberração e degeneração da

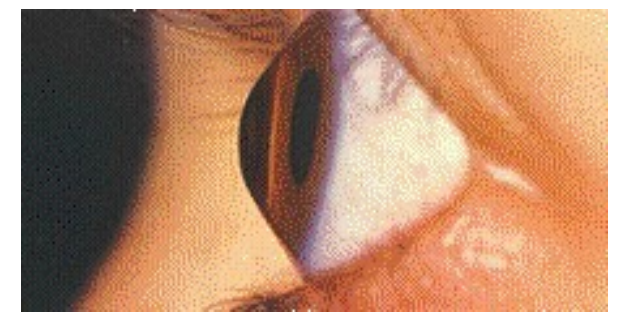

Fig. 2.5 - Olho com ceratocone típico

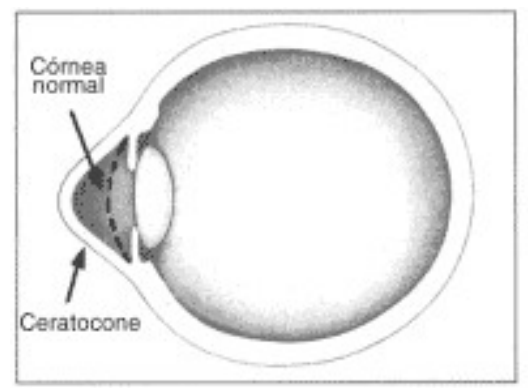

FIG.2.6 - ESQUEMATIZAÇÃO DE UM OLHO COM CERATOCONE 


\section{O Astigmatismo}

A real causa do ceratocone ainda é desconhecida, por outro lado os estudos associam ao mesmo uma degeneração do estroma corneano.

Embaçamento e distorção da visão são os sintomas iniciais do ceratocone, que surgem geralmente na fase pós-adolescência. Ainda na fase inicial a visão é somente levemente afetada, causando ofuscamento, fotofobia e irritações.

O ápice do cone é quase sempre de localização variável, localizado na maioria das vezes abaixo do meridiano horizontal. Algumas investigações tem localizado o ápice abaixo do quadrante temporal em alguns casos.

O ceratocone pode ocasionar na córnea uma sobreelevação de até $2 \mathrm{~mm}$ além do normal (altura de uma córnea normal $\cong 2,5 \mathrm{~mm}$ ). Tal deformidade pode gerar variações de até 1 dioptria na fabricação de lentes de contato.

Casos leves de ceratocone são tratados com sucesso pelo uso de óculos ou de lentes de contato especialmente desenhadas. Quando a visão não é mais satisfatória com nenhum dos meios citados, é recomendado então, um transplante de córnea.

\section{7 - CORREÇÃo ÓtICA DAS AMETROPIAS}

O modo pelo qual ocorre a refração de raios luminosos paralelos em um sistema astigmático já foi descrito. Em vez de um ponto focal isolado, existem duas linhas focais, separadas entre si por um intervalo focal. O comprimento desse intervalo focal é uma medida do grau de astigmatismo, e a correção do erro só é obtida reduzindo-se esses dois focos em um.

Se os dois meridianos principais do sistema astigmático estiverem em ângulos retos entre si, o erro pode ser corrigido pelo emprego de uma lente cilíndrica 


\section{O Astigmatismo}

adequada, que, atuando no plano de um meridiano, então toda a imagem (teoricamente) transformar-se-á num ponto.

Vejamos, então, como proceder para a correção, por exemplo, de uma pessoa astigmática hipermétrope composta, com +3 di e +5 di a $180^{\circ}$ e $90^{\circ}$, respectivamente (figura 2.7a).

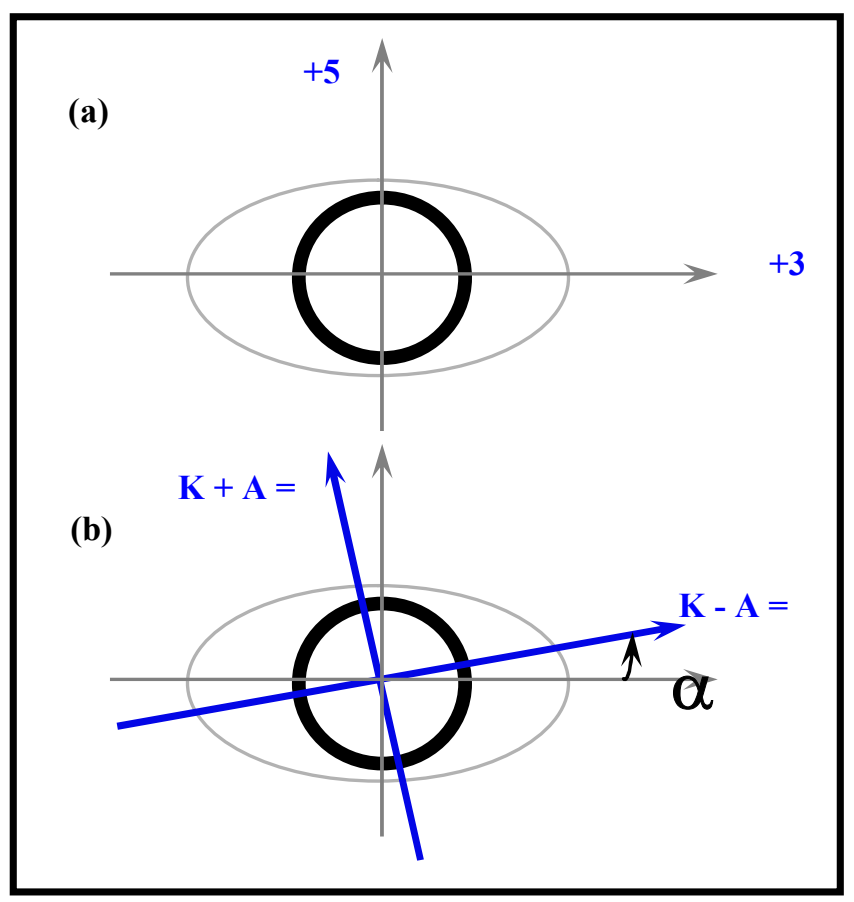

Figura 2.7: Representação da correção ótica de ametropia por lentes esféricas associadas a cilindros positivo e negativo: (a) exemplo particular de ametropia; (b) exemplo genérico de ametropia.

Há dois modos de prescrever a receita para este caso particular, com cilindros positivos ou negativos, este último tipo mais utilizado no Brasil (uma das razões é que é de mais fácil confecção):

$$
+5 \text { esf. } X-2 \text { cil. } 90^{0}
$$

Coloca-se uma lente esférica $+5 \mathrm{di}$. Assim, ambos os meridianos submetem-se a +5 di de poder, de modo que o vertical fica corrigido e o horizontal fica "super" corrigido, remanescendo com -2di. Dessa maneira, devemos corrigir apenas este 


\title{
2. O Astigmatismo
}

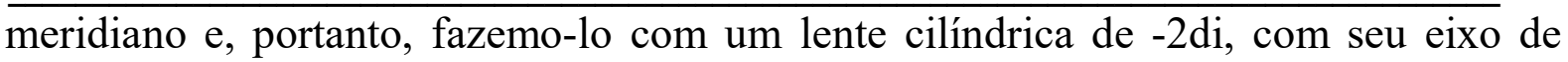
revolução na vertical $\left(90^{\circ}\right)$, a fim de que os raios verticais não sejam refratados.

Então, chegamos à prescrição final de uma lente esférica de poder $+5 \mathrm{di}$, combinada com uma lente cilíndrica de -2 di a $90^{\circ}$.

$$
+3 \text { esf. } X+2 \text { cil. } 180^{\circ}
$$

Procedendo da mesma maneira anterior, só que, agora, utilizando uma lente esférica de $+3 \mathrm{di}$, corrige-se o eixo horizontal, porém não totalmente o vertical, remanescendo +2 di que são corrigidos por um cilindro de poder +2 di e posicionado a $180^{\circ}$ para não interferir nos feixes luminosos horizontalmente incidentes.

Assim, concluímos que, uma vez determinados o maior e o menor poderes de refração de um olho, deve-se proceder do seguinte modo (figura 2.7b): se $y>x$

$$
y \operatorname{esf} X(x-y) \text { cil } \quad\left(\alpha^{0}\right)
$$

ou

$$
\text { x esf }(y-x) \text { cil } \quad\left(\alpha^{0}+90^{\circ}\right)
$$

\section{8 - ASTIGMATISMO - FORMALISMO MATEMÁTICO ${ }^{[0]}$}

\begin{abstract}
Alguns livros da área da oftalmologia ${ }^{[10]}$ afirmam que o astigmatismo ocular pode ser expressado pela função seno elevada à primeira potência, através de deduções matemáticas, porém empiricamente, a expressão correta deve ser a expressão proporcional ao seno elevada à segunda potência.
\end{abstract}




\section{O Astigmatismo}

Aqui neste capítulo é exposto o modo teórico e dedutível da expressão que descreve o astigmatismo ocular.

A figura 2.8 ilustra o gráfico de várias funções senos.

$\mathrm{O}$ astigmatismo ocular é descrito por uma função que possui as amplitudes máxima e mínima a $90^{\circ}$ entre si. Além disto, é variável de 0 à $180^{\circ}$, ou seja, o poder de um determinado meridiano é o mesmo que o do meridiano complementar.

Observemos então, a seqüência da figura 2.8: a função seno de periodicidade $2 \pi$ é graficada segundo o item (a); quando a deslocamos de $\mathrm{K}$ no eixo $y$ temos o item (b); e quando a deslocamos de $\beta$ no eixo $x$, temos o item (c).

Como mencionado acima, o astigmatismo é uma função de periodicidade $\pi$, descrito pelo item (d), e ainda deslocado nos eixos $x$ - item (e) e y - item (f), uma vez que o início das medidas é definido como sendo pelo ponto de mínimo, ou seja, deslocado de $\beta=\pi / 4$ - figuras 2.9.a e 2.10.a - no eixo $x$, e deslocado de $\mathrm{K}$ no eixo $y$, de modo que possa assumir qualquer valor (positivo ou negativo) entre os meridianos de 0 à $\pi / 2$.

Denominando o eixo y como o poder de refração $\mathrm{P}$ e o eixo $\mathrm{x}$ como o ângulo de medida $\theta$, temos:

$$
P=A \operatorname{sen}\left(2 \theta-\frac{\pi}{2}\right)+K
$$




\section{O Astigmatismo}

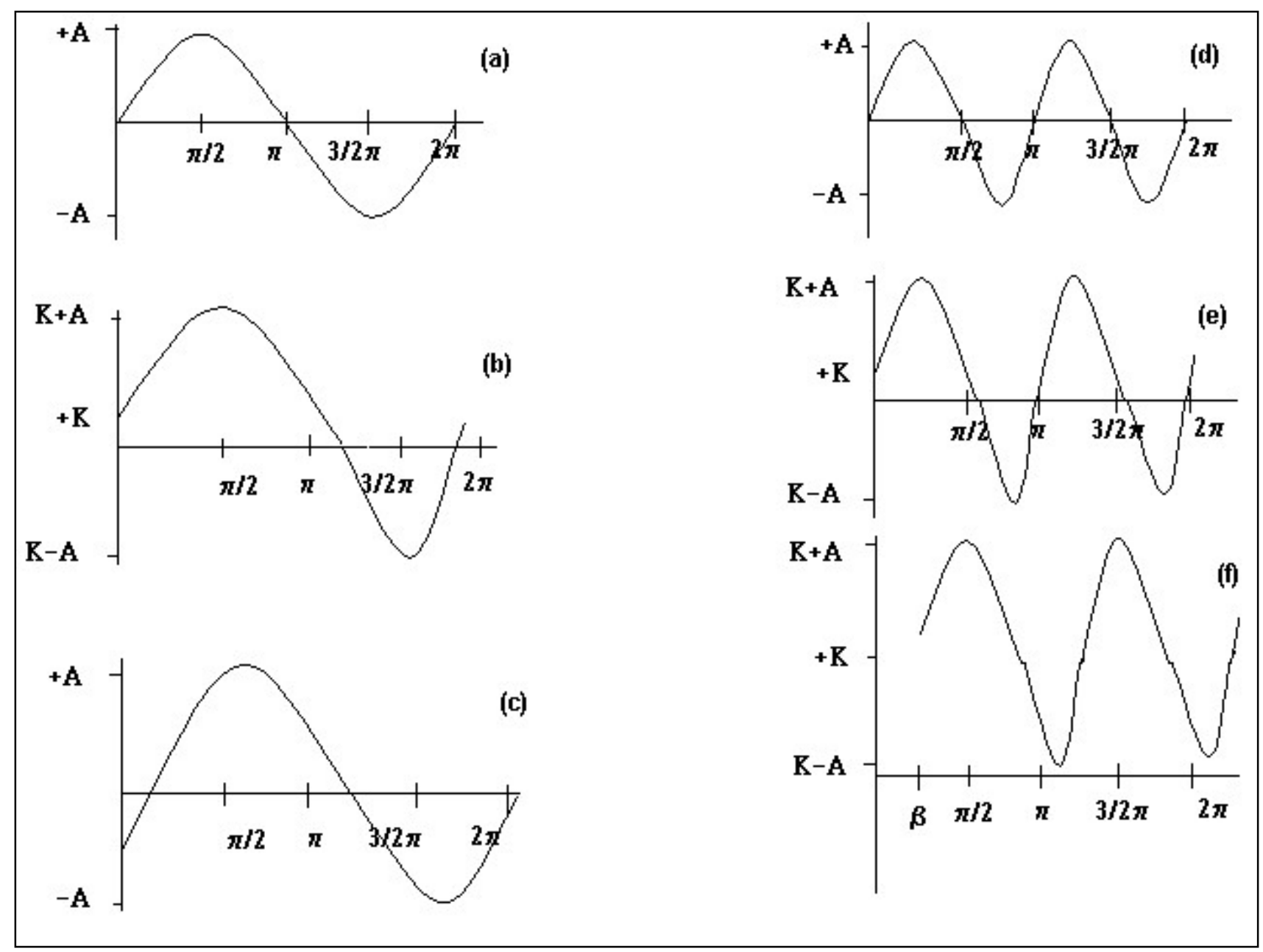

Figura 2.8: Representação das funções (em função do ângulo em radianos): (a) seno, com periodicidade $2 \pi$ e com amplitude $A$; (b) seno, de período $2 \pi$, com amplitude A deslocada de K no eixo y; (c) seno, com periodicidade $2 \pi$ e amplitude $A$, deslocada de $\beta$ no eixo $x$; (d) seno, de período $\pi$, com amplitude $A$; (e)seno, com período $\pi$, deslocada de $\mathrm{K}$ no eixo y; (f) seno, com período $\pi$, deslocada de $\mathrm{K}$ no eixo y e deslocada de $\beta$ no eixo $x$. 


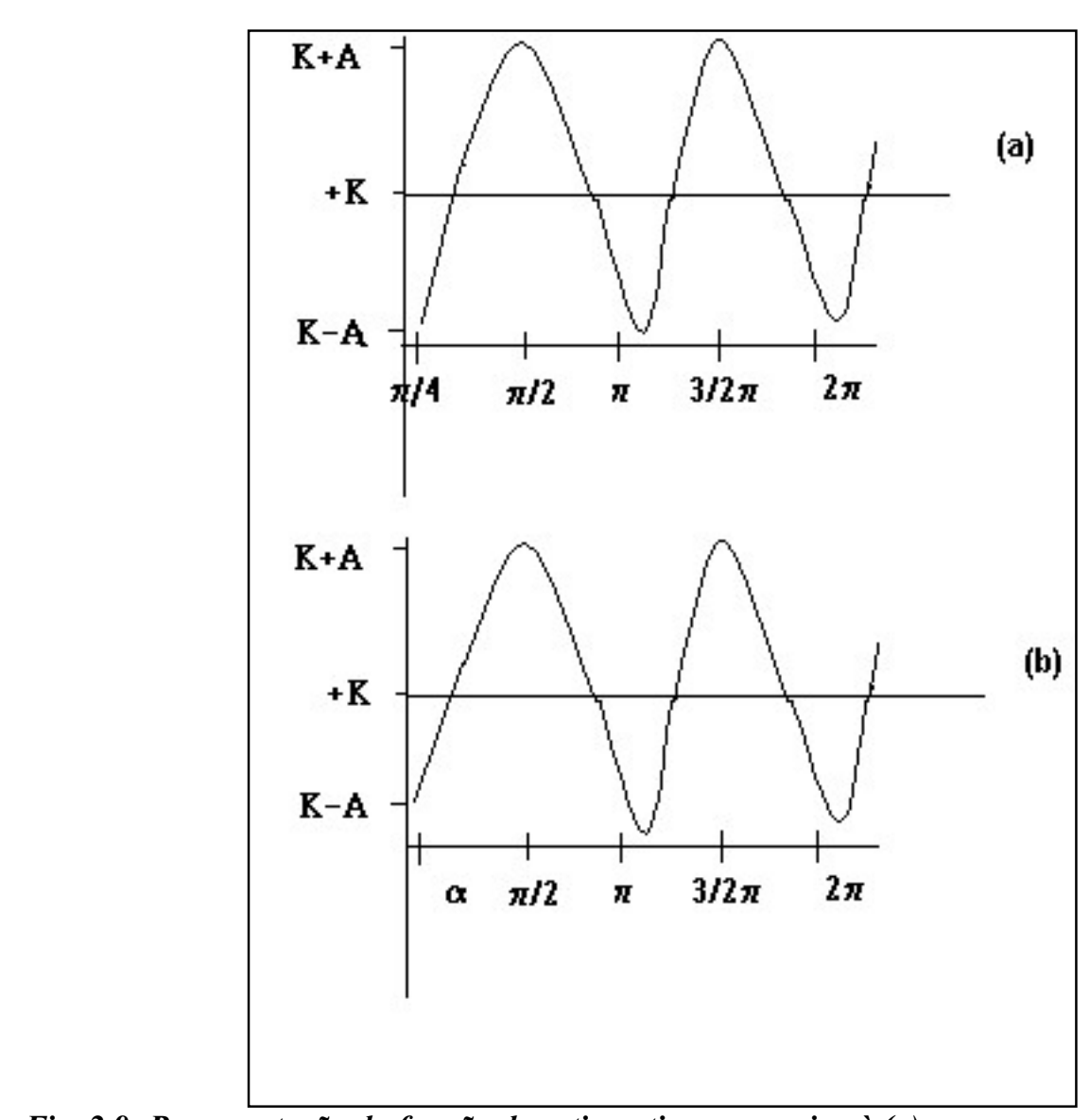

Fig. 2.9: Representação da função do astigmatismo com eixo à (a) zero graus; (b) a graus.

A expressão (2.5) descreve o astigmatismo ocular oblíquo, a favor da regra, onde o menor e o maior poderes estão a $0^{0}$ e a $90^{\circ}$, respectivamente (veja figura 2.10.a).

Para um astigmatismo oblíquo, com menor $(\mathrm{K}-\mathrm{A})$ e maior $(\mathrm{K}+\mathrm{A})$ poderes a $\alpha^{0}$ e a $(\alpha+90)^{0}$ - figura $2.9 \mathrm{~b}$ e figura $2.10 . \mathrm{b}$-, respectivamente, temos a seguinte expressão: 


$$
P=A \operatorname{sen}\left(2 \theta-\frac{\pi}{2}-2 \alpha\right)+K
$$

ou ainda,

$$
P=A \operatorname{sen}\left[2(\theta-\alpha)-\frac{\pi}{2}\right]+K
$$

ou seja,

$$
P=A\left[-1-2 \operatorname{sen}^{2}(\theta-\alpha)\right]+K
$$

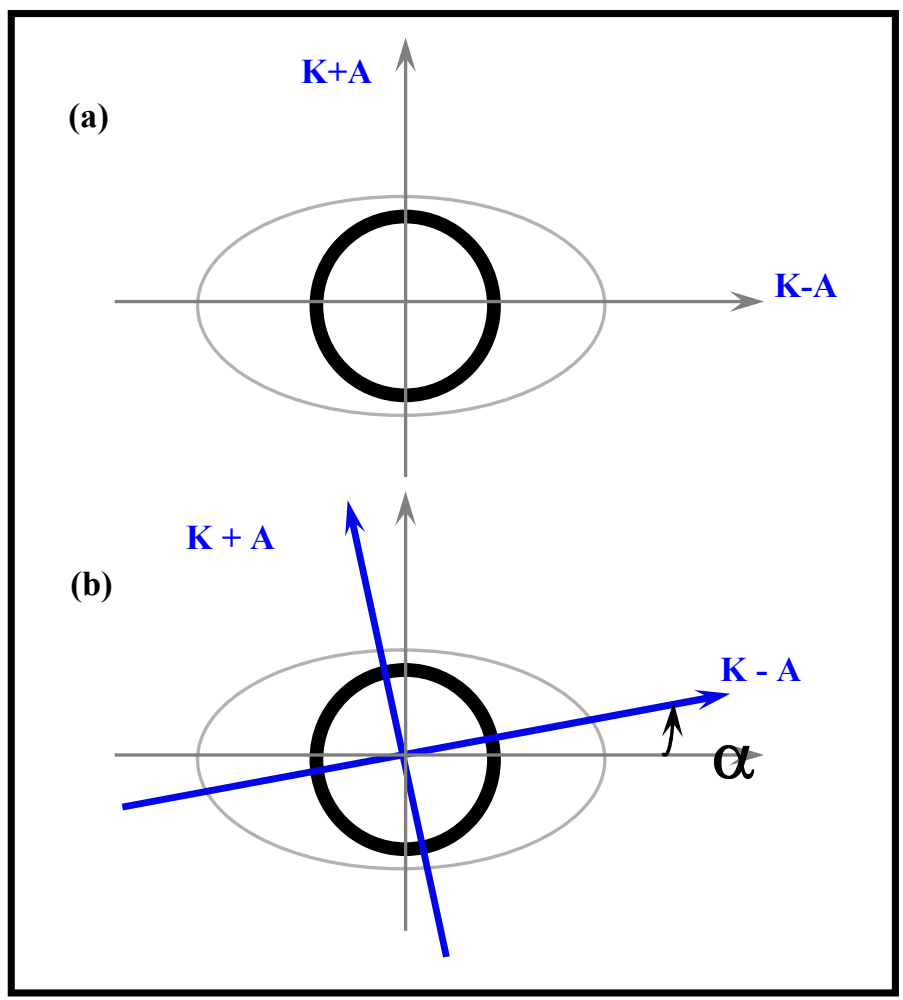

Figura 2.10: Representação esquemática dos astigmatismos: (a) de menor $(K-A)$ e maior poderes $(K+A)$ a $0^{0}$ e a $90^{0}$, respectivamente; (b) de menor (K-A) e maior $(\mathrm{K}+\mathrm{A})$ poderes a $\alpha^{0}$ e a $(\alpha+90)^{0}$, respectivamente. 
Assim,

$$
P=(K+A)-2 A \operatorname{sen}^{2}(\theta-\alpha)
$$

E portanto, chegamos à expressão (2.9), onde $(\mathrm{K}+\mathrm{A})$ é a coordenada esférica (grau de miopia ou hipermetropia), $-2 \mathrm{~A}$ é a coordenada cilíndrica (grau de astigmatismo) e $\alpha$ é o ângulo do eixo do astigmatismo. Observe que a lente cilíndrica corretora estará posicionada a $(\alpha+90)^{0}$.

Se denominarmos $y=K+A$ e $x=K-A$, temos:

$$
\mathrm{P}=y+(x-y) \operatorname{sen}^{2}(\theta-\alpha)
$$

Verificamos assim que o astigmatismo de fato pode ser expresso por uma função seno elevado à segunda potência.

A seguir discutiremos o mais comum instrumento usado para medição do astigmatismo da córnea: os ceratômetros. 
2. O Astigmatismo 


\section{CAPÍTULO 3 - O Ceratômetro}

\section{Convencional}

\subsection{Introdução}

A ceratometria ou também chamada de oftalmometria, representa o estudo das medidas das curvaturas dos meridianos da córnea.

As primeiras medidas da córnea se atribuem a Cristopher Steiner, que comparava o tamanho das imagens refletidas com as obtidas em modelos de raio de curvatura conhecido ${ }^{[6]}$.

O ceratômetro também chamado de oftalmômetro foi um instrumento desenvolvido primeiramente pelo físico Helmholtz (1821-1894) ${ }^{[11]}$, que pela primeira vez o utilizou em 1854 para medição de constantes do olho. O ceratômetro de Helmholtz era na realidade uma modificação de um tipo de heliômetro criado pelo físico Thomas Young ${ }^{[12]}$, consistindo de um telescópio, tendo em frente da objetiva duas miras de vidro com superfícies planas paralelas colocadas lado a lado.

Ao rotacionar as placas, as duas imagens eram separadas e os deslocamentos das imagens podiam ser calculados pelo ângulo obtido entre a mira e o eixo do telescópio. Medidas grosseiras do raio de curvatura da superfície anterior da córnea já haviam sido feitas por outros pesquisadores, que comparavam a imagem formada por reflexão nesta superfície. Tentativas foram realizadas com o objetivo de colocar escalas no plano focal do sistema ótico, mas o movimento das imagens observadas causava grande inexatidão nos resultados até então obtidos. Helmholtz introduz então, o sistema de duplicação das imagens mediante um acessório especial, um prisma ótico. Este princípio de duplicação já era utilizado em instrumentos astronômicos e foi então adaptado ao primeiro oftalmômetro de uso prático ${ }^{[3]}$ (figura 3.2). 


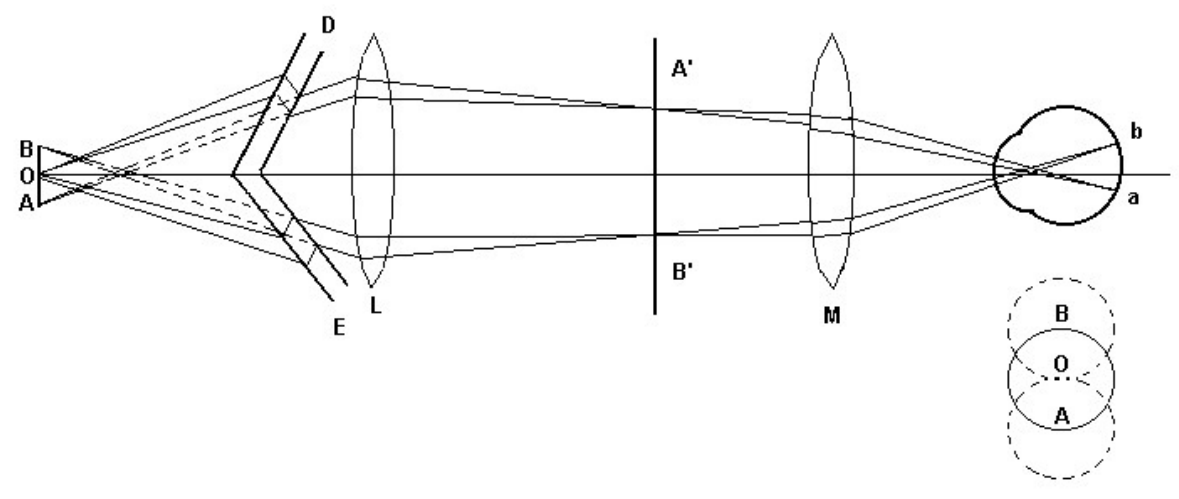

Fig. 3.0 - O Prisma Duplicador de Helmholtz

Louis Émile Javal (1839-1907) ${ }^{[6]}$ e seu aluno Hjalmar Schiotz (1850-1927) ${ }^{[6]}$ ${ }^{[2]}$ refinaram o instrumento para ser utilizado em córneas, medindo-se a diferença entre o meridiano horizontal e vertical, medindo-se o raio de curvatura da córnea.

Utilizando o ceratômetro, Thomas Young demonstrou que mudanças nas lentes e a consequente mudança na acomodação do olho estava relacionada com mudança de curvatura na lente do cristalino. ${ }^{[6]}$

Este ceratômetro era baseado no fato de que, um objeto luminoso colocado diante do olho pode refletir uma porção da luz incidente na superfície anterior da córnea, que atua como um espelho convexo. O tamanho desta imagem depende do tamanho do objeto e da sua distância à córnea, e também do raio de curvatura da córnea, estava então, descoberta a teoria básica que daria impulso à construção de ceratômetros.

Esses instrumentos são todos comumente caracterizados pela dependência da reflexão especular na superfície da córnea, ou mais precisamente, na película 
lacrimal que recobre toda a córnea para determinar o desvio de um círculo perfeito refletido na superfície.

Como vimos anteriormente os ceratômetros foram inicialmente desenvolvidos para proverem uma medida objetiva do astigmatismo da córnea. Com o desenvolvimento das técnicas de refração mais sofisticadas e precisas, a informação dada pelos ceratômetros tornaram-se menos importantes. Mas, com o advento das lentes de contato para correções refrativas do olho, a medida dos raios de curvatura corneanos se tornaram de suma importância para confecção das lentes, daí então o papel de destaque hoje dos ceratômetros.

Os ceratômetros estão divididos em quatro grupos fundamentais: ${ }^{[13]}$

1- ceratômetro de miras fixas e sistema duplicador móvel (tipo Helmholtz)

2- ceratômetro de miras móveis e sistema duplicador fixo (tipo JavalSchiötz)

3- ceratômetros topográficos

4- fotoceratômetros

Cada um destes tipos estão descritos a seguir. 


\subsection{Teoria e funcionamento ${ }^{[11]}$}

\section{Princípio de Funcionamento}

\section{Formação da imagem}

Pela figura 3.3, observa-se que, ao iluminarmos um objeto colocado a uma certa distância da lente de raio $\mathrm{r} 1$, uma imagem virtual deste objeto formar-se-à atrás da lente . Já para um objeto de mesmo tamanho colocado a uma mesma distância de uma lente R2 (r2<r1), observa-se, então que, a imagem virtual formada é menor que a formada pela lente de raio r1. Conclui-se, então, que para um dado tamanho de objeto colocado a uma dada distância de uma lente convexa, o tamanho da imagem formada depende do raio desta lente.
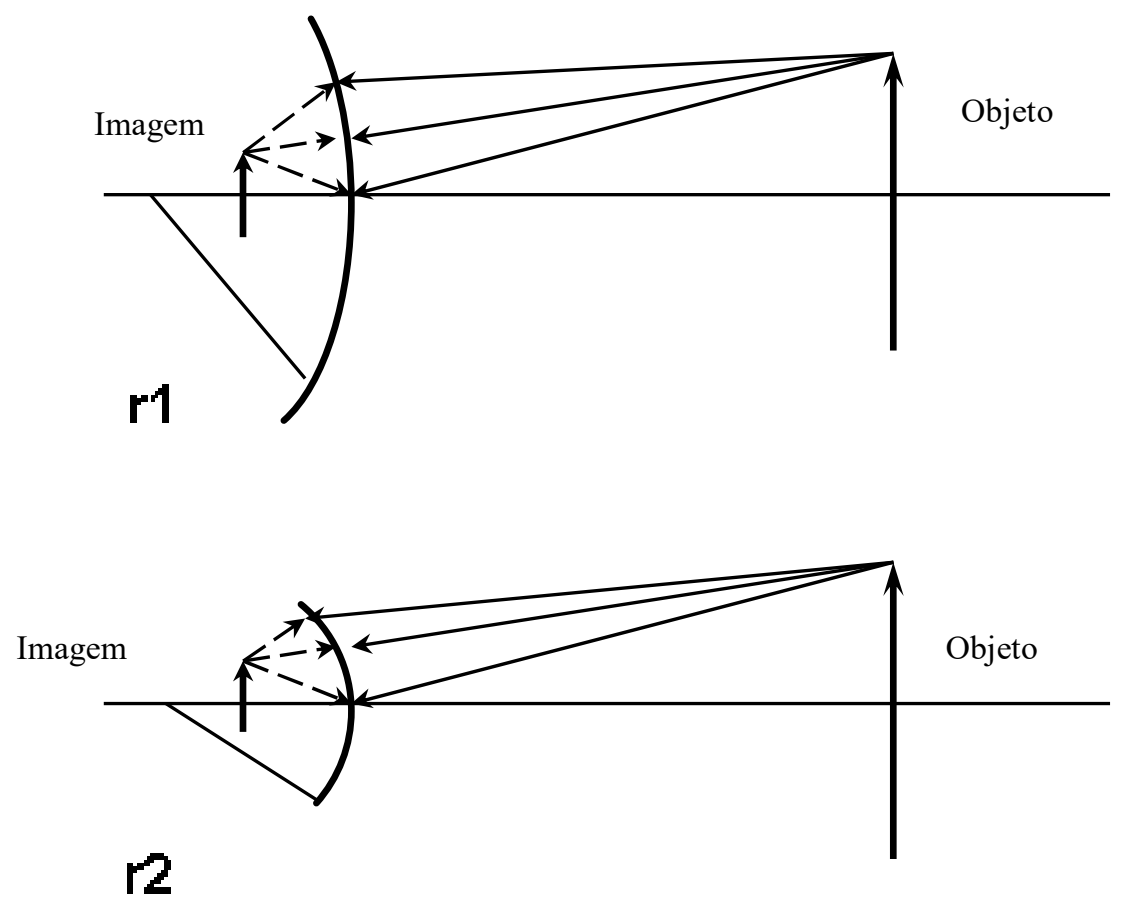

Fig. 3.1 - Princípio do ceratômetro - objeto de dimensão constante.

Na fig. 3.4 utilizam-se as mesmas lentes da fig. $3.3(\mathrm{r} 2<\mathrm{r} 1)$, mas na situação em que as imagens formadas têm o mesmo tamanho e a distância entre os objetos e 
as lentes são as mesmas. Para isso o objeto utilizado para formar a imagem da lente de raio $\mathrm{r} 2$ é maior que o utilizado pela lente de raio r1. Vemos então, que, para manter um tamanho de imagem fixo e para uma distância entre objeto e lente fixa, o tamanho do objeto depende do raio da lente.
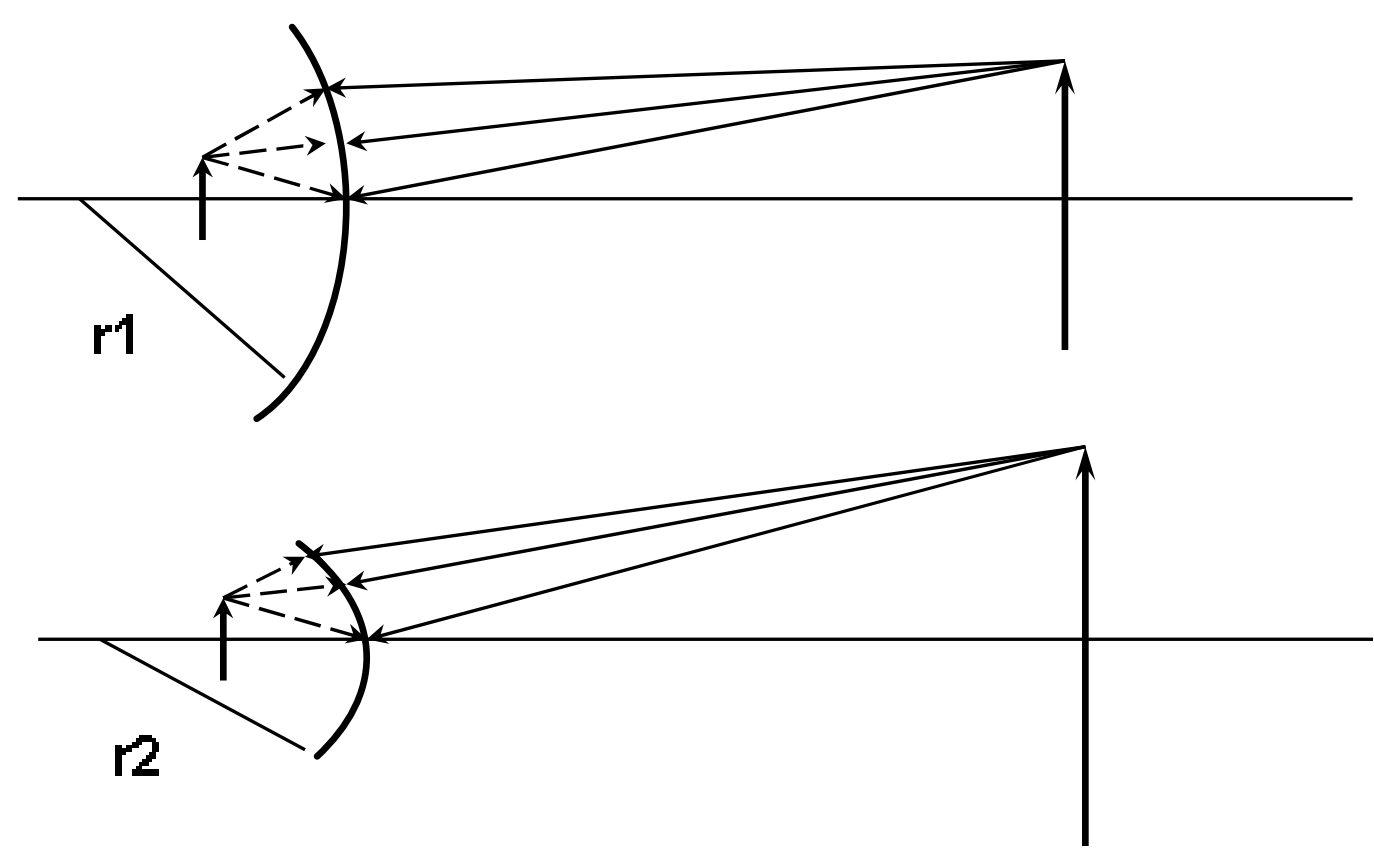

Fig. 3.2- Princípio do ceratômetros - imagem de dimensão constante

Portanto, o ceratômetro faz o papel de lente convexa e o raio de curvatura da córnea é descrito como função do tamanho do objeto constante ou do tamanho da imagem constante.

\section{Princípios Físico - Matemáticos}

Quando um objeto iluminado é colocado na frente do olho, a luz incidente na superfície anterior da córnea é refletida (figura 3.4). Esta superfície que contém uma 
fina película de lágrima, funciona como um pálido espelho convexo e a imagem é formada por reflexão. O tamanho (h') da imagem assim formada depende do tamanho (h) do objeto, da distância da córnea ao objeto e por último do raio de curvatura da córnea. Esta imagem refletida é usada no ceratômetro para obtenção do raio de curvatura da córnea.

$\mathrm{O}$ vértice da córnea é $A$. $\mathrm{O}$ objeto $\mathrm{BQ}=\mathrm{h}$, forma por reflexão, a imagem $\mathrm{B}^{\prime} \mathrm{Q}^{\prime}=\mathrm{h}$ ', três- raios paraxiais típicos são indicados. A imagem pode ser curvada devido à concavidade do centro $\mathrm{C}$, mas pode-se negligenciar as aberrações e considerar a imagem formada como sendo perpendicular ao eixo. A magnificação é tomada pela expressão usual ${ }^{[11]}$ :

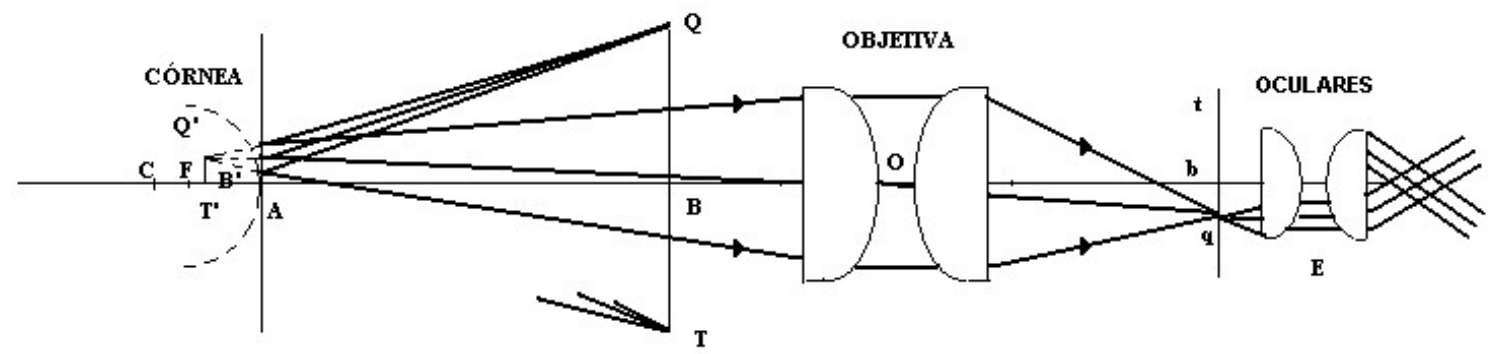

Fig 3.3 - Princípio do Ceratômetro 


$$
m=\frac{h^{\prime}}{h}=-\frac{f}{x}=-\frac{r}{2 x}
$$

Na figura 3.4, AF é a distância focal $f$ e $\mathrm{FB}=\mathrm{x}$, a distância do objeto ao ponto focal. A formação da imagem ao longo do eixo é indicada. Estando o objeto situado em T, em uma igual distância do lado oposto, teremos para o raio de curvatura $r$ :

$$
r=-\frac{2 x}{h} h^{\prime}=-2 m x
$$

Pode-se, então, determinar $\mathrm{r}$, sendo $\mathrm{h}$ constante e medindo-se o tamanho de h'. 


\section{A luz incidente numa superfície esférica}

A penetração da luz na interface entre meios de diferentes índices de refração pode ser descrita através da lei de Snell[ ${ }^{[14]}$. Quando a luz passa por uma superfície curva, como uma esfera a equação é bastante complexa e pode somente ser considerada através de aproximação por uma fórmula simples. A primeira aproximação para a penetração da luz em uma esfera é dada pela fórmula de Littman $^{[11]}$ :

$$
P=\frac{n_{c-} n_{a r}}{r}
$$

,onde

$$
\begin{aligned}
& P \text {; poder de refração } \\
& n_{c} \text {; índice de refração da córnea } \\
& n_{a r} \text {; indice de refração do ar } \\
& r \text {; raio de curvatura d a córnea }
\end{aligned}
$$

O índice de refração é quantitativo, assumindo o valor de 1,3375 para a córnea, e para o ar igual é a 1. Estes números podem, então, ser substituídos na equação acima para mostrar a relação entre o raio em $\mathrm{mm}$ e o poder de refração da superfície anterior da córnea em dioptrias;

$$
P(D)=\frac{337,5}{r}
$$

Esta relação acima é usualmente utilizada em um grande número de ceratômetros, onde seus mostradores fornecem o valor da curvatura da córnea em dioptrias (di) ou em milímetros (mm). Este passo se torna importante para 
realizar esta relação entre o raio de curvatura e o poder em dioptria podendo variar de ceratômetro para ceratômetro.

Parâmetros médios para um olho normal foram obtidos por Gullstrand ${ }^{[3]} \mathrm{e}$ Listing ${ }^{[3]}$ :

Tab. 3.0 - Tabela de Gullstrand e Listing

\begin{tabular}{lll}
\hline Constantes & Gullstrand & Listing \\
\hline Índice de refração da córnea & 1,376 & 1,376 \\
Í́ndice de refração do humor aquoso & 1,336 & 1,336 \\
Índice de refração do cristalino & 1,406 & 1,4545 \\
Índice de refração do humor vítreo & 1,336 & 1,337 \\
Raio de curvatura anterior da córnea & $7,7 \mathrm{~mm}$ & $8,0 \mathrm{~mm}$ \\
Raio de curvatura posterior da córnea & $6,8 \mathrm{~mm}$ & $10 \mathrm{~mm}$ \\
Raio de curvatura anterior do cristalino & $10 \mathrm{~mm}$ & $6,0 \mathrm{~mm}$ \\
Raio de curvatura posterior do cristalino & $5,76 \mathrm{~mm}$ & 66,7 dioptrias \\
\hline Potência total do olho & 58,64 dioptrias & \\
\hline
\end{tabular}

Pode-se observar que, tomando-se os dados de Gullstrand (tabela 3.0) e aplicá-los na fórmula de Littman encontra-se uma convergência de 48,83di para a superfície anterior e uma divergência de 5,882di para a superfície posterior. Ao negligenciar a espessura da córnea (com erro inferior a $0.10 \mathrm{di}$ ) e aplicarmos a teoria das lentes, encontrar-se-á uma refração para a córnea de $42.95 \mathrm{di}=48.83 \mathrm{di}-5.882 \mathrm{di}$.

Observa-se então uma maior refração na superfície anterior da córnea do que na posterior, pois a grande diferença entre o índice de refração do ar e da córnea é maior do que a diferença entre o índice de refração da córnea e o humor aquoso. Tal fato é bastante importante em atos cirúrgicos, já que a uma relativa pequena mudança na superfície anterior da córnea pode criar grandes mudanças na refração ocular. 
Na fabricação de ceratômetros utiliza-se um valor médio para o índice de refração, onde considera-se a divergência da luz também na superfície posterior da córnea, aproximando-se bem aos valores reais. 


\subsection{Ceratômetro de Bausch e Lomb [16], [3]}

Este instrumento possui o mesmo fim que o anterior, no entanto com uma série de modificações que o tornam mais cômodo e exato. É um ceratômetro do tipo miras fixas e duplicador móvel.

Em primeiro lugar, o objeto luminoso que se reflete na córnea é fixo, sendo teoricamente variável a imagem, ainda que na realidade a diferença entre ambos aparatos implica que no primeiro o sistema duplicador é estável e neste é móvel.

Este objeto luminoso é formado por uma circunferência com duas cruzes laterais e dois sinais negativos, superior e inferior respectivamente. Por reflexão na córnea, a imagem deste objeto, colocado na parte anterior do instrumento é transportada ao interior do tubo por quatro orifícios, que tem




por objetivo : o superior e o inferior produzem uma imagem central única, em troca os dois laterais conduzem os prismas, com seus eixos, um na horizontal e outro na vertical, que deslocam as imagens produzidas, um acima e outro lateralmente com respeito ao centro. De tal modo que observador verá três imagens do mesmo objeto (figura 3.9).

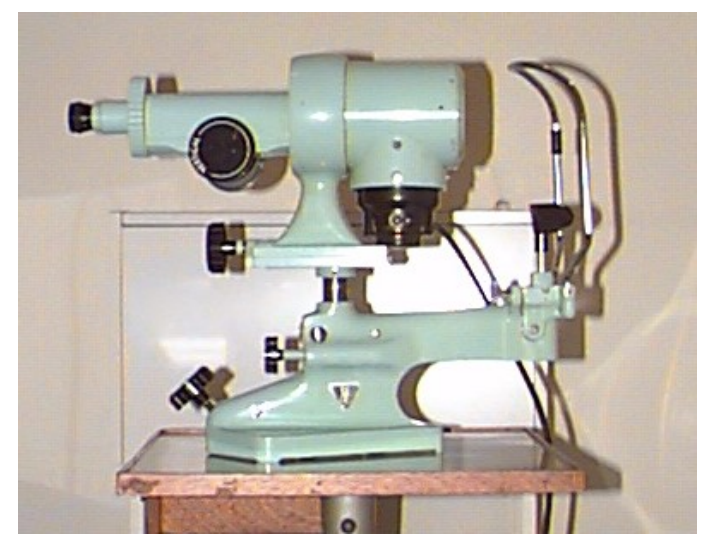

Fig. 3.10 - Vista lateral de um ceratômetro de Bausch e Lomb

Através de tambores conectados aos prismas, é possível movê-los, sendo tal mecanismo chamado e duplicador variável.

Esta disposição permite a leitura simultânea de dois meridianos perpendiculares da córnea, sem necessidade de efetuar ajustes independentes. É suficiente apenas realizar a coincidência dos sinais positivos internos ou de sinais negativos.

Além desta simplificação de operação, a resolução da imagem é independente do observador com o qual não existe o perigo de uma falsa 
apreciação da nitidez, resulte em uma leitura errônea, a acomodação do olho do observador não influi. 


\section{Capítulo 4 - A Lâmpada de Fenda}

Após se ter tido uma boa noção teórica do funcionamento dos ceratômetros convencionais e de tê-los testados no ambulatório do Hospital das Clínicas de Ribeirão Preto, optamos por construir um ceratômetro de miras fixas e tamanho de imagem variável, tal qual o último descrito no capítulo anterior. Ainda com o objetivo de torná-lo automatizado e de mais baixo custo, foi utilizada uma Lâmpada de Fenda ${ }^{[17]}$ (biomicroscópio ocular) como base. A seguir, uma explicação detalhada sobre a Lâmpada de Fenda e seu funcionamento será feita, previamente a apresentação do sistema desenvolvido neste projeto.

\subsection{Introdução}

Um dos instrumentos mais utilizados na prática oftalmológica é a Lâmpada de Fenda. Este instrumento projeta no olho do paciente um feixe de luz no formato de uma fenda. Esta fenda de luz intensa pode ser posicionada em várias regiões do olho, assim como em várias profundidades do mesmo, possibilitando um exame interno e externo do olho.

Mery em 1704, ao mergulhar um gato em uma cuba d'água e observar os vasos retinianos daquele animal, foi o primeiro a verificar que os meios oculares eram transparentes e como tal poderiam ser examinados. Foi realizado então um exame do fundo do olho com a neutralização do índice de refração da córnea ( $n_{\text {água }} \cong n_{\text {olho }}$ ). A partir daí então iniciou-se o estudo da óptica ocular e também a construção de equipamentos que deram origem às Lâmpadas de Fenda atuais. 
No entanto, a primeira Lâmpada de Fenda só foi construída em 1911 por Gullstrand ${ }^{|6|}$, que apresentou seu invento do primeiro modelo de Lâmpada de Fenda em um Congresso em Heidelberg, na Alemanha. O modelo de Gullstrand permitiu de maneira mais satisfatória a iluminação da parte anterior do olho para exames.

De uma forma geral, as LF são constituídas de dois sistemas ópticos principais: o sistema de iluminação e o biomicroscópio. O primeiro é dedicado a produzir uma fenda de luz intensa homogênea e definida, enquanto o segundo providencia o aumento da imagem do olho iluminado. Aqui, adentrar-se-à em cada um dos principais componentes deste equipamento, concentrando-se na parte óptica de funcionamento do biomicroscópio.

\subsection{O Biomicroscópio}

Um biomicroscópio é simplesmente um sistema óptico o qual permite-nos observar uma imagem de um objeto próximo aumentada, no caso, o olho humano.

Quando um dispositivo óptico possui um número de lentes igual ou superior a dois, então este dispositivo é chamado de microscópio composto. O dispositivo consiste de uma lente objetiva a qual gera uma imagem real e invertida, e de uma lente ocular, que constrói uma imagem a partir de uma dada distância e também promove um aumento adicional (figura 4.0). 


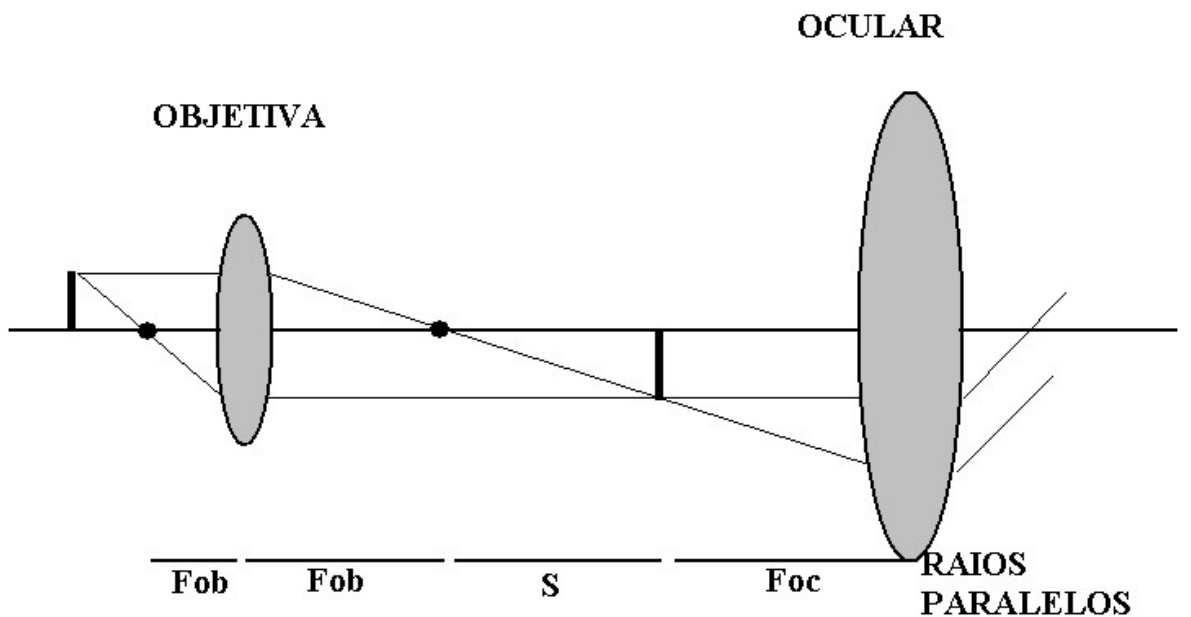

Fig. 4.0 - Desenho esquemático de um microscópio composto

Quando um objeto é colocado próximo da distância focal da objetiva a separação das lentes é então ajustada de forma que a imagem invertida, real e aumentada do objeto produzida pela objetiva seja então posicionada na distância focal da ocular. Sendo a distância focal da objetiva Fob e a distância da ocular Foc, o aumento produzido pela objetiva será :

$$
m=-\frac{S}{F o b}
$$

onde $\mathrm{S}$ corresponde à da lente até à imagem invertida, sendo que para isto tomamos $\mathrm{S}>>$ Fob.

Como observamos a imagem final geralmente é real porém invertida, o que pode tornar extremamente difícil as observações a serem feitas. Entretanto, é possível rotacionar a imagem através de prismas, que são chamados prismas de Porro, cujo princípio básico é a reversão da imagem através de reflexões internas e que veremos a seguir. 


\subsection{Princípio de Funcionamento da Lâmpada de Fenda}

A construção da Lâmpada de Fenda é baseada no microscópio composto, isto é, com número de lentes igual ou superior a dois. Assim, em sua forma mais simples, esse dispositivo também consiste de uma lente objetiva a qual gera uma imagem real e invertida, e de uma lente ocular, que constrói uma imagem a partir da primeira à uma distância visual confortável (geralmente no infinito), e também providencia um aumento adicional, como mostra a Figura 4.1.

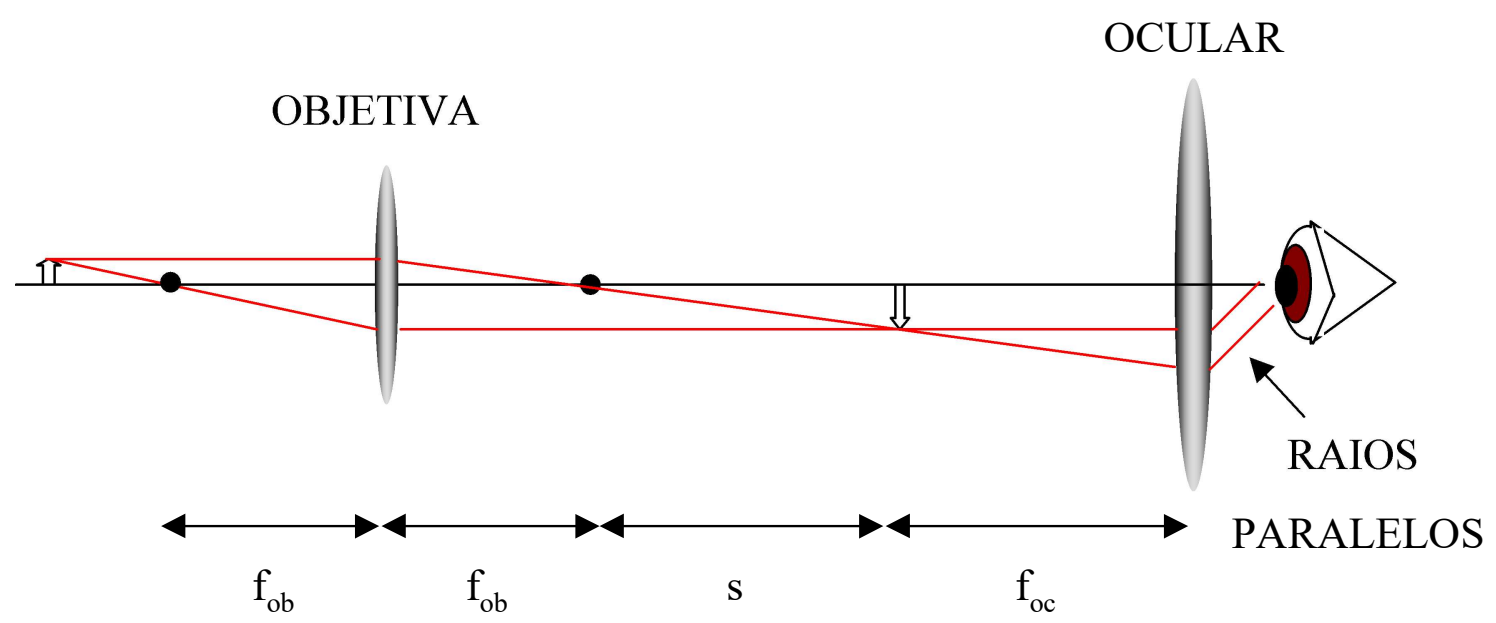

Figura 4.1: Esquema de um microscópio composto.

Se um objeto a ser visualizado é colocado perto do distância focal da objetiva, a separação das lentes é então ajustada de forma que a imagem invertida, real e aumentada do objeto produzida pela objetiva é posicionada na distância focal da ocular. Assim, o aumento total visto pelo observador é o produto do aumento linear pelo aumento angular produzido pela ocular. 
Na maioria dos sistemas a imagem final é real e invertida, o que pode ser uma desvantagem, principalmente em sistemas clínicos. Entretanto, é possível rotacionar a imagem através de reflexões internas em um prisma. $\mathrm{O}$ mais utilizado nestes sistemas é o prisma de Porro. ${ }^{[18]}$ A Figura 4.2 esquematiza esse sistema.

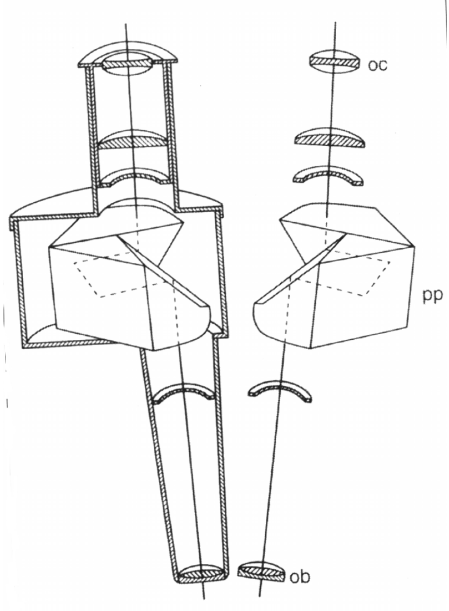

(a)

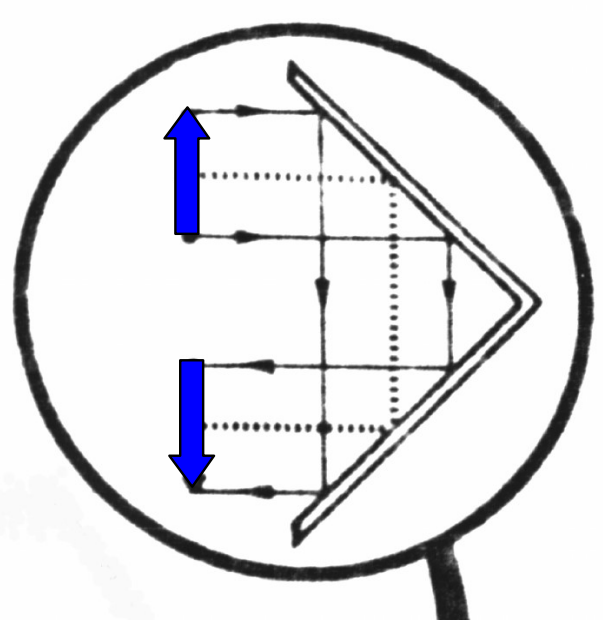

(b)

Figura 4.2: (a) Sistema de um microscópio composto real utilizando o prisma de Porro (pp) ${ }^{R}$; (b) Esquema do funcionamento do prisma de Porro ${ }^{R}$.

\subsection{Mudança de Aumento Galileana ${ }^{[17]}$}

Este sistema utiliza o princípio óptico utilizado em telescópios refrativos (chamados também de Galileanos), para alterar o aumento da imagem. Um telescópio Galileano possui essencialmente lentes positivas e lentes negativas, com o segundo ponto focal da lente positiva coincidindo com o primeiro ponto focal da lente negativa, como mostra a Figura 4.3. 


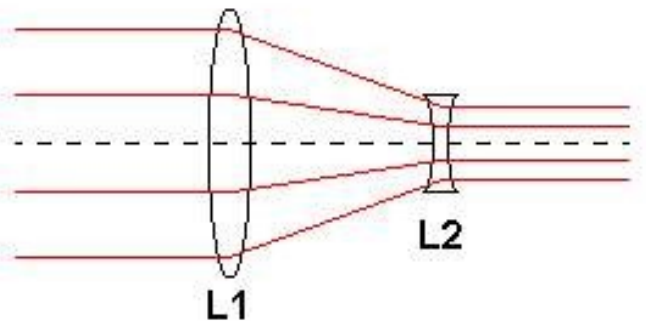

Figura 4.3: Desenho esquemático de um telescópio de Galileo.

O princípio básico do telescópio de Galileo é utilizar a luz paralela de um objeto distante, alterar seu aumento e formar a imagem do objeto no infinito. Os raios paralelos, provindos de um objeto distante, ou de um feixe colimado, atingem a lente objetiva, fazendo um ângulo $\theta$ com o eixo do sistema óptico (lentes objetiva e ocular), formando uma imagem real e invertida sobre o ponto focal comum entre as lentes. Esta imagem então age como um objeto para a ocular e o observador vê uma imagem ainda invertida e virtual do objeto.

Um telescópio Galileano com uma distância focal para a lente objetiva com distância focal de $10 \mathrm{~cm}$ e $-5 \mathrm{~cm}$ para a distância focal da ocular possui um aumento de 2.0X. Porém, esta configuração pode ser rotacionada de $180^{\circ}$, e então estaremos trocando a lente objetiva pela ocular e vice versa. Assim, o aumento agora torna-se $0.5 \mathrm{X}$

As Lâmpadas de Fenda modernas possuem um tambor giratório onde estão posicionados dois telescópios de Galileu, com valores diferentes para as lente, propiciando estes dois telescópios 4 tipos de aumento diferentes. Existe ainda um terceiro orifício no tambor, onde não existem lentes, produzindo assim ampliação zero (neste componente), o que resulta na possibilidade de 5 aumentos diferentes na Lâmpada de Fenda somente girando o tambor. Estes aumentos estão situados entre 5 e 50 aumentos típicos para telescópio de Galileo utilizados são de 2/3 e 2/5 produzindo 
um aumento total na Lâmpada de Fenda de 06, 10, 25 e 40 vezes, sendo que 16 vezes é o aumento sem o telescópio.

\subsection{Resolução}

A linha fundamental de qualquer sistema óptico não é a magnificação, mas a resolução (qualidade da imagem formada pelo sistema óptico). Os dois fatores mais importantes são o obstáculo de abertura e o de campo, cuja função é limitar a passagem da luz através do sistema óptico. No caso do microscópio simples, por exemplo, o obstáculo de campo é a borda da própria lente, e a abertura é o diâmetro livre da lente.

O obstáculo de abertura determina o diâmetro do cone de luz que pode passar através do sistema (um exemplo é o diafragma da íris que limita a luz na câmara). $\mathrm{O}$ obstáculo de abertura não altera o tamanho do campo nem da imagem, apenas o brilho da imagem.

O obstáculo de campo é quem realmente limita o tamanho do campo. Vamos usar como exemplo um garoto assistindo um jogo por um buraco em um muro. $\mathrm{O}$ obstáculo de abertura é a íris do olho do garoto, enquanto que o obstáculo de campo é o orifício no muro.

A resolução de um sistema é função de dois fatores: aberrações das lentes e efeito de difração. Ambos são dependentes do tamanho do obstáculo de abertura. 
No caso das aberrações das lentes, a porção mais periférica da lente contribui com aberrações maiores, como aberrações esféricas, e portanto, os obstáculos de abertura maiores aumentam também estas aberrações. A princípio estas aberrações podem ser compensadas por lentes adicionais com aberrações opostas, mas na prática isto não acontece, e se a abertura for aumentada demasiadamente, as aberrações atingem níveis inaceitáveis. Visto que as aberrações mais intensas desaparecem quando o obstáculo de abertura tende a zero, são utilizadas aberturas muito pequenas e compensa-se a diminuição do brilho da imagem usando uma fonte luminosa mais intensa.

Contudo, quando a abertura (opaca) possui dimensões comparáveis ao comprimento da luz que a atravessa, a luz tende a se espalhar pela região até então de sombras. Este efeito é conhecido como difração de Fraunhofer ${ }^{[18]}$ e depende do comprimento de onda da luz e da dimensão da abertura. Quando uma abertura circular torna-se cada vez menor, a borda torna-se cada vez mais proeminente e a difração, uma série de anéis concêntricos, torna-se mais evidente. O tamanho destes anéis limitam a resolução de um sistema de lentes; grandes diâmetros de orifícios originam discos progressivamente menores e potencialmente aumentam o poder de resolução, se desprezarmos as aberrações. Do ponto de vista do efeito de difração, o ideal seria um diâmetro infinito.

Uma distância muito pequena entre a lente e o objeto tem o mesmo resultado. Outra maneira de manipular a resolução é mudar o índice de refração do meio onde se forma a imagem ou do meio onde o objeto está localizado. Isto é feito em alguns microscópios usando óleo de imersão na objetiva. Outra variável que pode ser alterada para aumentar a resolução do sistema é o comprimento de onda da luz para a região do azul, porém há limites definidos dos comprimentos os quais podem ser usados no olho humano. 
Assim, por um lado procura-se reduzir a dimensão do obstáculo de abertura, a fim de reduzir aberrações e por outro, procura-se aumentá-lo, pois assim reduzem-se os efeitos indesejáveis da difração. Deve-se então buscar um ponto de equilíbrio entre esses efeitos a fim de minimizá-los.

Para a Lâmpada de Fenda ${ }^{[17]}$, foi mostrado que a melhor qualidade de imagem ocorre com pupila entre 2 a $2,5 \mathrm{~mm}$, mais que $3 \mathrm{~mm}$ grandes aberrações não permitem boa qualidade de imagem, uma vez que a pupila atua também como uma fenda para o sistema óptico.

\subsection{Brilho da Imagem}

O brilho da imagem é função de muitos fatores, como o tamanho da pupila da Lâmpada de Fenda, a transmissão, aumento, iluminação da lâmpada e capacidade do objeto refletir. A característica de uma lente de transmitir luz irradiada é função de duas propriedades: a reflexão que ocorre na superfície entre dois meios ópticos, e a perda de transmissão devido à absorção de luz pelo próprio elemento óptico. A absorção pela lente é facilmente manipulado através da qualidade e tipo de material do sistema óptico, e é em geral reduzida para a maioria dos aparelhos ópticos, como a própria Lâmpada de Fenda. Portanto, a transmissão total dos elementos ópticos da Lâmpada de Fenda é essencialmente função da perda de reflexão de cada superfície.

Certa quantidade de luz é refletida pela superfície dos componentes ópticos devido a diferença entre os índices de refração entre o ar e o material que o sistema é constituído. A luz incidente na superfície do sistema óptico é refletida, viaja pelo meio, é parcialmente refletida novamente pela superfície anterior e este efeito continua em 
outras superfícies. Estas reflexões podem ser responsáveis pelas imagens fantasmas ou enfraquecimento desta, diminuindo o contraste da imagem final.

\subsection{Profundidade de Campo}

Outra característica que influencia na utilidade da Lâmpada de Fenda é a profundidade do campo, que depende tanto da profundidade do foco da lâmpada quanto da habilidade de acomodação visual do operador. A profundidade do foco da Lâmpada de Fenda é uma característica própria do aparelho. Já a habilidade para acomodação visual relaciona-se com a idade do observador.

\subsection{Sistema de Zoom}

Para compreendermos o princípio do sistema de zoom, vamos considerar uma lente simples de $+3,0$ di com um objeto a $50 \mathrm{~cm}$ a sua frente. A vergência dos raios originados do objeto até a lente será de $-2,0$ di, a vergência dos raios que deixam a lente será de $+1,0$ di e a imagem formar-se-á a $1 \mathrm{~m}$ atrás da lente. A distância total do sistema do objeto à imagem será $1,5 \mathrm{~m}$. Se o objeto estiver a $1 \mathrm{~m}$ da lente, a imagem formar-se-á $50 \mathrm{~cm}$ atrás da lente e novamente a distância total do sistema será $1,5 \mathrm{~m}$. Entretanto a magnificação, que é a relação entre as distâncias, será de 0,5 no primeiro caso e 2,0 no segundo. Portanto, é possível alterar a magnificação do sistema sem alterar sua distância total.

O sistema de zoom possui vantagens sobre o foco fixo, pois permite um ajuste contínuo do aumento. Porém, são mais caras e mais sensíveis à posição do objeto que outros sistemas.

\subsection{Sistema de Iluminação}


O sistema de iluminação utilizado pelas Lâmpadas de Fenda, é o de Kohler$\operatorname{Vog} t^{171}$. Esse sistema, mostrado na Figura 4.4, é composto por um filamento luminoso (fl), lentes coletoras (lc), fenda diafragmática (fd) e uma lente de iluminação (li).

O bulbo (filamento luminoso) é colocado próximo ao sistema de lentes coletoras (lc), de modo que a imagem do filamento luminoso forma-se na superfície posterior da lente de iluminação (li). A fenda diafragmática (fd) é usada aqui, essencialmente como um regulador do tamanho do feixe. A abertura homogeneamente iluminada do sistema de lentes coletoras (lc), é usada como fonte e forma um campo de luz uniforme.

Para que o sistema de Kohler-Vogt produza uma imagem homogênea do filamento, é indispensável que ele esteja bem próximo à lente condensadora (lc). Mesmo um pequeno hiato entre o filamento (fl) e o sistema de lentes condensadoras (lc) é suficiente para causar uma heterogeneidade do foco e isso pode ser fonte de problemas nas lâmpadas de fenda de qualidade inferior, se se desejar realizar exames ou medidas mais demorados e detalhados.

Quando o princípio de Kohler-Vogt é usado, somente uma pequena parte da lente de iluminação (li) é ocupada pela imagem do filamento (ifl). Isso pode dispensar o uso de uma lente asférica como lente de iluminação (li), pois a parte central de uma lente está isenta de aberrações. Por outro lado, é utilizada uma lente acromática, isto é, com diferentes raios de curvaturas nas duas superfícies da lente iluminadora (li), sendo a superfície do raio menor voltada para a fenda.

A distância focal das lentes de iluminação (li) das várias lâmpadas de fenda disponíveis no mercado varia entre $70-100 \mathrm{~mm}$. Se encurtamos essa distância focal, aumentaremos a luminosidade da imagem, mas, simultaneamente, reduzimos a profundidade de foco. Em nosso caso, (li) $=70 \mathrm{~mm}$. 


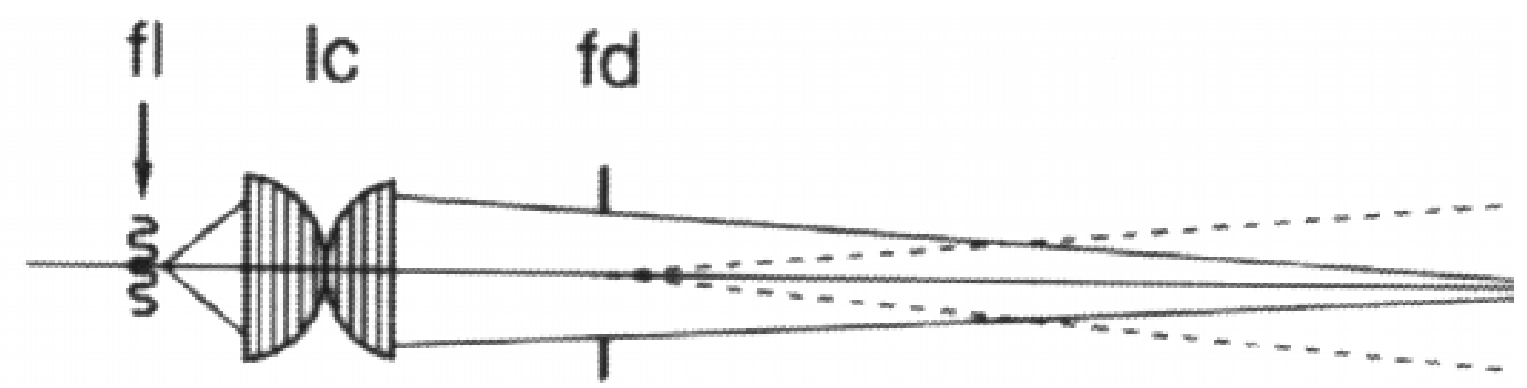

Figura 4.4: Esquema do sistema de iluminação de Vogt, onde a iluminação produzida é mais homogênea.

\subsection{Esquema Geral de uma Lâmpada de Fenda com Telescópio de}

\section{Galileo}

A Figura 4.5 mostra esquematicamente o sistema óptico de uma Lâmpada de Fenda.

Podemos separar as lâmpadas de fenda em dois tipos: as fabricadas pela Haag Streit, e as fabricadas pela Carl Zeiss. A primeira diferença entre estas lâmpadas está na forma de iluminação. As lâmpadas da Carl Zeiss possuem o sistema de iluminação por baixo, enquanto que as lâmpadas da Haag Streit, o sistema é por cima, figuras $4.6 \mathrm{a}$ e $4.6 \mathrm{~b}$, respectivamente. 


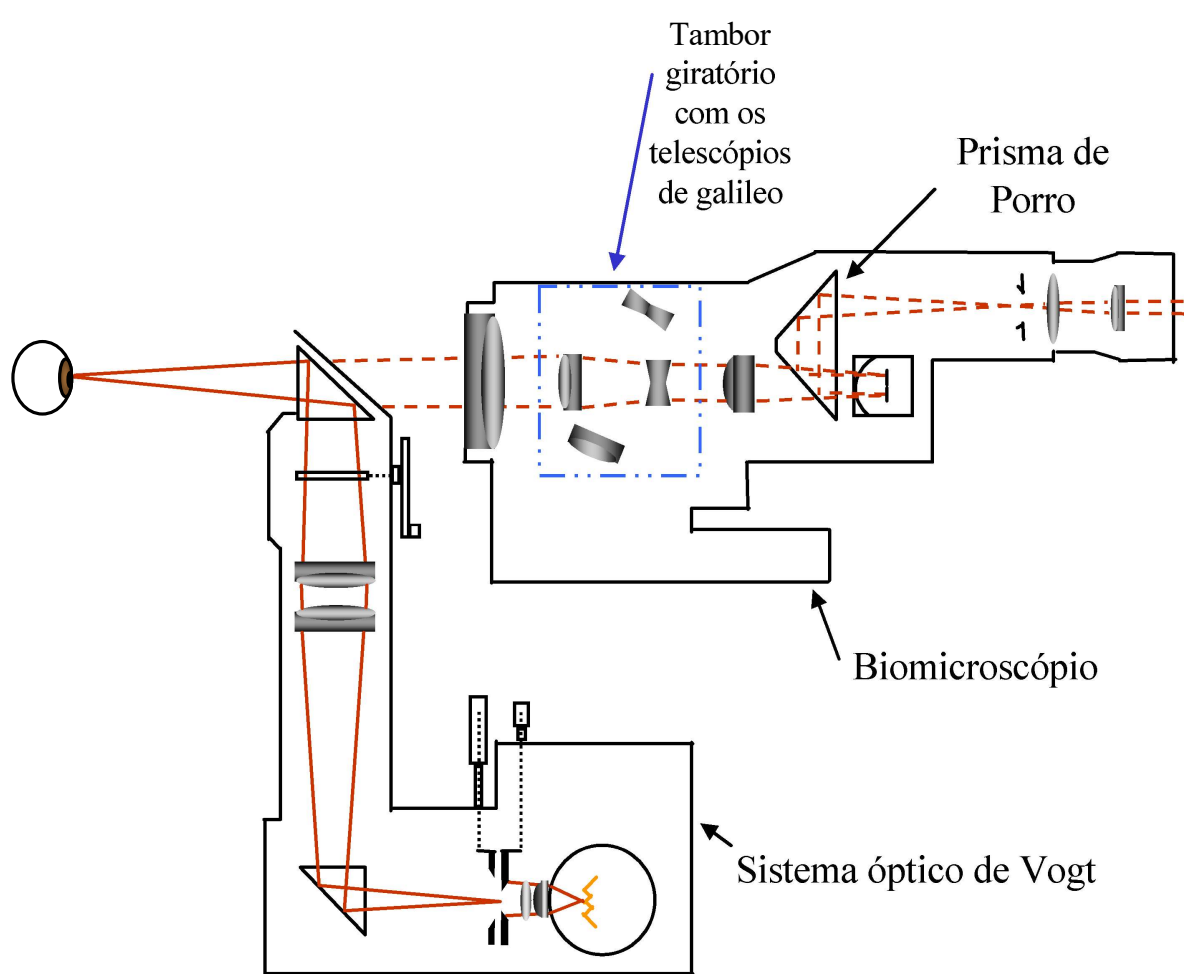

Figura 4.5: Desenho esquemático de uma lâmpada de fenda do tipo fabricada pela Carl Zeiss. O sistema de iluminação é colocado na parte inferior do equipamento. 


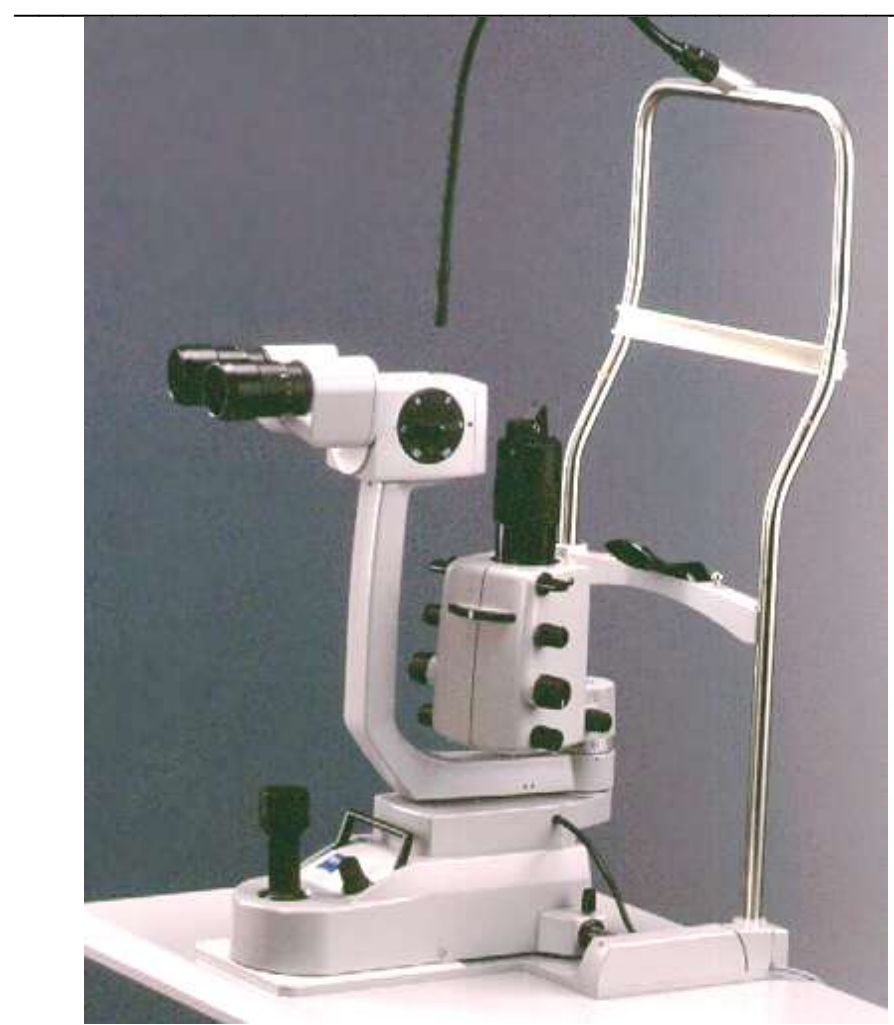

(a)

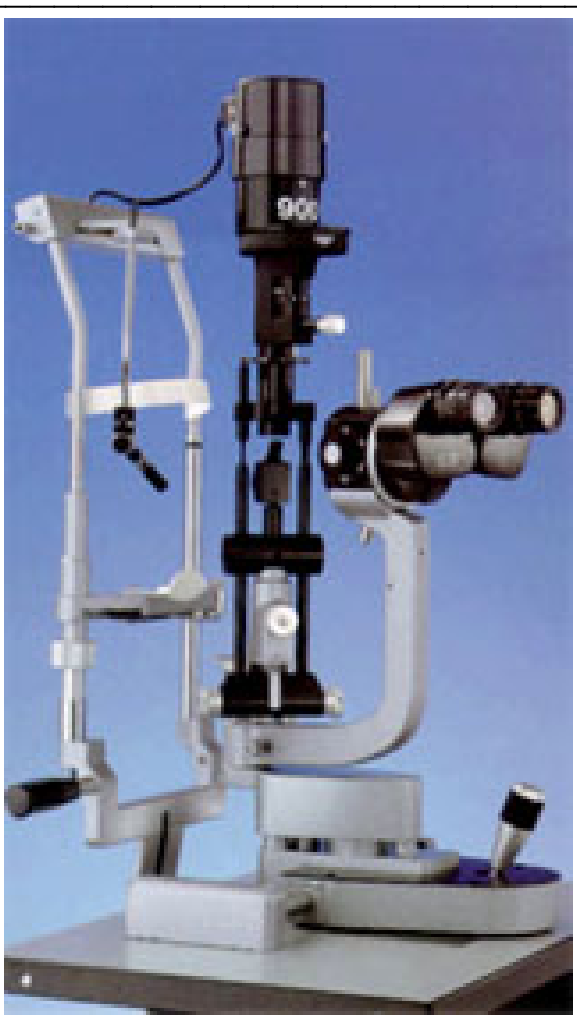

(b)

Figura 4.6: Lâmpada de Fenda (a) Carl Zeiss, com iluminação por baixo e (b) Haag Streit, com iluminação por cima.

Outra diferença entre estes dois tipos de Lâmpada de Fenda está no biomicroscópio. Na lâmpada da Carl Zeiss (grupo do qual a Topcon - nossa Lâmpada de Fenda - enquadra-se) existe o sistema de mudança do aumento pelo telescópio de Galileo, enquanto que na Haag Streit, a mudança no aumento é feito pela troca de lentes no caminho óptico. Isto é um diferencial importante, pois com o desenvolvimento tecnológico no processamento de imagens, a lâmpada da Carl Zeiss, leva vantagem para a aquisição de imagens pois, na saída do telescópio de Galileo os feixes de luz emergem paralelos, facilitando a introdução de divisores de feixe para desviar estes para uma câmera de vídeo e posteriormente a um computador, facilitando uma futura automação do equipamento. Na lâmpada Haag Streit, devido ao não paralelismo do feixe, a aquisição da imagem exige uma óptica extra e dedicada só para isto. 


\section{Capítulo 5 - Materiais e Métodos}

\subsection{Introdução}

Em nosso sistema foi utilizada a Lâmpada de Fenda da Topcon, modelo SL-7E. (figura 5.0), que possibilita a introdução de componentes óticos no caminho óptico de feixes paralelos.

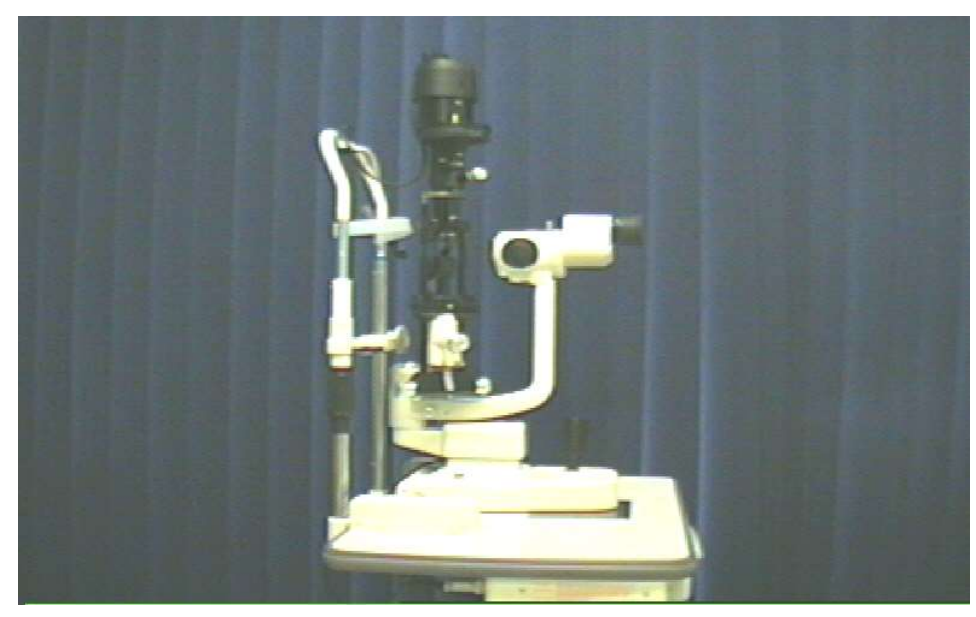

Figura 5.0: Lâmpada de Fenda Topcon SL-7E utilizada no sistema.

A figura 5.1 mostra um esquema do sistema desenvolvido.

Um anel luminoso em forma circular, composto por cerca de 15.000 fibras óticas, foi utilizado como a mira de projeção na córnea do paciente. $\mathrm{O}$ anel é acoplado à frente do sistema ótico da Lâmpada de Fenda.

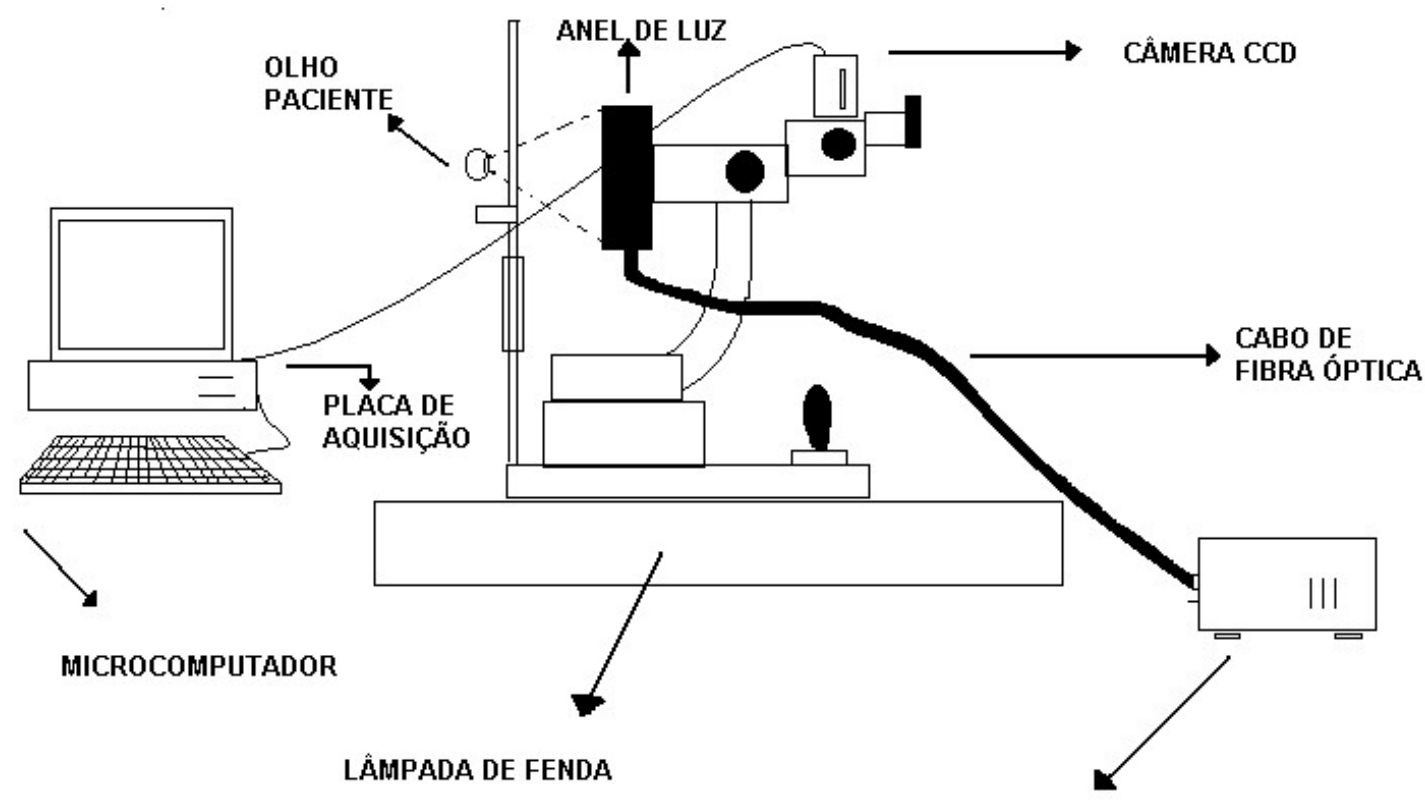

FONTE DE LUZ

Fig. 5.1 - Esquematização da Montagem Ceratômetro Automatizado 
Um separador de feixes comercial, composto por dois prismas, foi inserido no caminho ótico de feixes paralelos da Lâmpada de Fenda. O reflexo da mira projetada na córnea é, então, desviada em $40 \%$, por este separador de feixes, para um adaptador ótico, que por sua vez está acoplado a uma câmera de vídeo. A imagem é enviada a um micro computador do tipo PC, via uma placa de captura de vídeo comercial. Os $60 \%$ restantes dos feixes refletidos da córnea são direcionados às oculares da Lâmpada de Fenda, para que o clínico possa visualizar o olho simultaneamente nas oculares e no monitor do PC. Então, um software, desenvolvido no Laboratório de Física Oftálmica - FMRP-USP, analisa as imagens e fornece o raio de curvatura da córnea na região de projeção do anel.

Com o intuito de se poder realizar a ceratometria em duas outras regiões da córnea, senão a região central (região padrão de 3,0 - 4,0mm, onde a córnea é relativamente esférica) construiu-se um acoplador de lentes (as lentes da caixa de provas do "Greens" são utilizadas), cujo objetivo é simular miras de tamanhos diferentes, sem ter que lançar mão de construir (ou adquirir) novos anéis luminosos, que possuem relativo alto custo. Esse sistema permite a projeção de vários anéis na córnea, apenas introduzindo as lentes (figura 5.6) e variando-se o foco do sistema ao se acrescentarem as lentes, modificando assim, o tamanho das miras, que continuam sendo miras fixas para cada situação. Neste caso, a imagem das oculares está fora de foco e o clínico deve ajustar o sistema através do monitor do PC. Estas são medidas adicionais (para a medida convencional, o sistema está em foco simultaneamente nas oculares e monitor), e só podem ser comparadas com a curva teórica inserida no programa (vide capítulo 6 sobre o software desenvolvido), pois não existem sistemas comerciais que ofereçam tal análise.

Desta forma, os componentes que constituem nosso sistema são: Lâmpada de Fenda, anel luminoso, divisor de feixes, adaptador ótico, acoplador de lentes, fonte luminosa (110/220V), câmera de vídeo CCD (charged coupled device), placa de captura de vídeo e um PC Pentium, 166MHz, 32Mb de memória RAM.

Os componentes estão descritos detalhadamente a seguir. 


\subsection{O Sistema Ótico}

\subsection{1 - Anel Luminoso}

O Anel Luminoso é composto por aproximadamente 15000 fibras óticas que estão ligadas a uma fonte de luz. A fonte é composta por um circuito eletrônico 110/220V com potência regulável, 2 lâmpadas de $150 \mathrm{~W}$ e por um sistema interno de refrigeração (figura5.2a). A potência das lâmpadas pode ser ajustada de tal modo a permitir a projeção do anel com nitidez no olho do paciente, ou seja, com confluência.

A figura5.2b mostra o anel adaptado à Lâmpada de Fenda.

(a)

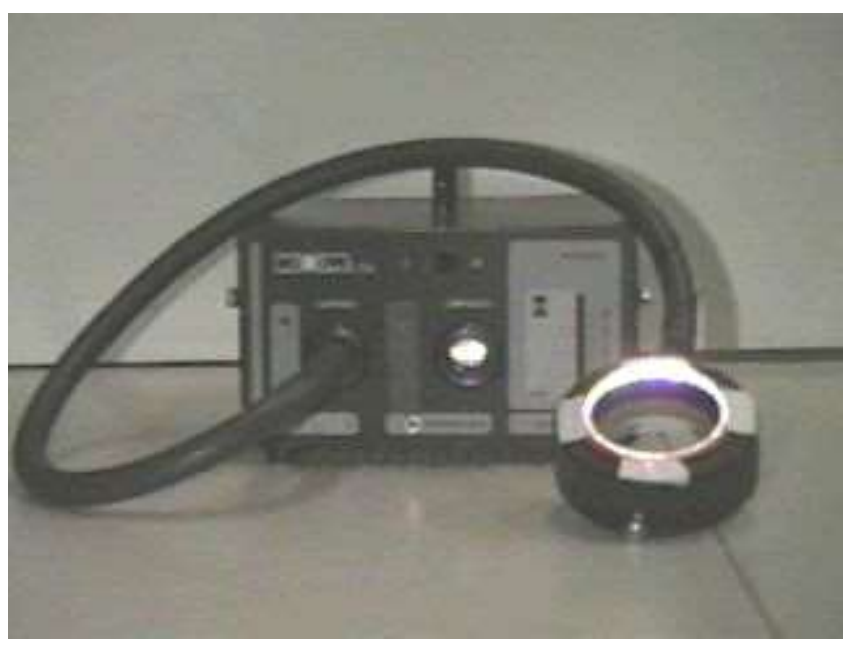

(b)

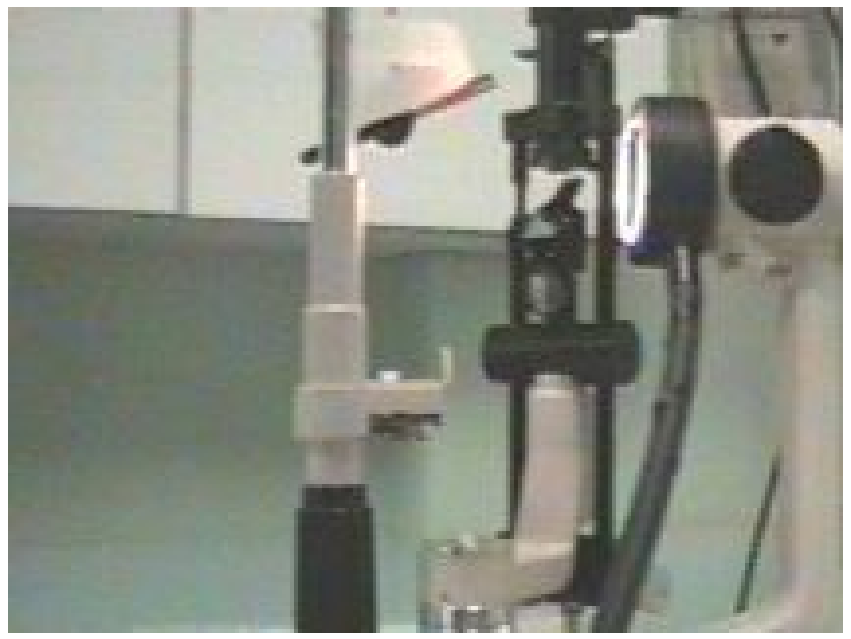

Figura 5.2: Foto das partes do sistema: (a) Fonte Luminosa, Fibra Óptica e Anel Luminoso; (b)Acoplamento do Anel Luminoso à Lâmpada de Fenda. 


\subsection{2 - O Separador de Feixes e o Adaptador Ótico para CCD}

O separador de feixes juntamente com o adaptador ótico são os componentes óticos responsáveis pelo acoplamento entre a Lâmpada de Fenda e a câmera de vídeo CCD.

O separador de feixes é composto internamente por 2 prismas, e é facilmente encontrado no mercado com características próprias e compatíveis para cada tipo específico de Lâmpada de Fenda. O mesmo é inserido no caminho ótico onde os feixes de luz são paralelos, não alterando dessa maneira a imagem que está sendo visualizada pelo operador, apenas altera a direção de parte do feixe, enviando $40 \%$ ao CCD e os $60 \%$ restantes às oculares da Lâmpada de Fenda, onde se encontra o examinador.

A junção destes dois componentes óticos (separador de feixes + adaptador ótico), é responsável pela formação da imagem no CCD e também pelo ajuste da intensidade de luz proveniente da reflexão sobre a córnea, já que o adaptador ótico é acrescido de um diafragma ajustável manualmente.

A figura 5.3 mostra os dois componentes citados.

(a)

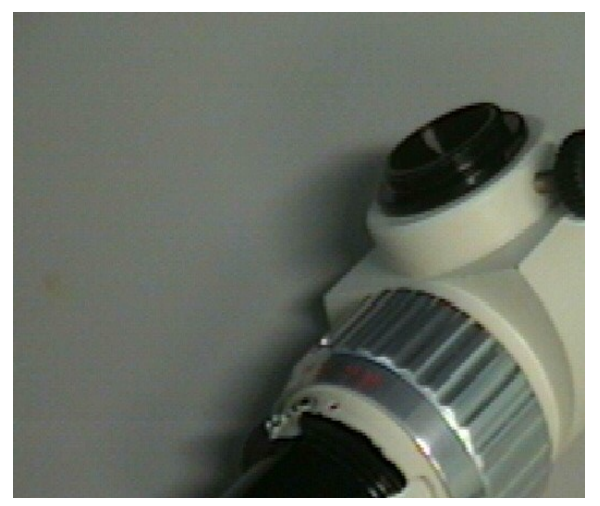

(b)

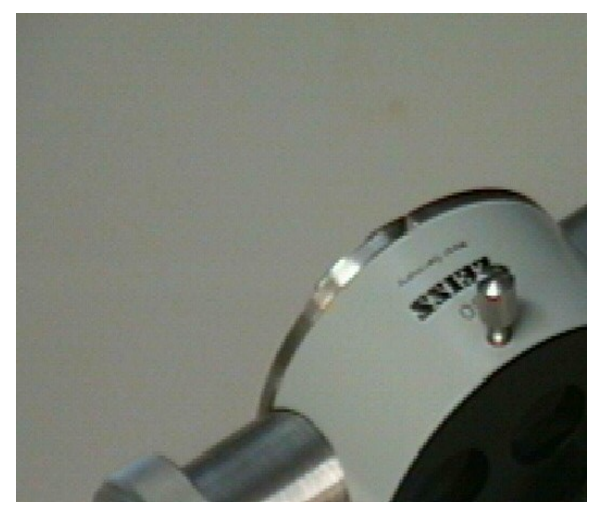

Figura 5.3: (a) Adaptador ótico para imagem em LF no CCD ; (b) Separador de feixes.

\subsection{3 - O Acoplador de Lentes}

O acoplador de lentes foi projetado e, então, construído na oficina mecânica do Departamento de Física e Matemática da USP de Ribeirão Preto. Constitui-se basicamente de um cilíndro em alumínio, com aberturas para inserção de lentes (fenda 
transversal que permite o encaixe de até 2 lentes circulares justapostas de diâmetros de 40mm aproximadamente ) e extremidades padrão de adaptação em Lâmpada de Fenda. É posicionado entre o adaptador ótico e o separador de feixes (figura 5.4). Por ele, passam feixes de luz colimados (paralelos). A fig.5.5 mostra em detalhes o adaptador construído.

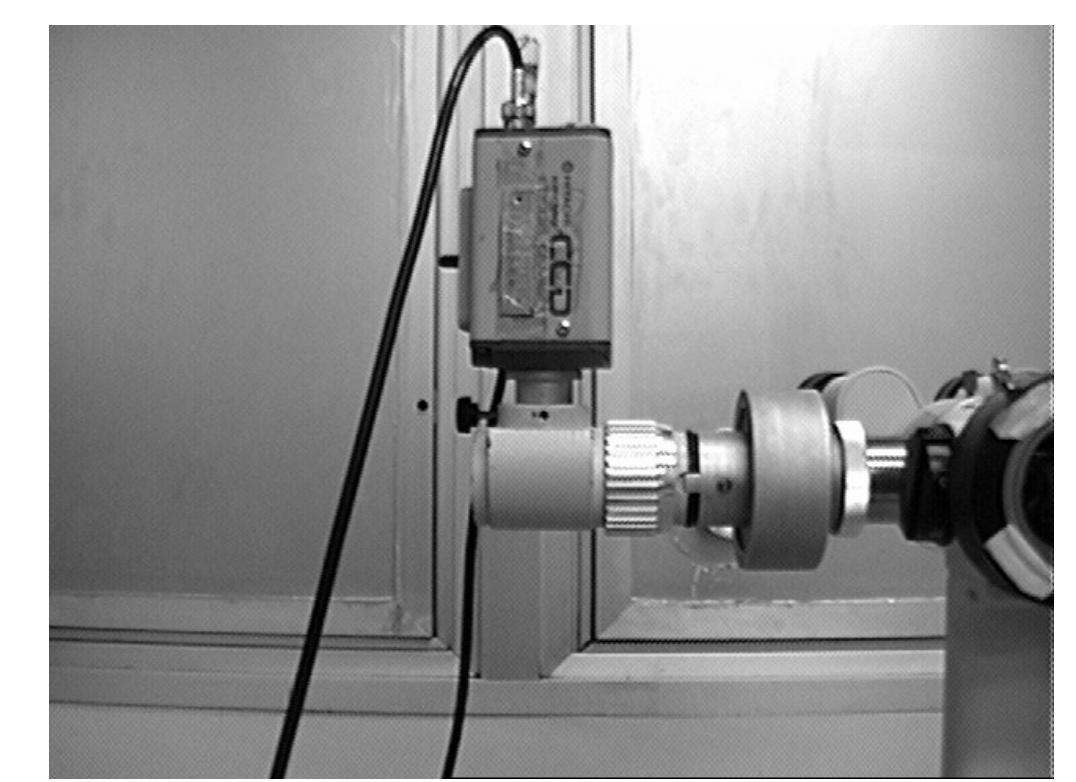

Fig. 5.4-Em detalhes a foto do acoplamento dos: divisor de feixes, adaptador ótico, acoplador de lentes e câmera CCD

O mecanismo de funcionamento baseia-se no fato de que, com o acoplamento da lente, altera-se o foco do sistema, e para o usuário focalizar novamente o anel terá que mudar a distância entre o olho e o anel, conseqüentemente mudando seu tamanho de projeção, permitindo uma análise de outras áreas da córnea do paciente, através da projeção de aneis de diâmetro distintos.

A projeção é realizada em três etapas. Primeiramente a imagem é projetada e então capturada mas sem o uso de lentes no acoplador (lente 0). Logo em seguida acopla-se uma lente de 2,25di e é feito o ajuste focal, obtendo-se uma nova imagem que também é capturada pelo sistema. Por fim ajusta-se agora uma nova lente de 5di, que permite a formação de um terceiro anel. 


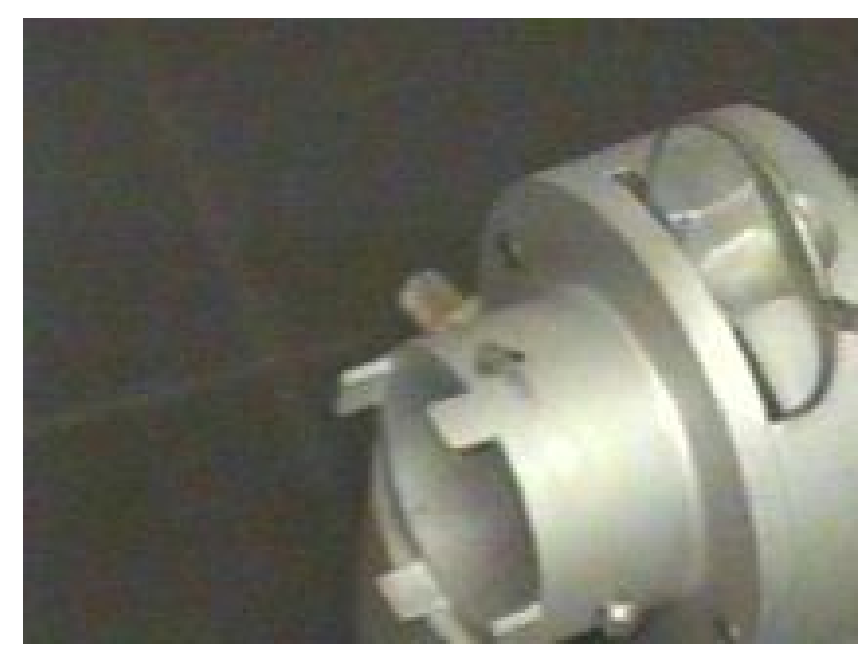

Fig. 5.5 - Acoplador de Lentes

Assim, a parte ótica de acoplamento à Lâmpada de Fenda, além do anel luminoso consiste no divisor de feixes, adaptador ótico e acoplador de lentes. A figura 5.5 mostra em detalhes esta parte do sistema, incluindo a câmera de vídeo. 


\subsection{Sistema de Detecção}

\subsection{1 - A Câmera CCD}

A câmera CCD utilizada foi a Hitachi KP-C550 (figura 5.6).

Este componente não foi considerado crítico para o desenvolvimento do sistema. As circunstâncias nas quais a captura da imagem ocorrem são favoráveis.

A luminosidade da cena é suficientemente alta para que não haja preocupação direta com a sensibilidade do aparelho.

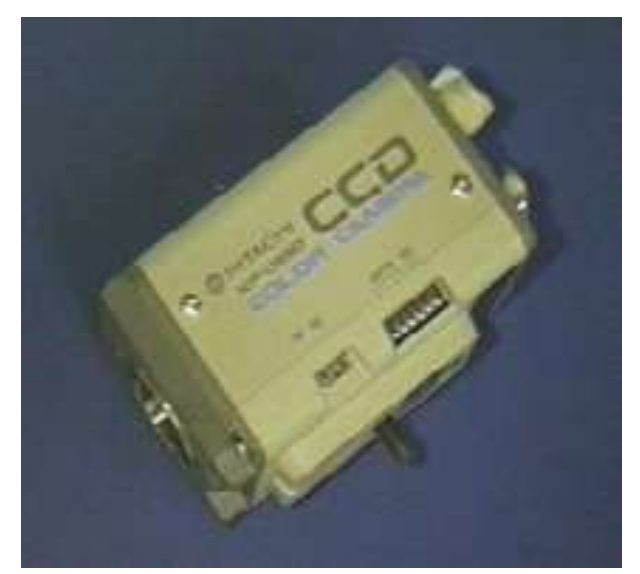

Fig 5.6 - Câmera CCD HITACHI KP-C550 usada no projeto

A resolução da CCD também não é crítica, uma vez que a resolução do sistema será limitada pelo padrão de vídeo escolhido (NTSC). Assim, a escolha desse componente esteve apoiada principalmente em sua compatibilidade com a ótica envolvida e em seu preço. Suas características estão na tabela 5.I.

\begin{tabular}{|cc|}
\hline & Hitachi KPC-550 \\
\hline Sensibilidade & 3,0 lux \\
\hline Área de detecção & $6,4(\mathrm{H}) \times 4,8(\mathrm{~V}) \mathrm{mm}$ \\
\hline Relação sinal/ruído & $40 \mathrm{~dB}$ \\
\hline Número de linhas & 430 linhas de TV \\
\hline
\end{tabular}

Tabela 5.1: Características do detector CCD Hitachi KPC-550. 


\subsection{2 - A Placa Digitalizadora de Imagem}

A Placa Digitalizadora de Imagem é responsável pela interface entre o sinal de vídeo proveniente do $\mathrm{CCD}$ e o microcomputador. O fator de maior relevância que levou a escolha desta placa foi a disponibilização da imagem em tempo real com boa qualidade para ser posteriormente tratada. Para o ceratômetro a visualização da imagem em tempo real é de fundamental importância para o clínico.

Acrescenta-se ainda, o baixo custo, facilidade de aquisição e a padronização dos seus drivers que, enfim, contribuíram para sua escolha final. A placa que melhor se enquadrou nestas características e que viabilizou todo o sistema de captura das imagens de olhos fora a Meteor I da Matrox.

Assim, para o funcionamento do sistema, todos estes itens são acoplados à Lâmpada de Fenda, o anel luminoso é projetado na córnea do paciente e então focalizado pelo clínico, através do movimento manual da Lâmpada de Fenda. A figura 5.8 ilustra a imagem vista pelo clínico nas oculares e no monitor do PC simultaneamente.

Após este procedimento, o clínico seleciona o software de modo a obter o raio de curvatura da córnea naquela região de projeção do anel.

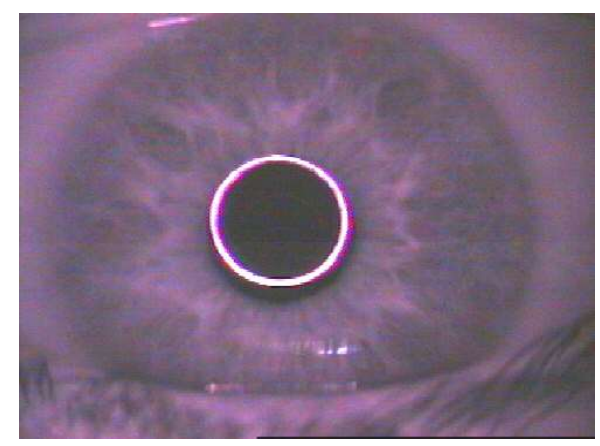

Figura 5.7: Imagem vista pelo clínico nas oculares e no monitor do PC simultaneamente, quando o anel luminoso está focalizado (esta imagem foi capturada com filtro de infravermelho para o conforto do paciente). 
A seguir, será descrito o software desenvolvido no Laboratório de Física Oftálmica - FMRP-USP para a determinação dos raios de curvatura da córnea. 


\section{Capítulo 6 - Fundamentos Teóricos ${ }^{[4],[20]}$}

\section{0 - Introdução}

Neste capítulo será descrito como determinar o raio de curvatura da córnea humana a partir da projeção de uma mira luminosa na mesma. Assim, várias considerações deverão ser feitas.

A córnea humana na realidade é um tecido avascularizado, possuindo propriedades mecânicas específicas. Tais propriedades definem a estabilidade da mesma, a qual por sua vez está correlacionada com a estrutura do estroma, com a conexão entre as camadas e ainda com a espessura ${ }^{[19]}$. Portanto, a córnea pode assumir diferentes formas, sendo extremamente difícil prever um modelo teórico que forneça uma sugestão completamente realística. Qualquer modelo apresentará pontos desfavoráveis. Cabe, então, a escolha do método que melhor se ajuste aos objetivos deste trabalho.

Consideremos a córnea como sendo um modelo de um espelho convexo, que forma uma imagem virtual da estrutura da fonte de luz. A imagem formada é projetada na córnea do paciente. Como já descrito nos capítulos precedentes, a córnea possui uma forma esférica somente na chamada zona ótica central. É, pois, de suma importância levarmos em consideração tais características, uma vez que as mesmas estarão estritamente relacionadas, ora a favor, ora contra, dependendo do modelo matemático que se escolhe para obtenção dos resultados.

Existe o chamado modelo esférico, onde a aproximação é muito boa para a região central da córnea ${ }^{[4]}$, mas devido ao aplainamento da córnea em direção à periferia, há de fato uma pequena discrepância nos resultados obtidos nesta região em comparação aos reais, uma vez que ao utilizarmos este modelo, estamos pressupondo que toda a córnea seja esférica, o que de fato não condiz com a realidade. 
Entretanto, para um estudo mais criterioso e preciso da periferia, existe o chamado modelo elíptico, onde a córnea é tida como um elipsóide, que tornam os resultados referentes à periferia mais próximos da realidade.

Os resultados apresentados pelo modelo elíptico diferem dos apresentados pelo modelo esférico, na área periférica, apresentando certa vantagem. Entretanto, geralmente os raios de luz incidentes sobre a periferia da córnea são obstruídos pela íris, não adentrando o olho. Portanto, esta região da córnea não interfere muito na visão do paciente, daí a maior importância a ser dada à zona ótica central, que por sua vez influenciou fortemente para que o modelo a ser escolhido fosse o esférico.

Entretanto, na escolha do modelo a ser utilizado para os cálculos, há de se analisar ainda o fator custo/benefício. Não se pretende analisar pormenoramente toda a topografia da córnea. Pretende-se apenas analisar especificamente a curvatura da região central corneana. O modelo esférico, além de sua simplificação, é também capaz de fornecer os resultados necessários e com precisão satisfatória para inteira realização deste trabalho.

\section{1 - Modelo Esférico}

No modelo esférico objetiva-se aproximar a superfície da córnea a uma esfera. Assim, a córnea se apresenta, teoricamente, como sendo um espelho convexo esférico.

$\mathrm{Na}$ verdade, o princípio que rege este modelo é bastante conhecido pelos fabricantes de ceratômetros convencionais, e é denominado "Princípio da Ceratometria".

A figura 6.0 ilustra o modelo a ser utilizado. 


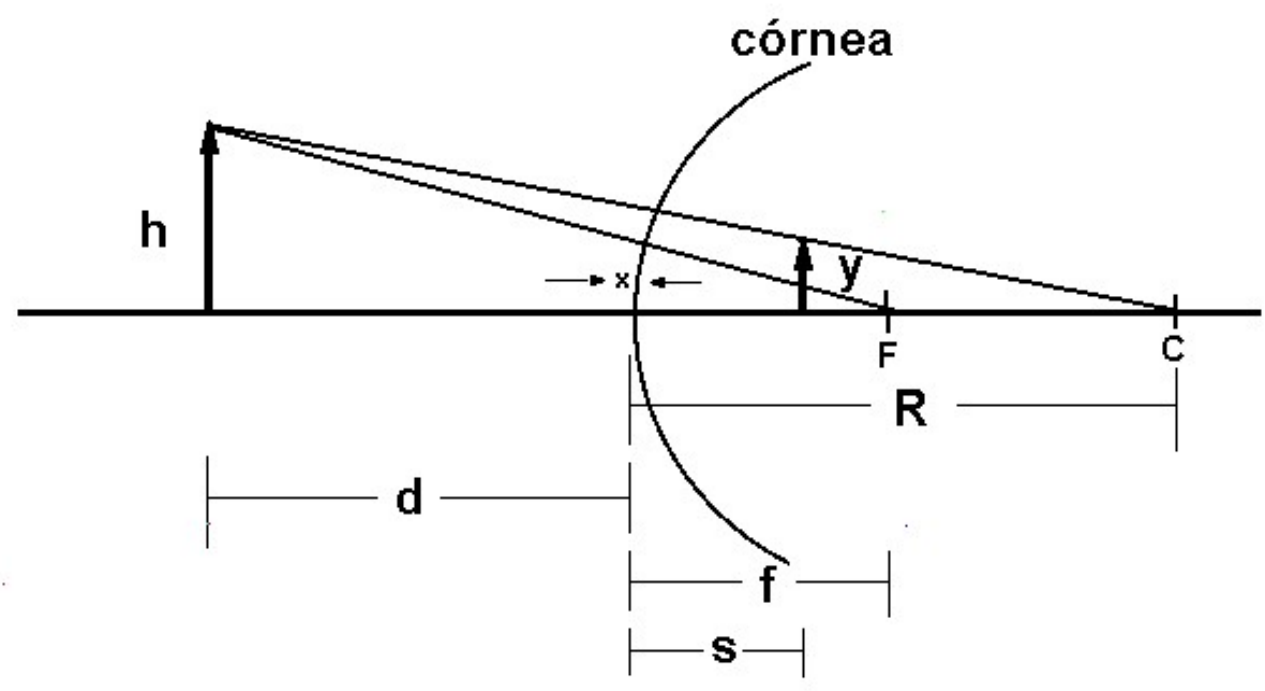

Fig. 6.0: Geometria do modelo esférico a ser utilizado.

Um objeto $h$ (alvo), é posicionado a uma distância $d$ da córnea. A reflexão forma uma imagem virtual de tamanho $y$ à uma distância $s$ da córnea. A distância $d$ entre a mira e o eixo da córnea é muito grande relativamente à distância focal da córnea $(f)$. Considerando que os feixes de luz provenientes de $\mathrm{h}$ fazem pequenos ângulos com o eixo ótico, pode-se considerar, com base nos dois argumentos acima, que a distância focal é a metade do raio de curvatura $(R)^{[20]}$. Então, analisando a figura e fazendo semelhança de triângulos, obtém-se:

$$
\frac{y}{h}=\frac{R-s}{R+d} \cong \frac{R-s}{d} \quad \text {,para } \mathrm{d}>>\mathrm{R}
$$

Ainda, para objetos distantes tem-se $\mathrm{S} \cong \mathrm{R} / 2$.

Então, resolvendo o sistema para o raio esférico, tem-se : 


$$
R=\frac{2 d}{h} y
$$

Observa-se, então, que o raio obtido é linearmente proporcional ao tamanho da imagem formada, sendo os parâmetros $d$ e $h$ mantidos sempre fixos. $\mathrm{O}$ raio de curvatura da córnea pode, então, ser obtido usando o princípio ceratométrico. A leitura apresentada nos ceratômetros comuns é geralmente expressa em termos da recíproca do raio de curvatura, que é conhecida como poder ótico ou poder de refração $(F)$, cuja unidade é expressa em dioptrias (di):

$$
F=\frac{n_{c}-1}{R}
$$

, onde $n_{c}$ é o índice de refração da córnea.

Esta fórmula paraxial estima o poder da superfície refrativa quando os raios incidentes são aproximadamente normais à córnea, e é válido somente para a zona apical. Entretanto, ela é aplicada para todos os pontos da córnea. [21]

Através da equação (2) nota-se que o valor de $R$ pode ser facilmente obtido. Entretanto, é possível ainda efetuar o cálculo do raio de curvatura com melhor precisão, realizando uma nova aproximação, que tornará esta equação mais precisa para os cálculos pretendidos.

Sabendo que para um espelho esférico $f=2 r$, obtém-se, então, a seguinte expressão (dedução no apêndice II):

$$
R=\frac{2 d h^{2}+2 y h \sqrt{d^{2}+h^{2}-y^{2}}}{\left(h^{2}-y^{2}\right)}
$$

comerciais.

Esta expressão é amplamente empregada nos ceratômetros 


\section{Capítulo 7 - O Software Desenvolvido}

\section{0 - Características Básicas}

No intuito de atender às necessidades do clínico que vai realizar uma ceratometria, o software deve apresentar algumas características básicas, tais como: proporcionar ao médico usuário facilidade na obtenção da ceratometria dos pacientes, precisão igual ou superior ao dos ceratômetros comerciais e rapidez das medidas. Assim, além de possuir confiabilidade e ser automático, deve ser amigável na interface com o usuário.

Para que o sistema fosse de fácil manuseio e de interface amigável com o usuário, utilizou-se o Delphi 32 da Borland ${ }^{[21]}$ para a programação.

O Delphi32 permite utilizar as rotinas do fabricante da placa digitalizadora, permite facilidade de programação e construção de ambiente com interface clara e objetiva com o usuário, sendo compatível com DOS/Windows95-98, que é o sistema operacional padrão no momento para PC's.

\section{1 - Rotinas e Desenvolvimento do Software}

O software pode ser subdividido em blocos, onde, cada bloco executa uma função bem determinada e essencial na obtenção do resultado final da ceratometria. Um esquema geral de como foi desenvolvido o software no Laboratório de Física Oftálmica - FMRP-USP está ilustrado na figura 7.1 


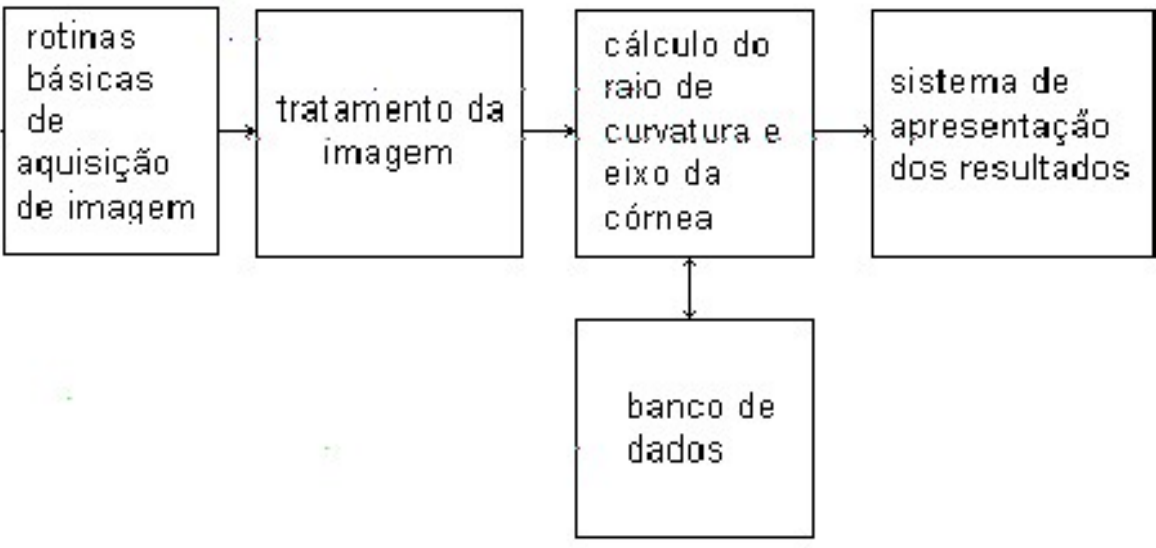

Figura 7.1- Esquema geral do software desenvolvido.

As Rotinas Básicas de Aquisição de Imagem são a base do software, pois fazem a interface do programa principal com a placa de captura e digitalização de imagens possibilitando o seu uso. Por exemplo, uma dessas rotinas alocam uma região da memória do $\mathrm{PC}$ e lá guardam a imagem digitalizada, que chega em quadros ("frames") e que são atualizados a cada 10ms dando a impressão de uma imagem em tempo real (ao vivo). Cabe ao software detectar o momento em que o usuário aciona o pedal (vide item 7.2) para "congelar" a imagem, que nada mais é do que aproveitar-se de um desses quadros, possibilitando sua utilização.

O Tratamento da Imagem consiste em obter, a partir da imagem adquirida, o anel referente ao reflexo a ser estudado e possibilitar suas medidas. Para isso utilizou-se técnicas já muito bem detalhadas de processamento de imagens, que são o "threshold" que consta de um sistema que impõe um limiar à imagem, onde esse limiar será o corte para determinar se dada informação é relevante ou é fruto de ruídos, e a segmentação, que é responsável pela determinação quantitativa da imagem, encontrando suas bordas e limites, possibilitando cálculos quanto às suas medias.

O Cálculo do Raio de Curvatura e a Determinação do Eixo da Córnea é composta pelo cálculo do centro de massa da figura tratada, e posterior cálculo das distâncias de cada ponto da borda do anel até este ponto, lembrando-se que essa 
distância é calculada inicialmente em pixels e depois transformada em milímetros utilizando-se as constantes que serão obtidas na calibração do sistema. Com isso, poder-se-á construir uma matriz com duas dimensões, uma contendo o ângulo de cada ponto da borda do anel (considerando-se como referencial o ' 0 ' grau trigonométrico) e outra para o raio calculado no respectivo ângulo. Com essa matriz, pode-se então calcular o raio médio em toda circunferência do reflexo de anel, e detectar possíveis variações significativas que podem ser interpretadas como deficiência na esfericidade da córnea.

O Banco de Dados deste sistema já foi citado acima quanto aos seus objetivos, será composto de um banco de imagens associadas à tabelas com informações do paciente, da consulta, da patologia em questão e o médico que fez a assistência. Importante ressaltar que esse banco pode ser muito útil, visto que se trata de um Hospital Escola onde o interesse acadêmico pode justificar o armazenamento de informações úteis na didática médica, além do que trata-se da oportunidade do médico/professor poder compartilhar as imagens antes exclusivas para quem fazia o exame, com os alunos e até mesmo com os pacientes.

Para o Sistema de Apresentação dos Resultados deve-se levar em consideração a objetividade e a precisão do exame, ou seja, o resultado final deve estar nos mesmos padrões dos que são lidos nos ceratômetros convencionais, para facilitar a interpretação do médico, com a vantagem de que, com o monitor como interface de saída, pode-se demonstrar graficamente e numericamente os parâmetros relevantes para um bom exame. Além disso deve-se ressaltar a facilidade no uso do sistema, onde a medida pode ser feita observando-se alguns passos:

Quando se inicia o programa, a imagem vista na lâmpada de fenda será concomitantemente mostrada "ao vivo" na tela, basta escolher o foco e o momento certo para congelar a imagem (figura 7.2) 
Após isso, basta ao usuário dizer, através de uma lista de opções qual a lente usada na captura, (figura 7.2). E em seguida clicar no botão "Calcula", que o programa automaticamente faz o cálculo dos raios de curvatura da córnea.

Para imprimir os resultados, o usuário pode escolher se quer imprimir todos os dados, com gráfico e desenho do anel na córnea, ou simplesmente o laudo simples como se fosse no auto refrator. Para se fazer a análise dos dados, basta clicar no botão de análise que aparece a figura 7.4 com os dados referentes à córnea estudada.

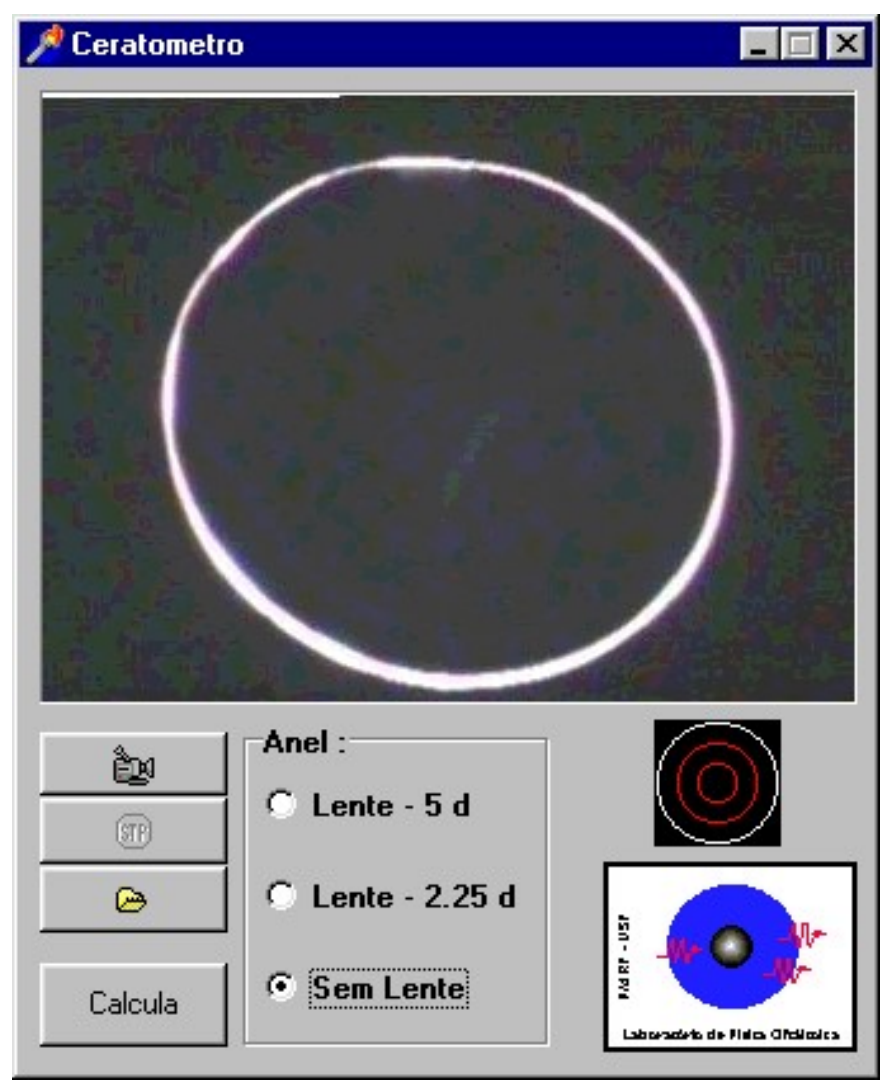

Figura 7.2- Tela Principal do software desenvolvido. 
O Software

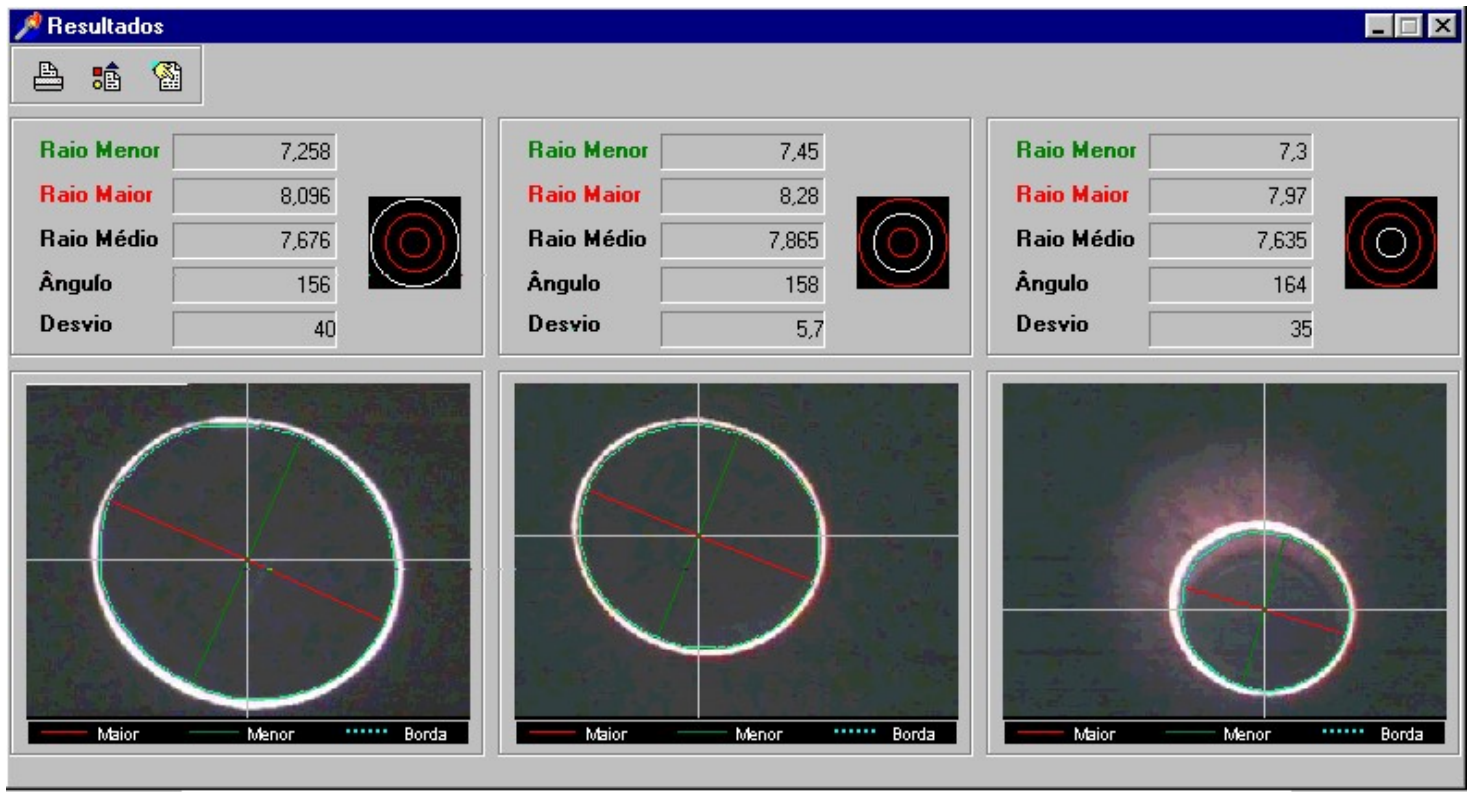

Figura 7.3- Tela de Resultados do software desenvolvido. 


\section{Análise}
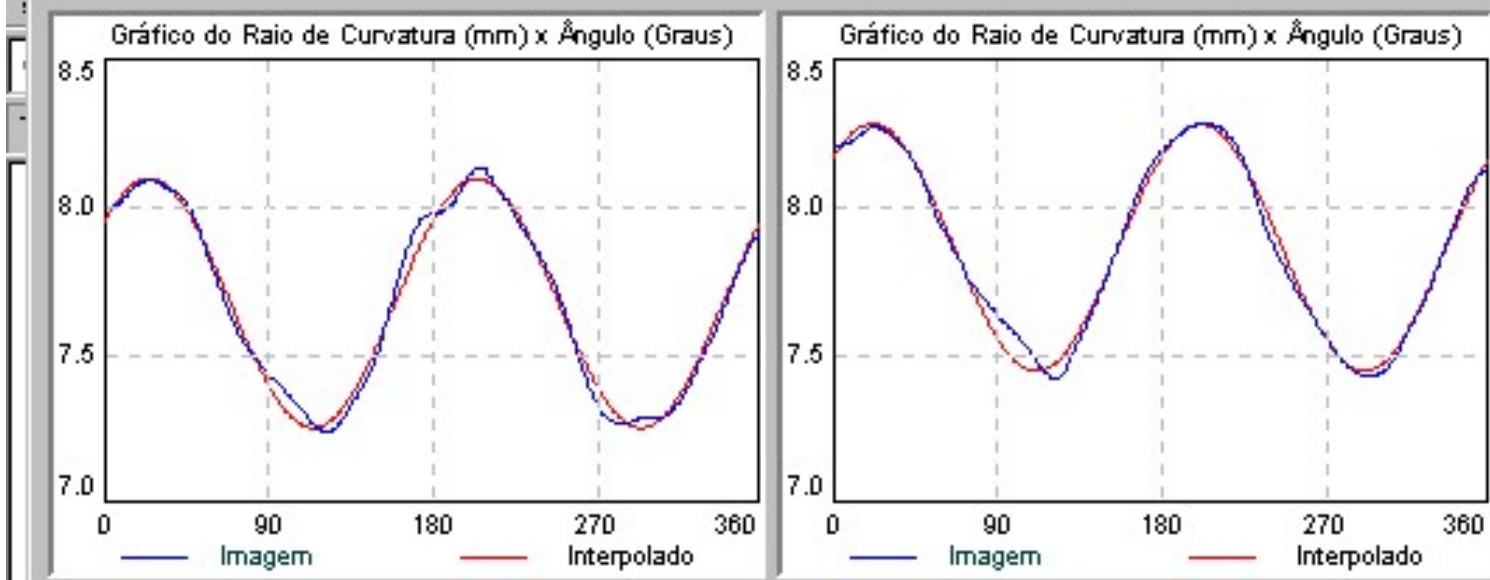

\section{曷 吘 䊀}

\begin{tabular}{|c|c|}
\hline Raio Menor & 7.258 \\
\hline Raio Maior & 8,097 \\
\hline Raio Médio & 7,677 \\
\hline Ângulo & 156 \\
\hline
\end{tabular}

Fig. 7.4 - Tela de Resultados acrescida de análise gráfica 


\section{2 - Acessórios}

\section{Pedal para Aquisição de Imagem}

Um pedal para aquisição de imagem (alternativo ao teclado e mouse do PC) foi adaptado ao sistema para facilitar ao clínico a captura da imagem quando este está utilizando ambas as mãos para exame no paciente ou que não deseja afastar seus olhos das oculares da Lâmpada de Fenda para focalização da mira através do monitor.

Tal monitoramento do pedal é feito usando-se componente apropriado para Delphi32 que possui rotinas de acesso à porta serial do $\mathrm{PC}^{[23]}$.

\section{Banco de Dados}

O Banco de Dados é um item complementar que permite ao clínico organizar seus prontuários, agendar consultas, cadastrar pacientes, criar uma banco de imagens do paciente, etc. 


\section{Capítulo 8 - O Sistema de Calibração}

Para que o sistema possa apresentar confiabilidade nos resultados, necessita-se de ser calibrado com superfícies cujos raios de curvatura são conhecidos e precisos.

O sistema de calibração foi construído com base em esferas de aço (esferas de rolamentos que apresentam precisão de $0,0005 \mathrm{~mm}$ em seus diâmetros) de diâmetros variáveis entre $3-17 \mathrm{~mm}$, de modo a simular os diâmetros reais e também diâmetros extrapolados de uma córnea humana [4], [24]

A figura 8.1 mostra o aparato de calibração utilizado.

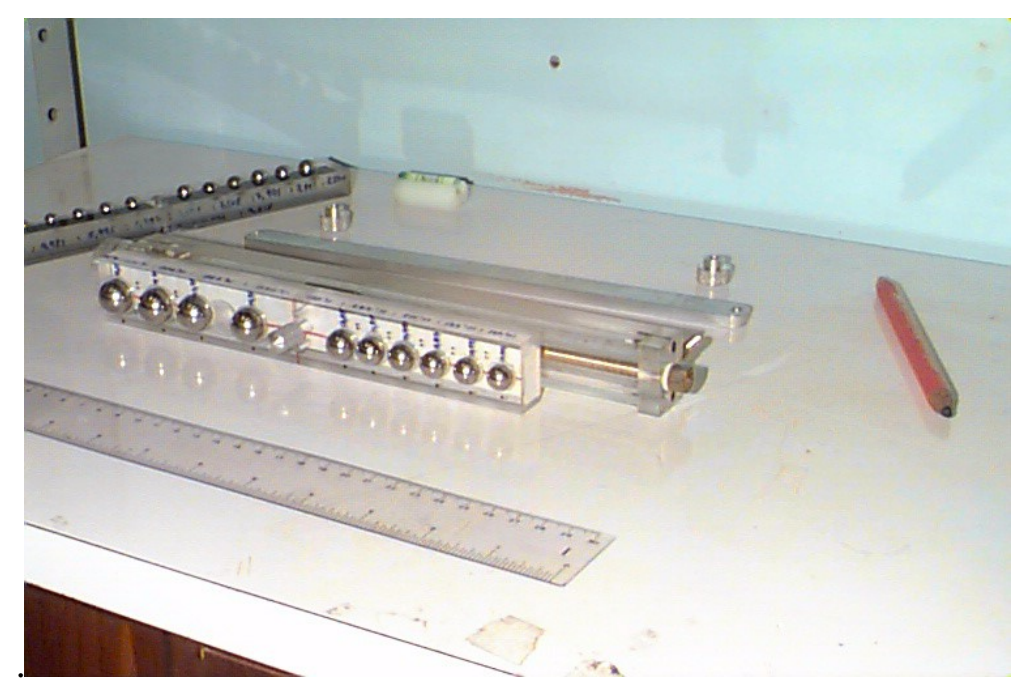

Fig 8.1- Aparato de calibração com esferas de aço.

A figura 8.2 mostra o aparato adaptado à Lâmpada de Fenda para calibração. 


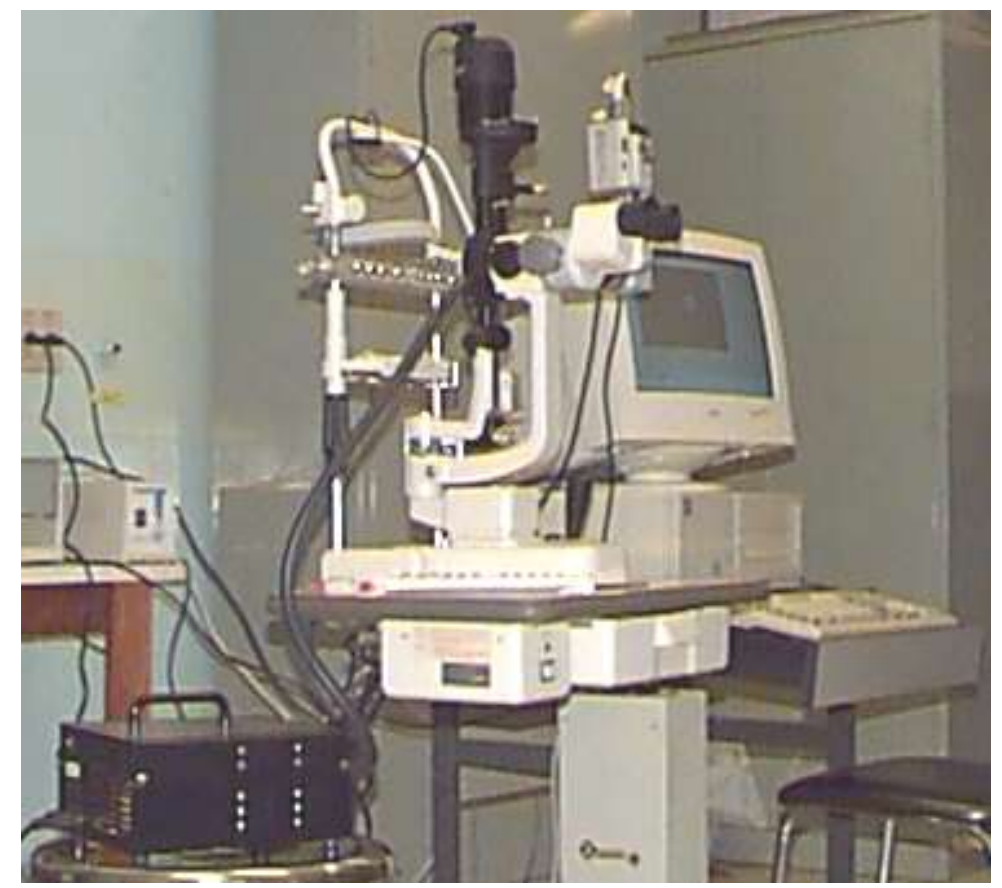

Fig 8.2 - Vista de todo o sistema de medida de curvatura da córnea no

\section{Laboratório de Física Oftálmica sendo calibrado- ( HC - USP)}

Um fator importante a ser considerado neste sistema desenvolvido é a magnificação da Lâmpada de Fenda a ser utilizada para as medidas.

A questão da profundidade focal é de suma importância, pois toda a matemática do sistema depende de seu valor numérico.

A lâmpada de fenda possui variados aumentos (6x, 10x, 16x, 25x e 40x) e independente da magnificação o objeto é focalizado a $100 \mathrm{~mm}$. Porém, para a visão humana, um pequeno deslocamento axial do sistema, ou seja, uma pequena desfocalização da imagem não é percebida, devido à capacidade de acomodação visual que o olho humano possui. Desta forma, a desfocalização se torna bastante sutil para pequenas magnificações da imagem, fazendo com que a Lâmpada de Fenda não esteja posicionada a $100 \mathrm{~mm}$ exatamente do objeto e, portanto, 
introduzindo erro no raio de curvatura (tamanho de imagem alterado devido à distância alterada entre objeto e Lâmpada de Fenda).

Verificou-se, então, que para uma manipulação da imagem com maior precisão para determinação focal, o aumento de 40x é o que melhor se adequa a esse requisito. Para este aumento uma pequena variação no deslocamento da L.F. provoca uma drástica desfocalização da imagem.

Para quantificar o erro obtido para cada aumento da Lâmpada de Fenda, utilizou-se uma esfera qualquer (raio $=13.050 \mathrm{~mm}$ ) e mediu-se a distância que a objetiva encontrava-se do objeto várias vezes. Deste forma, pode-se perceber pela Tabela 8.1 o desvio encontrado para cada magnificação.

Tabela 8.1: Erros obtidos para focalização em Lâmpada de fenda para aumentos variados*

\begin{tabular}{|c|c|c|c|l|l|l|l|l|l|l|}
\hline $\begin{array}{l}\text { Au } \\
\text { men }\end{array}$ \\
to
\end{tabular}

* Na tabela está adicionada os 41 mm que fornece a distância real entre a objetiva e o objeto. 
Como pode ser observado pela tabela 8.1, o menor erro na focalização do objeto é para o aumento 40 da Lâmpada de Fenda, assim sugere-se ao clínico que utilize este aumento para realizar a ceratometria.

Assim que a posição para a operação da Lâmpada de Fenda para a ceratometria foi definida, então o sistema foi calibrado em função desta magnificação. Procedeu-se do seguinte modo:

Foram efetuadas medidas em 23 esferas distintas, em aumento 40x da Lâmpada de Fenda, e para as três situações: sem lente no adaptador e com lentes (02) no adaptador. Desta forma, para cada esfera eram realizadas 3 medidas distintas. Ainda para se obter uma média para eliminar erros intrínsecos de medidas ou sistemáticos foi realizado a mesma medida $3 \mathrm{X}$ para cada esfera em cada situação.

Como nesta situação eram conhecidos, além de $d$ (distância entre o objeto e a imagem), $h$ (dimensão do anel luminoso - objeto), também o $R$ (raio de curvatura da esfera), referentes à expressão 6.4 (repetida abaixo), foi possível determinar o $y$, ou seja, a dimensão da imagem em função de seu raio de curvatura e então, obter a relação pixel $/ \mathrm{mm}$ para as medidas em olho humano posteriormente.

$$
R=\frac{2 d h^{2}+2 y h \sqrt{d^{2}+h^{2}-y^{2}}}{\left(h^{2}-y^{2}\right)}
$$

Substituindo os valores em 6.4, obtemos: 


$$
R=\frac{2(100)(25)^{2}+2 y(25) \sqrt{100^{2}+25^{2}-y^{2}}}{\left(25^{2}-y^{2}\right)}
$$

Como $y$ é medido em pixels, temos agora:

$$
\mathrm{y}=\mathrm{y}^{\prime} * \mathrm{C}_{0 \mathrm{~mm} / \text { pixel }}
$$

E a expressão (8.1) torna-se:

$$
R_{n}=\frac{125000+50 y_{n}{ }^{\prime} C_{0} \sqrt{10625-y_{n}{ }^{\prime 2} C^{2}{ }_{0}}}{\left(625-y_{n}{ }^{\prime 2} C^{2}{ }_{0}\right)}
$$

Teremos uma constante distinta para cada tipo de aumento (lente 0di, lente 225di e lente 5di):

$$
\begin{aligned}
& \operatorname{Co}(0)=0,004702 \\
& \operatorname{Co}(225)=0,005897 \\
& \operatorname{Co}(5)=0,007597
\end{aligned}
$$

Substituindo teremos: 
$R_{n(0)}=\frac{125000+50 y_{n(0)}^{\prime} 0,004702 \sqrt{10625-y_{n(o)}^{\prime}{ }^{2}(0,004702)^{2}}}{\left(625-y_{n(0)}^{\prime}{ }^{2}(0,004702)^{2}\right)}$

$R_{n(225)}=\frac{125000+50 y_{n(225)}{ }^{\prime}(0,005897) \sqrt{10625-y_{n(225)}{ }^{\prime 2}(0,005897)^{2}}}{\left(625-y_{n(225)}{ }^{\prime 2}(0,005897)^{2}\right)}$

$R_{n(5)}=\frac{125000+50 y_{n(5)}{ }^{\prime}(0,007597) \sqrt{10625-y_{n(5)}{ }^{\prime 2}(0,007597)^{2}}}{\left(625-y_{n(5)}{ }^{\prime 2}(0,007597)^{2}\right)}$

Teremos por fim os valores de y para cada aumento distintamente, pois os valores dos raios das esferas de calibração já são todos conhecidos.

Assim sendo, foram realizadas medidas em olhos humanos, que estão apresentadas a seguir. 


\section{Capítulo 9 - Resultados}

Feita a calibração do sistema desenvolvido, vários olhos humanos foram testados e seus resultados comparados a sistemas comerciais do Hospital das Clínicas de Ribeirão Preto.

Realizaram-se exames em olhos humanos pertencentes a estudantes voluntários da USP. Foram analisados 20 olhos, onde não foi feita aqui discriminação quanto ao sexo ou idade. A intensidade de luz do anel luminoso foi ajustada de forma a não ser incômoda ao paciente (este fato garante que a córnea e o olho humano não estão sendo prejudicados pela luz), e ao mesmo tempo apresentar confluência na imagem do anel.

Os pacientes foram submetidos a três sistemas de medição: 1. Nosso Sistema, 2. Ao sistema de ceratometria do Auto-Refrator Topcon, e ao ceratômetro manual convencional Bausch e Lomb, ambos pertencentes ao ambulatório de oftalmologia do $\mathrm{HC}-\mathrm{FMRP}$.

Vale a pena dizer que as medidas a serem comparadas entre o nosso sistema e os equipamentos comerciais são somente as medidas em que as lentes adicionais não são introduzidas no adaptador, ou seja, para o tamanho de mira padrão. As duas outras miras, de dimensões distintas, que o nosso sistema permite projetar no olho, são exclusividade de nosso sistema e apenas podem ser comparadas aos gráficos de análise apresentados na figura 7.4, do capítulo 7. Desta forma, o clínico pode ter uma idéia de quanto irregular está o astigmatismo em relação ao astigmatismo regular naquelas outras regiões, fornecendo inclusive os eixos de maior e menor poderes de refração, mesmo que não estejam a $90^{\circ}$ entre si, com o já visto no capítulo 7. 
Aliás, os ceratômetros manuais apenas apresentam resultados para astigmatismos regulares.

A tabela 9.1 mostra os valores de raios de curvatura obtidos para os três sistemas de ceratometria, para cada um dos voluntários.

Tabela 9.1 - Valores dos Raios de Curvatura Corneanos de Pacientes Voluntários Obtidos em Três Sistemas - Comerciais: Topcon e Baush Lomb; Nosso Sistema (NS). O raios maiores e menores referem-se aos raios de curvatura dos eixos principais do astigmatismo corneano.

\begin{tabular}{|c|c|c|c|c|c|c|c|c|c|}
\hline \multirow[t]{2}{*}{$\begin{array}{l}\text { Paci } \\
\text { ente }\end{array}$} & \multicolumn{3}{|c|}{ Raio Maior (mm) } & \multicolumn{3}{|c|}{ Raio Menor (mm) } & \multicolumn{3}{|c|}{ Ângulo* $\left({ }^{0}\right)$} \\
\hline & $\begin{array}{l}\text { Bausch } \\
\text { - Lomb }\end{array}$ & Topcon & NS & $\begin{array}{l}\text { Bausch } \\
\text { - Lomb }\end{array}$ & Topcon & NS & $\begin{array}{l}\text { Bausch } \\
\text { - Lomb }\end{array}$ & Topcon & NS \\
\hline 1 & 8.810 & 8.810 & 9.037 & 8.720 & 8.720 & 8.817 & 141 & 141 & 149 \\
\hline 2 & 8.890 & 8.890 & 9.010 & 8.710 & 8.710 & 8.594 & 121 & 121 & 116 \\
\hline 3 & 8.132 & 8.110 & 8.271 & 7.941 & 8.070 & 8.111 & 150 & 178 & 156 \\
\hline 4 & 8.030 & 8.110 & 8.014 & 7.941 & 8.060 & 7.882 & 130 & 171 & 159 \\
\hline 5 & 8.221 & 8.190 & 8.197 & 7.618 & 7.580 & 7.521 & 163 & 164 & 159 \\
\hline 6 & 8.134 & 8.170 & 7.976 & 7.714 & 7.510 & 7.505 & 105 & 92 & 96 \\
\hline 7 & 8.654 & 8.60 & 8.375 & 8.437 & 8.28 & 8.062 & 134 & 164 & 168 \\
\hline 8 & 7.785 & 7.750 & 7.559 & 7.627 & 7.520 & 7.387 & 170 & 160 & 160 \\
\hline 9 & 7.973 & 7.680 & 7.492 & 7.714 & 7.550 & 7.387 & 169 & 162 & 165 \\
\hline 10 & 7.767 & 7.770 & 7.805 & 7.627 & 7.610 & 7.382 & 162 & 173 & 175 \\
\hline
\end{tabular}

A tabela 9.2 traz os valores, em porcentagem, de discrepância nas medidas entre o nosso sistema e os sistemas comerciais automático (Topcon) e manual (Baush-Lomb).

\footnotetext{
* Os valores dos ângulos são sempre apresentados de $0^{\circ}-180^{\circ}$, de modo que $0^{\circ}$ e $180^{\circ}$ são equivalentes.
} 
Tabela 9.2 - Valores, em porcentagem, de discrepância nas medidas entre o nosso sistema (NS) e os sistemas comerciais automático (Topcon) e manual (Baush-Lomb)

\begin{tabular}{|c|c|c|c|c|c|c|}
\hline \multirow[t]{2}{*}{$\begin{array}{l}\text { Paci } \\
\text { ente }\end{array}$} & \multicolumn{2}{|c|}{$\begin{array}{c}\text { Erro relativo de NS } \\
\text { para o Raio Maior (\%) }\end{array}$} & \multicolumn{2}{|c|}{$\begin{array}{c}\text { Erro relativo de NS para } \\
\text { o Raio Menor (\%) }\end{array}$} & \multicolumn{2}{|c|}{$\begin{array}{c}\text { Erro relativo de NS para } \\
\text { o Eixo do Astigmatismo } \\
(\%)\end{array}$} \\
\hline & $\begin{array}{c}\text { Bausch - } \\
\text { Lomb }\end{array}$ & Topcon & $\begin{array}{c}\text { Bausch - } \\
\text { Lomb }\end{array}$ & Topcon & $\begin{array}{c}\text { Bausch - } \\
\text { Lomb }\end{array}$ & Topcon \\
\hline 1 & 2.58 & 2.58 & 1.11 & 1.11 & 5,6 & 5,6 \\
\hline 2 & 1.34 & 1.34 & 1.33 & 1.33 & 4,13 & 4,13 \\
\hline 3 & 1.71 & 1.98 & 2.269 & 0.51 & 4 & 12 \\
\hline 4 & 0.20 & 1.18 & 0.743 & 2.21 & 22 & 7.02 \\
\hline 5 & 2.40 & 0.08 & 1.27 & 0.78 & 2.45 & 3.05 \\
\hline 6 & 1.94 & 2.37 & 2.71 & 0.066 & 8.57 & 4.35 \\
\hline 7 & 3.22 & 2.616 & 4.44 & 2.633 & 10.44 & 2,43 \\
\hline 8 & 2.90 & 2.46 & 3.147 & 1.77 & 5.88 & 0 \\
\hline 9 & 6.03 & 2.45 & 4.239 & 2.16 & 2.37 & 1,85 \\
\hline 10 & 0.48 & 0.45 & 3.212 & 2.99 & 8.02 & 1.156 \\
\hline
\end{tabular}

O erro médio obtido entre o nosso sistema e o automático da Topcon foi de $1,653 \%$ em relação às medidas dos raios de curvatura e de $4,159 \%$ para o eixo do astigmatismo. Entre o nosso sistema e o manual da Baush-Lomb, foi de 2,363\% em relação às medidas dos raios de curvatura e de 7,346\% para o eixo do astigmatismo.

Com estes dados obtidos, várias conclusões sobre o sistema podem ser obtidas. Uma discussão geral sobre o sistema e as conclusões sobre os resultados obtidos estão a seguir. 


\section{Capítulo 10 - Discussĩes e Conclusões}

\section{Discussões e Conclusões}

Como amplamente discutido, os ceratômetros comercias se dividem em dois grupos principais: os manuais e os automáticos. Os manuais requerem uma atenção maior do clínico para projetar as miras para realizar as medidas, e uma relativa paciência para encontrar os eixos relacionados aos meridianos de maior e menor raios de curvatura corneano. As medidas são ainda mais penosas nos casos de astigmatismos regulares, onde se torna impossível focalizar o sistema que foi projetado para medidas de astigmatismos regulares apenas. Já os automáticos, são de fácil manuseio e estão geralmente adaptados em sistemas auto-refratores, o que faz com que o preço do equipamento seja alto.

Neste sentido o objetivo deste trabalho é poder combinar os benefícios dos sistemas comerciais, ou seja, fácil manuseio e baixo custo.

Os refratores comerciais que utilizamos para as comparações das medidas (auto-refrator RM-A7000 da Topcon e Keratometer - Model SO-10 (AMTEK) da Baush e Lomb) são amplamente difundidos e populares. Podemos observar que apresentam entre si um erro de 0,95087 \% para os raios de curvatura medidos e de $8,96692 \%$ para os eixos associados medidos.

O erro apresentado entre o nosso sistema desenvolvido e os comerciais está bastante próximo das discrepâncias de resultados que existem entre os ceratômetros já bem estabelecidos no mercado.

Assim, o sistema desenvolvido atingiu todos os objetivos iniciais propostos:

- Fácil manuseio: a Lâmpada de Fenda é fácil e amplamente manipulada pelos clínicos e de uso corriqueiro;

- Precisão: a precisão nas medidas de nosso sistema está dentro dos intervalos permitidos e de acordo com os sistemas comerciais existentes; 
- Baixo custo: a Lâmpada de Fenda é um equipamento básico disponível em todos os consultórios oftalmológicos e o custo do anel luminoso, detector CCD, placa de captura e micro computador são relativamente bem mais baratos do que os sistemas disponíveis no mercado.

O sistema desenvolvido estará sendo utilizado nos próximos meses no Hospital das Clínicas de Ribeirão Preto, onde deverá permanecer até que eventuais melhoramentos sejam necessários e realizados. Um dos melhoramentos a ser feito é a utilização de um filtro de infra-vermelho na projeção do anel, para o conforto do paciente, utilizando-se a propriedade do CCD ser um bom detector de infra-vermelho. 


\section{BIBLIOGRAFIA}

[1] Tipler, P.A., Física para Cientistas e Engenheiros, vol. 4, pg. 28-37, ed. Guanabara Koogan, 1995.

[2] Liliane Ventura S., Jarbas C.C. Neto, Ametropias Oculares, ver. Brasileira de Ensino de Física, v.17, n.4, p. 1-12, Dez. 1995.

[3] Schcolnicov, Bernado; Elementos de Óptica Oftálmica, $3^{\mathrm{a}}$ ed., Editorial Universitária, Paraguay, 1973.

[4] Alberto, Luis V. de Carvalho; Desenvolvimento de um Instrumento Para Medidas da Curvatura do Olho Durante Ato Cirúrgico, São Carlos 1996. Dissertação (Mestrado). Instituto de Física de São Carlos, Universidade de São Paulo.

[5] Duke-Elder, S. \& Abrams, D. System of Ophtalmology London, Henry Kimpton,1970. v.V, ch. 4-7.

[6] Albert, D.M., Edwards, D.D., The History of Ophtalmology, Blackwell Science, 1996.

[7] Ventura, L. \& Sousa, S.J.F. \& Castro, J.C. O astigmatismo e sua função associada, Ver. Fís. Aplic. Inst., Set. 95.

[8] Spalton, D.J ; Hitchings, R.A ; Hunter, P.A ; Ophtalmology, The Cornea, Series Ophtalmology an Illustrated Monograph Series, Merck Sharp \& Dohme International.

[9] Ventura, L. Sistema de Medidas Automáticas de Vícios de Refração Ocular, Tese de Doutoramento apresentada ao IFQSC - USP em 24/10/95.

[10] Charman, W.N. A Pioneering Instrument: the Collin's Eletronic Refrationometer. Ophthalmic Optician, v.16, p.345. 1976.

[11] Helmholt's Treatise on Physiological Optics, Dover Publications, Inc., vol. 1 e $2-301-334$.

[12] Duke-Elder, The Development Form and Function of The Visual Apparatus, Textbook of Ophtalmology, Vol I , The CV Mosby Co. 1940 pg.739.

[13] Río, E. Gil, Óptica Fisiológica Clínica Refración, Cuarta Edición, 228-243 Ediciones Toray, S.A. - Barcelona - España, 1981. 
[14] Hecht, E. Optics New York, Addison-Wesley Publishing Company, 1990. Second Edition.

[15] Tasman, W.; Leger, E.; Duane's Clinical Ophthalmology, Vol.1, 1995, Lippicott-Raven publisher, N.Y.

[16] Tasman, William, edward A. Jaeger, Duane's Clinical Ophtalmology, vol. 1, Lippncatt-Raven, 1995.

[17] Chiaradia C., Sistema de Medidas de Áreas de Úlceras de Córnea e Acompanhamento de Suas Evoluções Para ser Utilizado em Hospitais, Dissertação de Mestrado apresentado ao IFSC-USP,1998.

[18] Smith, George; Atchison David A , The Eye and Visual Optical Instruments, 1941, Cambridge University Press, pp.175.

[19] Jue, Bill and Maurice, David M.; The Mechanical Properties of the Rabbit and Human Cornea, J. Biomechanics, vol. 19, n. 10, pp 847-853, 1986.

[20] Mammone, R.J., Gersten, M., Gorley, D.J., Kaplin, R.S., Lubkin, V.L., 3D Corneal modeling System, IEEE Trans. Biomedical Eng., 19990; 37:66-73.

[21] Henderson, Ken; Database Developer's Guide with Delphi2, Borland Press, Sams Publishing, 1996.

[22] Salmone, T.U., Horner, D.G., Comparison of elevation, curvature, and power descriptors for corneal topographic, Opt. And Vision Scie, vol.72, n.11, pp.806-808, 1995.

[23] Ventura, L.; Messias, A.M.V; Souza, S.J.F ; Software para Sistema de Ceratometria Acoplado à Lâmpada de Fenda XXII ENCONTRO NACIONAL DE FÍSICA DA MATÉRIA CONDENSADA, 11 a 15 de Maio de 1999, Hotel Primus, São Lourenço (MG).

[24] House, P.H., Chauhan, B.C., Hollands, R.H., Calibration of the Terry Keratometer, Am. Journal of Ophtalmology, October 1998.

Site consultado na Internet: - http://members.aol.com/eyeknowwhy/ 


\section{APÊNDICE I- MIIOPIA E HIIPERMETROPIA ${ }^{[9],[15]}$}

Para que um objeto seja enxergado distintamente, sua imagem, formada na retina, deve ser nítida. Se todos os elementos do olho fossem rigidamente fixos em suas posições, apenas os objetos situados a uma certa distância formariam imagens nítidas na retina. Entretanto, o olho normal pode focalizar nitidamente objetos situados a qualquer distância, desde o infinito até cerca de $15 \mathrm{~cm}$ à sua frente. Isso se torna possível pela ação do cristalino e do músculo ciliar ao qual ele é ligado. Quando em repouso, o olho normal é focalizado no infinito, isto é, o segundo foco está sobre a retina. Quando se deseja ver um objeto mais próximo, o músculo ciliar contrai-se e o cristalino toma uma forma quase esférica. Esse processo é denominado acomodação visual.

A maior e a menor distâncias para as quais é possível a visão distinta são chamadas ponto remoto e ponto próximo do olho, respectivamente. O ponto remoto de um olho normal fica situado no infinito. A posição do ponto próximo depende, evidentemente, de quanto pode ser aumentada a curvatura do cristalino, mediante a acomodação. A variação da acomodação diminui gradualmente com a idade, à medida que o cristalino perde sua flexibilidade. Por esse motivo, o ponto próximo afasta-se gradualmente, à medida que se envelhece. Esse afastamento do ponto próximo com a idade é chamado presbitismo ou presbiopia, não devendo, entretanto, ser considerado um defeito de visão, já que se processa mais ou menos da mesma forma em todos os olhos normais.

\section{Ametropias Oculares}

Existem vários defeitos comuns de visão ${ }^{[4,22]}$ devidos unicamente a uma relação incorreta entre os diversos elementos constitutivos do globo ocular, 
considerado como sistema ótico. Em outras palavras, os erros refrativos oculares são devidos à desarmonia entre o sistema ótico e o comprimento axial do olho.

O olho emétrope (normal), quando em repouso (livre da acomodação visual), forma na retina a imagem de objetos situados no infinito, como mostrado na figura A1.1a.

Olho amétrope é aquele para o qual o ponto remoto não está situado no infinito. As duas formas mais simples de ametropia são a miopia (ou braquiometropia) e a hipermetropia. Esses dois defeitos estão ilustrados nas figuras A1.1b e A1.1c.

Na miopia, o globo ocular é muito alongado em relação ao poder de refração do sistema ótico e os raios originados de um objeto situado no infinito convergem a um plano anterior à retina. $\mathrm{O}$ objeto mais afastado, cuja imagem se forma na retina, não está situado no infinito ou, em outras palavras, o ponto remoto se encontra a uma distância finita. Por outro lado, para a acomodação normal, o ponto próximo de um olho míope fica mais próximo que o de uma pessoa com vista normal.

Na hipermetropia, o globo ocular é curto em relação ao poder de refração do sistema ótico; a imagem de um objeto situado no infinito se forma atrás da retina. Mediante a acomodação, os raios paralelos poderiam convergir na retina, mas, evidentemente, se a capacidade de acomodação for normal, o ponto próximo estará mais distante que o de um olho emétrope.

Os dois defeitos de visão citados são devidos a causas opostas. Na miopia, a convergência de um feixe de raios paralelos é demasiadamente grande de modo que a imagem se forma antes da retina; na hipermetropia, a convergência é insuficiente. Assim, miopia e hipermetropia são fenômenos relativos (um olho míope pode possuir dimensões axiais normais, porém com alto poder de convergência do sistema ótico, por exemplo). 




FiguraA1.1: Ametropias Oculares: (a) emetropia; (b) miopia; (c) hipermetropia.

Há também um outro tipo de ametropia, denominado afacia, que é a ausência do cristalino, tornando o olho extremamente hipermétrope.

O astigmatismo, por sua vez, é um defeito da visão geralmente devido à não esfericidade da superfície da córnea; o raio de curvatura dessa superfície não é o mesmo em todos os meridianos - assemelha-se a uma bola de futebol americano (elipsóide), onde os meridianos de maior e menor curvaturas estão a $90^{\circ}$. O astigmatismo faz com que seja impossível, por exemplo, focalizar simultaneamente as barras horizontais e verticais de uma janela.

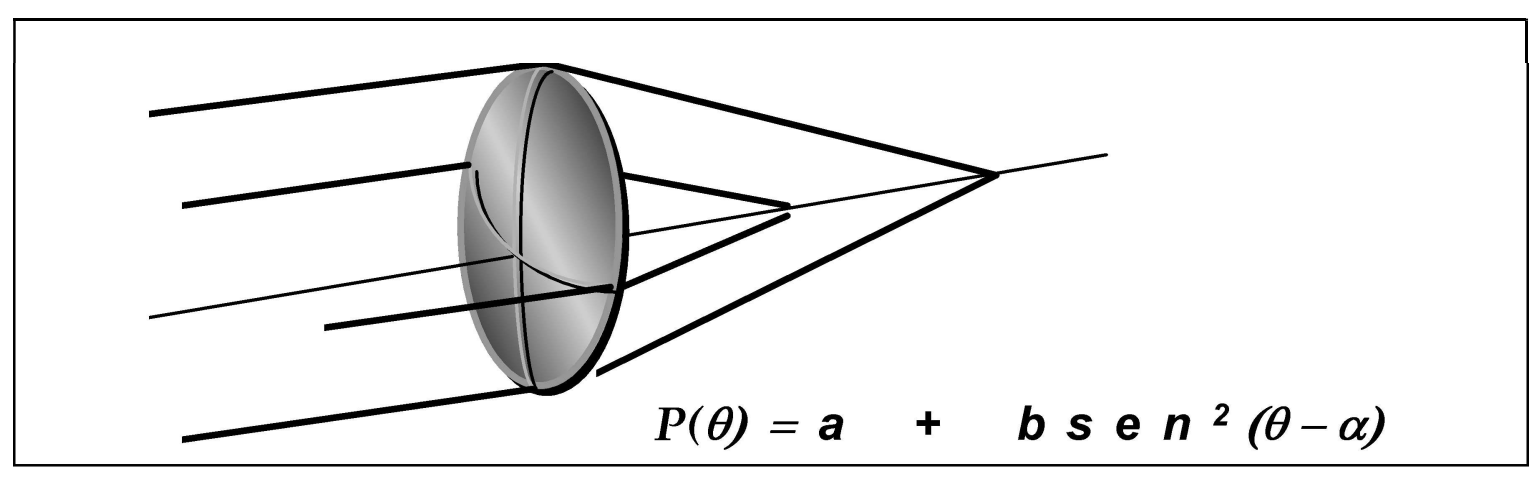

FiguraA1.2: Representação de quatro raios de luz incidentes num olho astigmático. 
Assim, o astigmatismo é a condição de refração onde feixes de luz, provenientes de uma fonte luminosa puntual situada no infinito, paralelamente incidentes em diferentes meridianos formam imagens em diferentes posições no eixo ótico (pontos focais diferentes para cada meridiano entre $0^{0}$ e $180^{\circ}$ - figura A1.2).

Miopia, hipermetropia e astigmatismo são discutidos a seguir detalhadamente.

\section{1 - HIPERMETROPIA ${ }^{[15]}$}

A hipermetropia é a forma de erro de refração na qual os raios luminosos paralelos são trazidos a um foco a uma certa distância atrás da retina, quando o olho encontra-se em repouso.

Houve época em que se aceitava que, na maioria dos casos de hipermetropia, o defeito fosse axial ${ }^{5}$ e persiste a crença de que, de fato, o olho hipermétrope tenha um eixo ântero-posterior mais curto do que o normal. Entretanto, é possível que o olho hipermétrope tenha um comprimento axial maior do que um olho míope, e ainda permanece alguma incerteza quanto à importância relativa do comprimento axial e o poder de refração como influências na causa da hipermetropia.

Via-de-regra, o grau de encurtamento não é grande e raramente excede $2 \mathrm{~mm}$. Cada milímetro de encurtamento representa aproximadamente 3 di de alteração na refração e, por conseguinte, uma hipermetropia de mais de 6di é incomum. Graus maiores, entretanto, ocorrem, como nos casos de até 24di sem qualquer outra anormalidade patológica ter sido verificada; e, certamente, nas aberrações patológicas do desenvolvimento, tais como na microftalmia, este valor pode ser ultrapassado.

A hipermetropia de curvatura ocorre quando a curvatura de qualquer das superfícies refringentes é excessivamente pequena. A córnea é a sede habitual da anomalia e pode mostrar-se achatada congenitamente (córnea plana) ou ser resultado de traumatismo ou doença. Um aumento de $1 \mathrm{~mm}$ no seu raio de curvatura produz uma hipermetropia de 6di. Nesses casos, entretanto, é raro que a curvatura 
permaneça esférica e será produzido quase que invariavelmente um astigmatismo. A hipermetropia de índice, como de hábito, manifesta-se na forma de uma diminuição na refringência eficaz do cristalino.

Uma luxação posterior do cristalino também causa hipermetropia, resultado de uma anomalia congênita ou de traumatismo ou doença; e a ausência do cristalino resulta também num grau acentuado de hipermetropia.

\section{2 - A ACOMODAÇÃO NA HIPERMETROPIA}

A hipermetropia ${ }^{[4],[22]}$ é subdividida em várias porções devido à influência interagente da acomodação visual nas medidas. Ela é subdividida em hipermetropia total (HT), composta pela hipermetropia latente (HL) e pela hipermetropia manifesta (HM); hipermetropia absoluta (HA); e hipermetropia facultativa $(H F)$.

A $H M$ é a hipermetropia que pode ser medida pelo médico sem a paralisação do músculo ciliar.

A contração do músculo ciliar no ato da acomodação aumenta o poder de refração do cristalino, de forma a corrigir um certo grau de hipermetropia. Normalmente, há um grau apreciável corrigido pela contração envolvida no tônus físiológico deste músculo e, conseqüentemente, o grau completo de hipermetropia só é revelado quando este músculo é paralisado pelo uso de uma droga como a atropina. Dizemos, assim, que o olho foi cicloplegiado. Desta forma, é possível medir-se a $H T$. A variação entre a $H M$ e a $H T$ é a $H L$.

Com a atuação total da acomodação visual, a pessoa hipermétrope é capaz de amenizar este erro de refração, porém, se o erro é grande e, independentemente do esforço da acomodação, o indivíduo não consegue ver o objeto de modo nítido, o grau de hipermetropia que ainda permanece sem correção e que não pode ser vencido pela acomodação é a $H A$. A quantidade de $H A$ corresponderá ao menor poder da lente corretora a ser prescrita ao paciente. 
Pórem, através de vários fatores, tais como, psíquicos, sociais, entre outros, o médico pode prescrever uma lente corretora cujo poder de refração está dentro do intervalo entre a $H A$ e a $H M$. Este intervalo corresponde à $H F$.

A seguir, um diagrama-exemplo poderá ajudar a compreender todas estas denominações.

No diagrama a seguir (A1-I), é exemplificado um paciente com HM (sem cicloplégico) de +4di e HT (com cicloplégico) de +6di, ou seja, com uma hipermetropia escondida de $+2 \mathrm{di}(\mathrm{HL})$.

A relação entre estas hipermetropias pode ser melhor compreendida segundo o método empregado para determiná-las clinicamente. Suponhamos que um hipermétrope não consiga ver um objeto distante nitidamente. São colocadas então lentes convexas de intensidade gradualmente crescente na frente de seus olhos, até que possa ver com clareza; neste momento, o cristalino e a sua acomodação encontram-se em atividade, de forma que, com a combinação de ambos, uma imagem distinta é observada. $\mathrm{O}$ grau de hipermetropia corrigida pela lente, ou seja, o grau que pelos seus esforços de acomodação não pode ser corrigido, é a hipermetropia absoluta, e é medida pela lente convexa mais fraca com que a acuidade visual máxima pode ser obtida. No caso do exemplo, a HA é de +1 di.

Avaliadas as HM e HA, através de uma análise subjetiva por parte do paciente, que se submeterá ao teste de várias lentes, cujos poderes de refração variam entre +1 di e +4 di $(\mathrm{HF})$, em nosso exemplo, e por análise psíquica e social feita pelo médico, é indicada a lente corretora ( $+3 \mathrm{di}$, no caso de nosso paciente do diagrama I). 
Diagrama A1-I

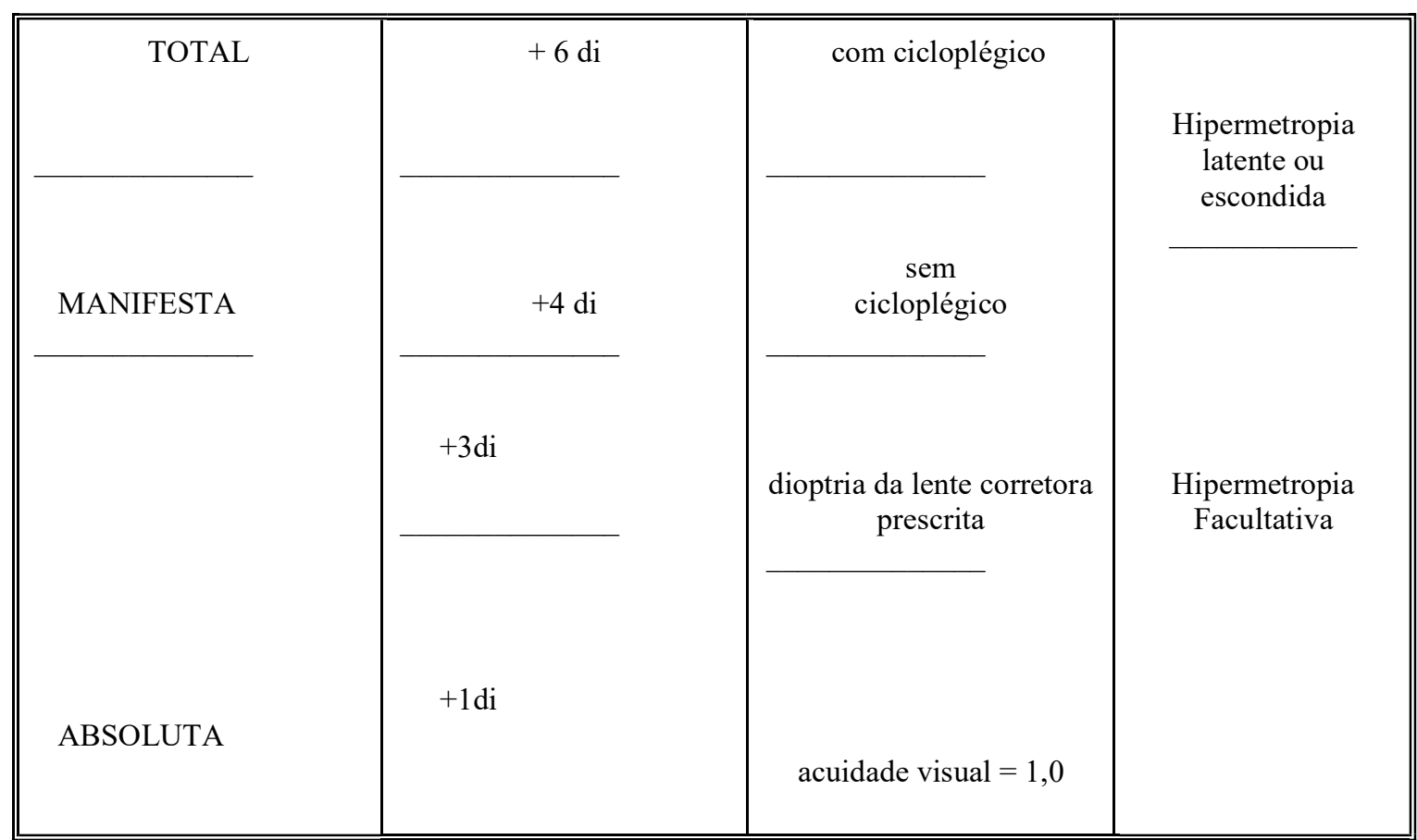

\section{$2.3-$ MIOPIA $^{[15]}$}

$\mathrm{Na}$ grande maioria dos casos, certamente nos graus mais intensos, a miopia é axial, isto é, deve-se a um aumento no diâmetro ântero-posterior do olho.

A miopia de curvatura pode estar associada a um aumento na curvatura da córnea ou de uma ou ambas as superfícies do cristalino. A maior curvatura da córnea ocorre não infreqüentemente, mas é, em geral, evidente como um erro astigmático e não esférico. Pequenos desvios do normal são comuns, visto que o raio da córnea normal varia dentro dos limites de 7,0 a 8,5mm, que podem ser de importância 
considerável, já que uma variação de $1,0 \mathrm{~mm}$ resulta numa modificação da refração de 6 di.

No que diz respeito à miopia de índice, uma modificação do índice de refração do aquoso ou do vítreo nunca é tão grande a ponto de exercer qualquer efeito apreciável. Por outro lado, modificações no cristalino podem certamente levar à miopia. É possível que uma diminuição do índice de refração do córtex desempenhe um papel na miopia diabética. Uma refringência aumentada do núcleo do cristalino é responsável pela miopia encontrada na catarata incipiente; de fato, o cristalino pode não se tornar opaco, mas o seu núcleo pode simplesmente tornar-se cada vez mais refringente, com o que se desenvolve lá uma miopia progressiva.

No recém-nascido, o olho normal é hipermétrope e, com o passar do tempo e o crescimento, isso tende a regredir. Em alguns casos permanece a hipermetropia; em outros, a emetropia é alcançada e o desenvolvimento torna-se estabilizado neste ponto; ao passo que, em alguns, a tendência evolui e resulta um grau maior ou menor de miopia. O período de crescimento é, portanto, o elemento crucial do ponto de vista da miopia.

\section{CONDIÇÃO ÓTICA}

No olho míope, os raios luminosos paralelos dirigem-se para um foco na frente da retina; a imagem sobre a retina compõe-se, portanto, de círculos de difusão formados pelo feixe divergente (figura A1.1b). Conclui-se que os objetos distantes não podem ser visualizados claramente; apenas os raios divergentes encontrar-se-ão na retina e, assim, a fim de ser visto claramente, um objeto qualquer deve ser trazido para perto do olho, de modo que os raios que dele emanam tornem-se suficientemente divergentes. O ponto remoto, no olho míope, está a uma distância finita - quanto maior o grau de miopia, menor a distância. Essa distância é, por 
conseguinte, uma medida do grau de miopia: se o ponto distante for de $1 \mathrm{~m}$ do olho, há -1di de miopia; se for de $2 \mathrm{~m},-0,5 \mathrm{di}$, etc.

\section{3 - Correção das Ametropias Através de Lentes}

As lentes convergentes e as divergentes ${ }^{[23]}$, como os próprios nomes dizem, têm a propriedade de convergirem e divergirem, respectivamente, a luz nelas incidentes, uma vez que a fonte de luz encontra-se numa região entre o infinito e sua distância focal.

Sendo assim, fica fácil deduzir que um olho hipermétrope necessita de lentes convergentes para sua correção, enquanto um olho míope, de lentes divergentes. Senão, vejamos:

Um olho hipermétrope não é apto, através da acomodação visual, a trazer à retina a imagem de um objeto num ponto próximo (embora, em alguns casos, seja capaz, gerando, contudo, sintomas que o incomodam) e tampouco, obter imagens nítidas de objetos situados no infinito sem ativar a acomodação visual. Assim, se os raios provenientes do infinito atingirem o olho com determinada convergência, a imagem deverá ser formada na retina. Isso é feito com lentes convergentes (veja figura A1.3a).

Para o míope ocorre o contrário, pois ele não consegue "relaxar" o cristalino o suficiente para que a imagem de um objeto situado no infinito caia sobre a retina. Como esta imagem está sempre localizada anteriormente à retina, os raios provenientes do infinito devem atingir o olho com uma divergência adequada para que a imagem forme-se na retina. Isso é feito com lentes divergentes (figura A1.3.b). Para corrigir estes erros refrativos através de lentes, a lente a ser utilizada deve ser tal que a sua distância focal coincida com o ponto remoto do olho em questão. Em 
outras palavras, a imagem que a lente corretora fornece de um objeto situado no infinito deve ser formada no ponto remoto do globo ocular, podendo, então, ser vista sem esforço. Dessa forma, o foco imagem $\mathbf{F}^{\prime}$ deve coincidir com o ponto remoto do olho.

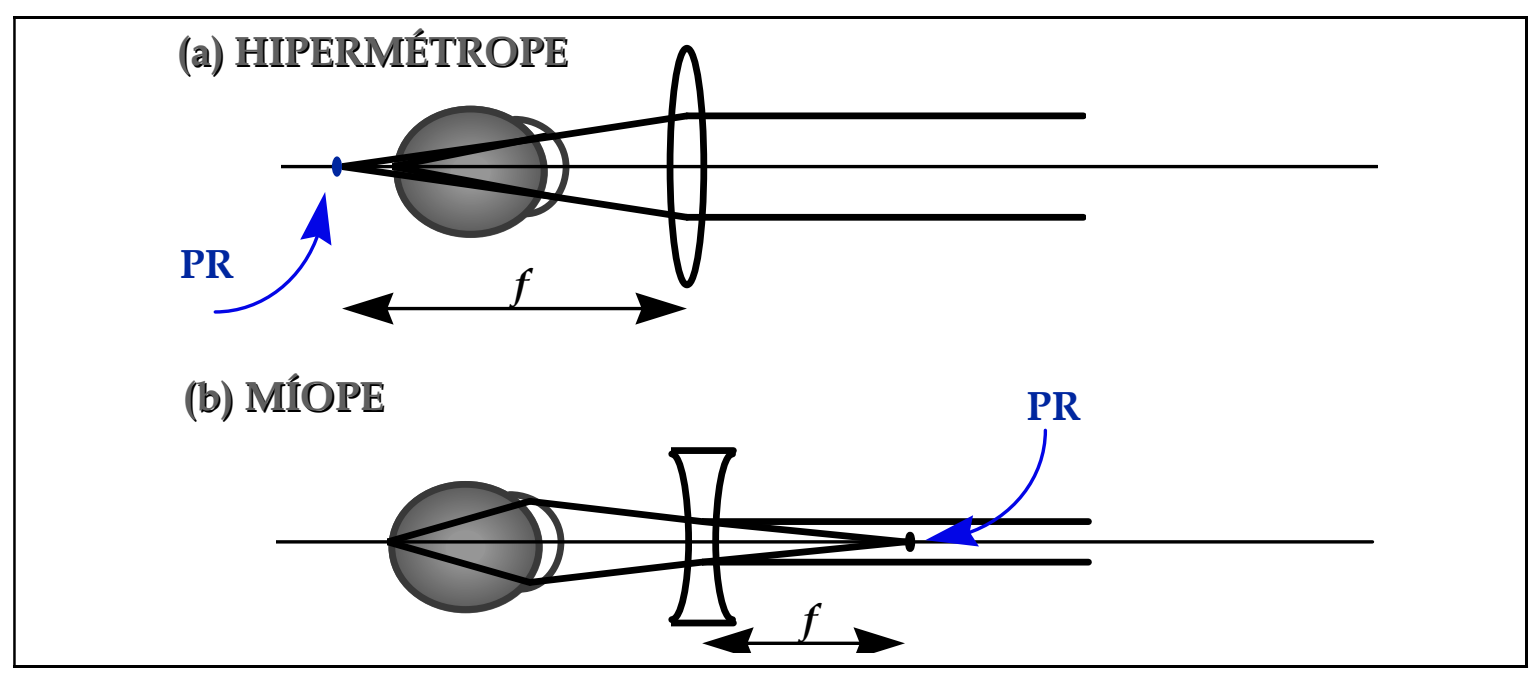

Figura A1.3: Correção através de lentes para a: (a) hipermetropia; (b) miopia. 
APÊNDICE II [3] - EQUAÇÃO DE MELHOR APROXIMAÇÃO PARA O MODELO ESFÉRICO

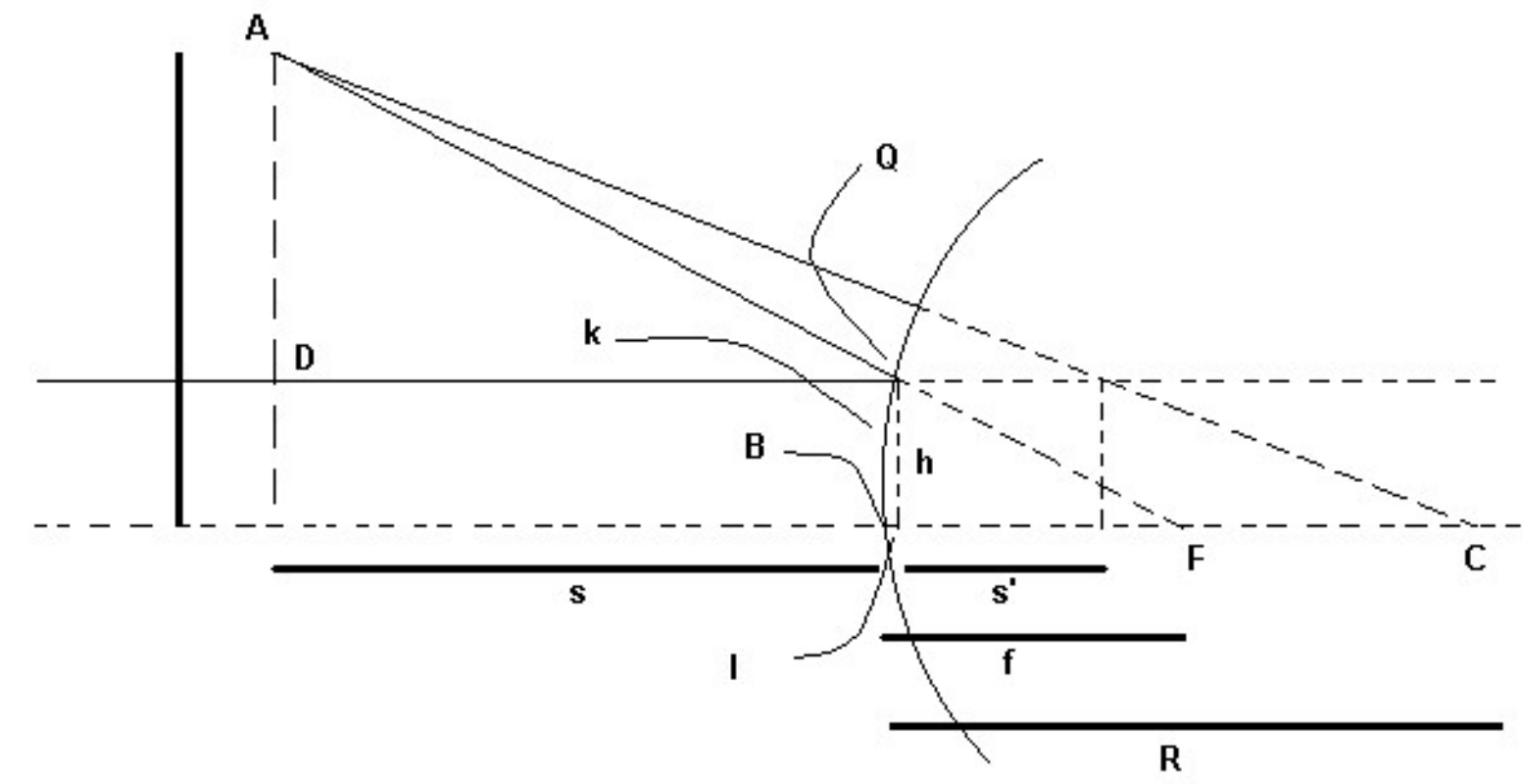

Fig.A2.1 - Esquematização do caminho óptico dos raios de luz para dedução da equação com aproximação "fina" para o modelo esférico.

Pela semelhança de triâgulos AQD e QPF podemos escrever:

$$
\frac{S+L}{f-l}=\frac{H-h}{h}
$$

e supondo que a Hipotenusa do triângulo QPF seja muito próxima da distância focal f r aplicando Pitágoras, teremos: 


$$
f^{2}=h^{2}+(f-l)^{2}
$$

isolando para 1, temos que:

$$
1=f-\left(f^{2}-h^{2}\right)^{1 / 2}
$$

Substituindo em e colocando f em evidência temos:

$$
\left(H^{2}-h^{2}\right) f^{2}-2 s h^{2} f-h^{2}\left(s^{2}+H^{2}\right)=0,
$$

a qual é uma equação de segundo grau em f, cuja raiz positiva é dada por

$$
f=\frac{2 S h^{2}+2 h H \sqrt{S^{2}+H^{2}-h^{2}}}{2\left(H^{2}-h^{2}\right)}
$$

Mas sabemos que para um espelho esférico $R=2 f$, o quê resulta na equação que utilizamos no modelo esférico para cálculos mais prercisos. 